PRACE GEOGRAFICZNE

zeszyt $155,2018,85-138$

doi: $10.4467 / 20833113$ PG.18.018.9541

Instytut Geografii i Gospodarki Przestrzennej UJ

Wydawnictwo Uniwersytetu Jagiellońskiego

\title{
PRZEBIEG TEMPERATURY ZIM NA OBSZARZE POLSKI W LATACH 1720-2015
}

\author{
Andrzej A. Marsz, Anna Styszyńska
}

\section{Course of winter temperatures in Poland in the years 1720-2015}

Abstract: The work discusses the air temperature course of winter periods (December-March) in Poland in the years 1720-2015. The analysis is carried out for area mean values calculated from 5 stations: Szczecin, Wrocław, Warsaw, Wilno and Lwów. The time series of the mean area winter temperature (hereinafter $\mathrm{PL}_{Z}$ ) consists of combined observational (140 years) and reconstructed (156 years) data. The $\mathrm{PL}_{\mathrm{Z}}$ reconstruction is based on independent variables, i.e. the values of the maximum area of the Baltic Sea covered with ice in a given ice season and the monthly temperatures in January and March from the Central England Temperature (CET) data set. The obtained correlations between the independent variables and the $\mathrm{PL}_{Z}$ are strong, highly significant and stable. A statistical analysis shows that the course of $\mathrm{PL}_{Z}$ is strongly correlated $(r=0.80, p<0.001)$ with the series of mean winter temperatures in Europe reconstructed by Luterbacher et al. (2006). In the analysed period of the years 1720-2015 the course of winter temperatures is non-stationary, there were periods of cooling and warming with different amplitude and duration. The variation range of $\mathrm{PL}_{Z}$ falls within the limits from -6.24 (in 1929) to $+3.35^{\circ} \mathrm{C}$ (in 1990). Winters with temperatures below $0^{\circ} \mathrm{C}$ account for $72 \%$ of winters in the examined period. Relatively mild winters dominated over Poland during the analysed period, with an average temperature ranging from $-1^{\circ} \mathrm{C}$ to $0^{\circ} \mathrm{C}$ and from $0^{\circ} \mathrm{C}$ to $1^{\circ} \mathrm{C}$, accounting for a total of $39.5 \%$ of all winters. The trend occurring in the $\mathrm{PL}_{Z}$ time series is very weak $\left(+0.0020( \pm 0.0012)^{\circ} \mathrm{C} \cdot \mathrm{year}^{-1} ; \mathrm{p}=0.103\right)$ and statistically insignificant, despite the fact that the highest $\mathrm{PL}_{Z}$ values in the entire analysed period occur after the year 1988 . The analyses show that the variability of $\mathrm{PL}_{Z}$ in the entire examined period does not go beyond the limits of natural variability and the recent increase in $\mathrm{PL}_{Z}$ is not unprecedented. Similarly strong temperature increases in winter temperatures were observed several times after the year 1720. The coldest winters occurred between the decades 1751-1760 and 1841-1850. 
The greatest variability of $\mathrm{PL}_{Z}$ is observed in the twentieth century, when the coldest (1961-1970, decade mean $\left.\mathrm{PL}_{Z}-2.253^{\circ} \mathrm{C}\right)$ and the warmest decades $\left(1991-2000, \mathrm{PL}_{Z}+0.020^{\circ} \mathrm{C}\right)$ occurred in the entire analysed period. The breakthrough in the course of $\mathrm{PL}_{Z}$, combined with the change in the thermal structure of winters, which can be identified with the end of the Little Ice Age, occurred gradually in the years 1858-1885 along with an increase in the intensity of the zone circulation. Changes in the solar constant and the frequency of volcanic eruptions did not affect the variability of winter temperatures.

Keywords: Winter temperatures, Poland, XVIII-XX centuries, temperature reconstruction, course and range of variation

Zarys treści: W pracy omówiono przebieg temperatury powietrza okresów zimowych (grudzień-marzec) w Polsce w latach 1720-2015. Analiza jest prowadzona dla wartości będących średnimi obszarowymi obliczonymi z 5 stacji: Szczecina, Wrocławia, Warszawy, Wilna i Lwowa. Szereg czasowy wartości średniej temperatury obszarowej zim (dalej $\mathrm{PL}_{z}$ ) stanowią połączone dane pomiarowe (140 lat) i rekonstruowane (156 lat). Rekonstrukcja $\mathrm{PL}_{z}$ oparta jest na zmiennych niezależnych: wartościach maksymalnej powierzchni zlodzonej Bałtyku w danym sezonie lodowym oraz na wartościach temperatury miesięcznej stycznia i marca ze zbioru Central England Temperature (CET). Uzyskane zależności między zmiennymi niezależnymi a $\mathrm{PL}_{z}$ są silne, wysoce istotne i stabilne. Analiza statystyczna wykazuje, że przebieg $\mathrm{PL}_{Z}$ jest silnie skorelowany $(r=0,80, p<0,001)$ z szeregiem średniej temperatury zim w Europie, rekonstruowanym przez Luterbachera i in. (2006). W rozpatrywanym okresie lat 1720-2015 przebieg temperatury zim jest niestacjonarny, występowały okresy ochłodzeń i ociepleń o różnej amplitudzie i czasie trwania. Zakres zmienności $\mathrm{PL}_{\mathrm{Z}}$ mieści się w granicach od $-6,24$ (rok 1929) do $+3,35^{\circ} \mathrm{C}$ (rok 1990). Zimy o temperaturze niższej od $0^{\circ} \mathrm{C}$ stanowią $72 \%$ zim w badanym okresie. W ciągu badanego wielolecia dominowały nad Polską zimy stosunkowo łagodne, o średniej temperaturze mieszczącej się w przedziale od $-1^{\circ} \mathrm{C}$ do $0^{\circ} \mathrm{C}$ i od $0^{\circ} \mathrm{C}$ do $1^{\circ} \mathrm{C}$, stanowiące łącznie 39,5\% wszystkich zim. Występujący w szeregu czasowym $\mathrm{PL}_{\mathrm{Z}}$ trend jest bardzo słaby $\left(+0,0020( \pm 0,0012)^{\circ} \mathrm{C} \cdot \mathrm{rok}^{-1} ; \mathrm{p}=0,103\right)$ i statystycznie nieistotny, mimo tego, że najwyższe wartości $\mathrm{PL}_{z}$ w całym badanym okresie występują po 1988 . Analizy wykazują, że zmienność $\mathrm{PL}_{z}$ w całym badanym okresie nie wykracza poza granice zmienności naturalnej, a wzrost $\mathrm{PL}_{Z}$ w ostatnim okresie nie jest bezprecedensowy, podobnie silne wzrosty temperatury zim miały kilkukrotnie miejsce po roku 1720 . Najchłodniejsze zimy wystąpiły między dekadami 1751-1760 a 1841-1850. Największą zmienność $\mathrm{PL}_{\mathrm{Z}}$ wykazuje w XX w., kiedy wystąpiły najchłodniejsza (1961-1970, średnia dekadowa $\left.\mathrm{PL}_{z}-2,253^{\circ} \mathrm{C}\right)$ i najcieplejsza dekada $\left(1991-2000, \mathrm{PL}_{Z}+0,020^{\circ} \mathrm{C}\right) \mathrm{w}$ całym badanym okresie. Przełom w przebiegu $\mathrm{PL}_{Z}$, połączony ze zmianą struktury termicznej zim, który można utożsamiać z końcem Małej Epoki Lodowej wystąpił stopniowo w latach 1858-1885, wraz ze wzrostem natężenia cyrkulacji strefowej. Zmiany stałej słonecznej i częstości wybuchów wulkanicznych nie wywierały wpływu na zmienność temperatury zim.

Stowa kluczowe: temperatura zim, Polska, XVIII-XX wiek, rekonstrukcja temperatury, przebieg i zakres zmienności 


\section{Sformułowanie zagadnienia}

Poznanie zachowania się zmian temperatury powietrza zachodzących w długich okresach jest istotne dla oceny charakteru i skali zachodzących współcześnie zmian klimatycznych. Ten czynnik zapewne spowodował, że zainteresowanie zmianami temperatury zachodzącymi w skali historycznej, rzędu stuleci i millenium, gwałtownie wzrosło w ostatnim dwudziesto-, trzydziestoleciu. Na podstawie różnych danych, przy wykorzystaniu zróżnicowanych metod, rekonstruowano przebiegi temperatury nad obszarem Europy (np. Luterbacher i in. 1999) i jej poszczególnymi częściami (np. Jevrejeva 2001; Tarand i Nordli 2001; Brazdil i in. 2005; Eriksson i in. 2007; Brazdil i Dobrovolny 2010; Klimienko i Solomina 2010; Niedźwiedź i in. 2015). Szereg rekonstrukcji zmian temperatury i opadów w Polsce, w różnych skalach czasowych, w licznych publikacjach samodzielnych i ze współautorami przedstawił Przybylak (Przybylak 2006, 2008, 2016; Przybylak i in. 2001, 2003, 2004, 2005, ..., 2014a i b), a także w Tatrach - Niedźwiedź (2004).

Dane instrumentalne, na których opierają się te rekonstrukcje są nieliczne, o różnym zasięgu regionalnym i obarczone nieznanymi błędami. Pomijając wykorzystanie danych będących interpretacjami klimatycznymi zapisów historycznych, większość rekonstrukcji temperatury powietrza wykorzystuje dendrochronologiczne dane proxy, te jednak charakteryzują warunki termiczne i opadowe panujące w ciepłej porze roku. Znaczną trudnością w interpretacji danych dendrologicznych jest oddzielenie sygnału temperatury od sygnału uwilgotnienia w okresie wegetacyjnym. To powoduje, że dla obszaru Europy, w tym Polski, poza nielicznymi pracami (np. Koslowski i Glaser 1995; Jevrejeva 2001; Eriksson i in. 2007) rekonstruowana temperatura w chłodnej porze roku szacowana jest z mniejszym stopniem pewności. Temperatura powietrza w okresie zimowym wykazuje znacznie większą skalę zmienności międzyrocznej od podobnej zmienności w pozostałych porach roku, a nad obszarem Polski w zasadniczym stopniu wpływa również na wartość temperatury rocznej.

Styszyńska (2010) wykazała istnienie związków między wartościami maksymalnej powierzchni pokrywy lodowej na Bałtyku w danym sezonie lodowym (Seinä i Palosuo 1996) a temperaturą powietrza w Polsce. Związki te są silne i wysoce istotne, zwłaszcza w miesiącach zimowych. Tym samym stwarza to możliwość rekonstrukcji temperatury powietrza nad Polską w zimach występujących w dłuższym okresie, sięgającym do 1720 r., czyli w całym okresie dla którego istnieją dane Seinä i Palosuo. Wartości maksymalnej powierzchni zlodzonej Bałtyku (MIE) nie były do tej pory wykorzystane do rekonstrukcji temperatury powietrza nad Polską, a wykorzystywano je tylko w niektórych rekonstrukcjach temperatury i warunków cyrkulacyjnych nad Bałtykiem (np. Tinz 1996; Omstedt i Chen 2001).

Zasadniczym celem tej pracy jest przedstawienie i analiza cech przebiegu temperatury powietrza nad Polską w sezonach zimowych w długim okresie, obejmującym 
lata 1720-2015. Jednym z najważniejszych etapów tej pracy jest rekonstrukcja temperatury zimy w tych latach, dla których brakuje pomiarów instrumentalnych. Dalszymi etapami są oceny charakteru przebiegu temperatury zimy i ich zróżnicowania w czasie, a także odniesienie się do przyczyn powodujących występujące zróżnicowanie przebiegu temperatury zimy w niemal 300-letnim okresie, obejmującym drugą połowę okresu Małej Epoki Lodowej (dalej MEL), okres przejścia od MEL do klimatu „współczesnego” i okres klimatu „współczesnego”, włącznie z jego ostatnią fazą - gwałtownego wzrostu temperatury zimy.

\section{Metoda}

Ze względu na to, że wyniki przeprowadzonych badań dają wyniki odbiegające od dość powszechnie przyjmowanych wyobrażeń i opinii na temat charakteru i skali zmian temperatury zimy w XVIII i XIX w. w Polsce, autorzy czują się w obowiązku przedstawić stosowaną w tej pracy metodykę rekonstrukcji średniej temperatury zimy w sposób bardziej szczegółowy, niż czyni się to zazwyczaj.

\section{Problem wyboru predyktorów do estymacji temperatury zimy}

Podstawowym predyktorem do rekonstrukcji temperatury zimy na obszarze Polski, przyjętym w tej pracy, jest maksymalna powierzchnia zlodzenia Bałtyku w danym sezonie lodowym (dalej skrót MIE - Maximum Ice Extent). Jest to predyktor proxy o charakterze hydro-klimatycznym. Jego rozdzielczość czasowa jest roczna, co umożliwia z taką samą rozdzielczością rekonstruować temperaturę powietrza, jaka wystąpiła w danej zimie.

Moment największej powierzchni zlodzenia na Bałtyku w danym sezonie lodowym występuje zazwyczaj w drugiej połowie lutego lub pierwszej połowie marca. Szereg czasowy maksymalnych powierzchni zlodzenia Bałtyku (tys. $\mathrm{km}^{2}$ ) w latach 1720-1962 został na podstawie różnorodnych danych archiwalnych i wcześniejszych opracowań skompilowany i doprowadzony do postaci homogenicznej przez Seinä i Palosuo w roku 1963 (publikacja w j. fińskim), a następnie wydłużony do roku 1965 i opublikowany w języku angielskim (Seinä i Palosuo 1996). Wartości MIE dla okresu 1966-2015 uzyskano z kolejnych rocznych raportów Fińskiego Instytutu Badan Morskich (Report Series of the Finnish Institute of Marine Research). Te ostatnie wartości MIE zostały opracowane dokładnie według metodyki opisanej przez Seinä i Palosuo (1963, 1966).

Wartość maksymalnej powierzchni zlodzenia Bałtyku (ryc. 1) jest silnie uzależniona od przebiegu temperatury powietrza w basenie Bałtyku w całym okresie późnej jesieni i zimy, poprzedzającej moment wystąpienia MIE. Szereg badaczy 


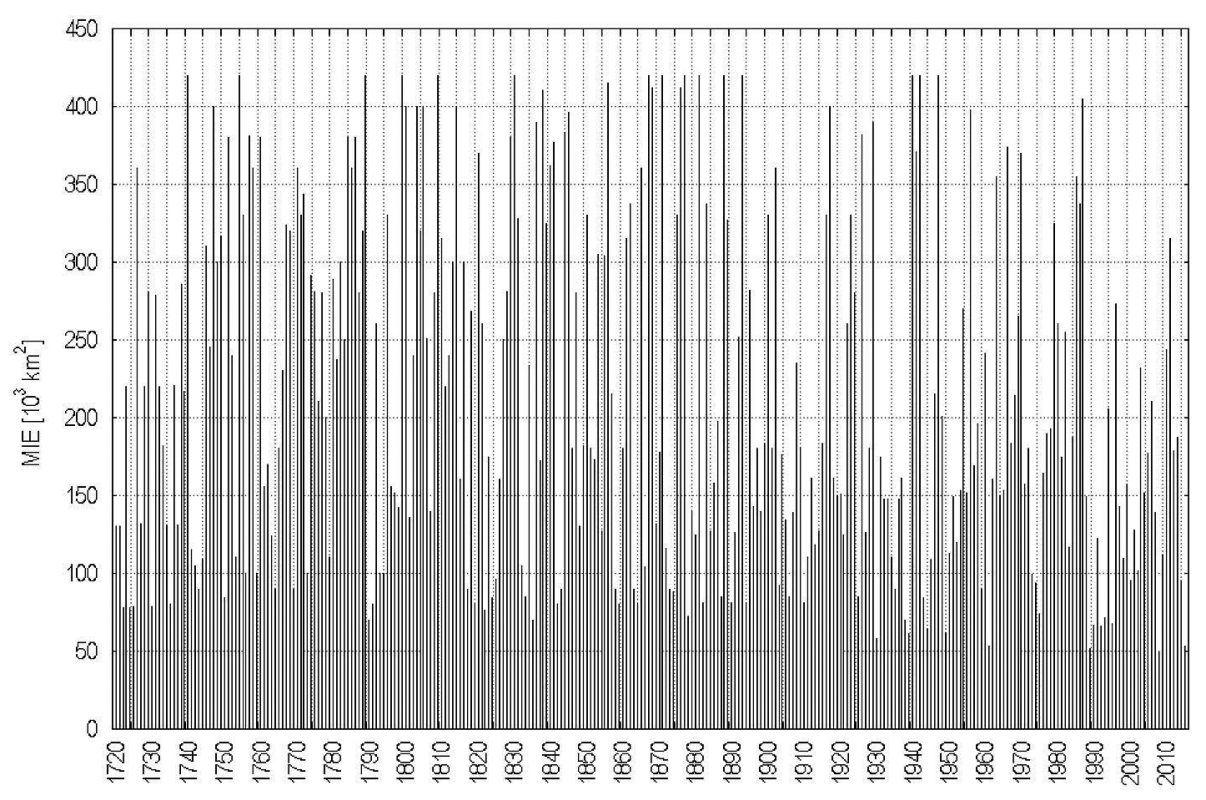

Ryc. 1. Przebieg wartości maksymalnej powierzchni zlodzenia Bałtyku (MIE) w latach 1720-2015 według danych Seinä i Palosuo (1996) oraz Fińskiego Instytutu Badań Morskich Fig. 1. The course of the Baltic maximum ice extent (MIE) in the years 1720-2015 according to the data of Seinä and Palosuo (1966) and the Finnish Institute of Marine Research

zwraca uwagę na ten fakt (np. Koslowski i Glaser 1995, 1999; Tinz 1996; Omstedt i Chen 2001; Vihma i Haapala 2009).

Aby doszło do utworzenia się pokrywy lodowej, temperatura powierzchni morza (SST - Sea Surface Temperature) musi osiągnąć temperaturę krzepnięcia, co oznacza, że nagromadzone wcześniej zasoby ciepła w wodach muszą zostać rozchodowane na wymianę z atmosferą. Ponieważ rozmiary strumieni ciepła z powierzchni morza do atmosfery uzależnione są od różnicy temperatury między powierzchnią wody a powietrzem, różnicy między maksymalną prężnością pary wodnej w temperaturze powierzchni morza a prężnością aktualną oraz prędkości wiatru, to tym szybciej dojdzie do wychłodzenia wody do punktu krzepnięcia, im wcześniej nastąpi spadek temperatury powietrza w basenie Bałtyku, im niższa będzie temperatura powietrza oraz im częściej nad Bałtyk będzie napływało suche i o niskiej temperaturze powietrze kontynentalne, a także im będzie większa prędkość wiatru. Z chwilą rozpoczęcia tworzenia się lodu proces rozwoju powierzchni zlodzonej będzie trwał tak długo, jak długo utrzymywać się będzie nad Bałtykiem lub jego częścią ujemna 
temperatura powietrza, a powierzchnia zlodzenia i grubość lodu będzie tym większa, im większa będzie wartość sumy stopniodni mrozu (sumy ujemnych wartości temperatury dobowej).

Po momencie osiągnięcia przez powierzchnię zlodzenia maksimum rozpoczyna się proces destrukcji pokrywy lodowej. Jego czas uzależniony jest głównie od sumy dopływu promieniowania krótkofalowego do powierzchni lodu i morza, przebiegu temperatury powietrza oraz od rozmiaru powierzchni i grubości pokrywy lodowej-im ta jest większa, tym większe ilości ciepła potrzebne są do jej ostatecznej likwidacji i tym samym moment całkowitego zaniku pokrywy lodowej się opóźnia. W latach, w których grubość lodów i powierzchnia zlodzenia jest duża, całkowity zanik lodów morskich na najdalej na północ położonych częściach Bałtyku następuje dopiero w połowie lub nawet w końcu czerwca (np. w roku 1985).

Rozkład przestrzenny temperatury powietrza w okresie zimowym nad basenem Bałtyku wykazuje silne zróżnicowanie. Najniższa temperatura powietrza występuje zazwyczaj na obszarze wschodniej i północnej części basenu Bałtyku (Zatoka Fińska, Morze Archipelagowe, Morze Bothnia i Zatoka Botnicka), tam też najwcześniej rozpoczyna się tworzenie pokrywy lodu morskiego. Ze względu na płytkość tych akwenów i w związku z tym niezbyt duże zasoby ciepła w wodach, pokrywa lodów morskich tworzy się na nich corocznie ${ }^{1}$. Nawet przy relatywnie wysokiej średniej temperaturze zimy nad obszarem środkowych i południowych części Bałtyku MIE osiąga rozmiar od 80 do około 120 tys. $\mathrm{km}^{2}$.

Zwiększona powierzchnia zlodzenia (120-200 tys. km²) występuje w sytuacji, gdy temperatura powietrza nad środkowymi partiami Bałtyku staje się bliższa przeciętnej i/lub gdy czas występowania ujemnych wartości temperatury powietrza ulega tam wydłużeniu. Tworzenie się pokrywy lodowej o powierzchni przekraczającej 250-300 tys. $\mathrm{km}^{2}$ wymaga dłuższego okresu wystąpienia ujemnej temperatury powietrza, znacznie niższej od przeciętnej, również nad obszarami Bałtyku Środkowego i Zachodniego, a do całkowitego zamarznięcia akwenu (400-420 tys. km²) również nad obszarem Bałtyku Południowego.

Ponieważ zmiany zimowego pola temperatury powietrza, wpływające na rozmiar MIE w danym roku, zachodzą nad całym obszarem wokółbałtyckim, między maksymalną powierzchnią zlodzenia Bałtyku, będącą funkcją rozkładu czasoprzestrzennego tego pola, a średnią miesięczną temperaturą nad Polską zachodzą korelacje ujemne zróżnicowanej siły. Korelacje istotne statystyczne występują od grudnia do kwietnia, a na większości polskich stacji - słabsze, ale istotne korelacje ( $\operatorname{rod}-0,26$ do -0,52) występują również ze znacznym opóźnieniem - w sierpniu. Wcześniejsze analizy

\footnotetext{
${ }^{1}$ Pomija się tutaj, na ogół płytkie, zatoki Morza Bałtyckiego (np. Zatokę Ryską) oraz zalewy przybrzeżne o ograniczonej możliwości wymiany wód z otwartymi wodami morza, które zamarzają niemal corocznie przy znacznie wyższej temperaturze powietrza.
} 
Tab. 1. Wartości współczynników korelacji między wartościami MIE a miesięczną i sezonową temperaturą powietrza $\left[{ }^{\circ} \mathrm{C}\right]$ w Koszalinie (KOSZ), Poznaniu (POZN), Warszawie (WARS), Wrocławiu (WROC) i Krakowie (KRAK). Okres korelacji 1850-2009 (150 lat). Istotne statystycznie wartości współczynników korelacji $(\mathrm{p}<0,05)$ oznaczone pogrubionym drukiem, wysoce istotne $(\mathrm{p}<0,001)$ - dodatkowo *

Table 1. Values of correlation coefficients between MIE values and monthly and seasonal air temperature $\left[{ }^{\circ} \mathrm{C}\right]$ in Koszalin (KOSZ), Poznań (POZN), Warszawa (WARS), Wrocław (WROC) and Kraków (KRAK). Correlation period 1850-2009 (150 years). Statistically significant values of correlation coefficients $(\mathrm{p}<0.05)$ marked in bold, highly significant $(\mathrm{p}<0.001)$ - additional (value)*

\begin{tabular}{|c|c|c|c|c|c|}
\hline Miesiąc - okres & KOSZ & POZN & WARS & WROC & KRAK \\
\hline XII & $-0,34^{*}$ & $-0,26^{*}$ & $-0,29 *$ & $-0,21$ & $-0,19$ \\
\hline I & $-0,57^{*}$ & $-0,53^{*}$ & $-0,54^{*}$ & $-0,51^{*}$ & $-0,45^{\star}$ \\
\hline II & $-0,58^{*}$ & $-0,50^{*}$ & $-0,51^{*}$ & $-0,46^{*}$ & $-0,40^{*}$ \\
\hline III & $-0,45^{*}$ & $-0,42^{*}$ & $-0,46^{*}$ & $-0,40^{*}$ & $-0,38^{*}$ \\
\hline IV & $-0,40^{*}$ & $-0,31^{*}$ & $-0,34^{*}$ & $-0,28^{*}$ & $-0,26^{*}$ \\
\hline V & $-0,13$ & $-0,05$ & $-0,08$ & $-0,05$ & $-0,08$ \\
\hline Zima klimatyczna (XII-II) & $-0,68^{*}$ & $-0,61^{*}$ & $-0,64^{*}$ & $-0,58^{*}$ & $-0,51^{*}$ \\
\hline Zima (XII-III) & $-0,70^{*}$ & $-0,64^{*}$ & $-0,67^{*}$ & $-0,61^{*}$ & $-0,54^{*}$ \\
\hline Wiosna klimatyczna (III-V) & $-0,49 *$ & $-0,41^{*}$ & $-0,46^{*}$ & $-0,40^{*}$ & $-0,38^{*}$ \\
\hline
\end{tabular}

Źródto: Styszyńska (2010); skrócone w stosunku do oryginału.

Source: Styszyńska (2010); short version of the original.

Styszyńskiej (2010) wskazują na dość poważne różnice przestrzenne w sile tych związków na obszarze Polski.

Najsilniejsze związki między MIE i temperaturą powietrza zachodzą nie w skali miesięcznej, ale w skali sezonowej, przy czym największą siłę wykazują zimą, rozumianą jako okres od grudnia do marca włącznie (tab. 1). Zwraca uwagę to, że mimo iż moment wystąpienia MIE przypada przeciętnie w drugiej połowie lutego lub w pierwszej dekadzie marca, to istotne korelacje MIE z miesięczną temperaturą powietrza w Polsce utrzymują się jeszcze w kwietniu. Takiego rodzaju charakter związków między MIE i temperaturą powietrza skłania do przyjęcia do rekonstrukcji „rozszerzonego” okresu zimy - od grudnia do marca włącznie (DJFM) - pozwoli to uwzględnić sytuację, w której wystąpiło przedłużenie okresu wystąpienia ujemnej miesięcznej temperatury powietrza również w marcu².

${ }^{2}$ Dalej, kiedy mowa o zimie, rozumie się pod tym mianem okres od grudnia do marca włącznie, a zima datowana jest na rok stycznia. 
W okresie zimy traktowanej jako okres od grudnia do marca włącznie zmienność MIE objaśnia od 49-55\% wariancji średniej temperatury tego okresu na północy Polski do 26-29\% na południu Polski.

Bardziej szczegółowa analiza związków między MIE i temperaturą powietrza w Polsce ujawnia jednak pewne problemy. Jak wiadomo, Bałtyk, z Kattegatem włącznie, ma skończoną powierzchnię - jest to 420 tys. $\mathrm{km}^{2}$. Analiza związków między MIE kształtującym się między 370 a 420 tys. km² i temperaturą zimy wykazuje, że w szeregu przypadków Bałtyk jest już całkowicie zamarznięty przy wyższej temperaturze zimy, a dalszy spadek temperatury nie pociąga za sobą, bo nie może, dalszego wzrostu powierzchni zlodzonej. Innymi słowy, od regionalnie zróżnicowanej pewnej temperatury granicznej ${ }^{3}$ dalszy spadek temperatury nie pociąga za sobą dalszego powiększania powierzchni zlodzonej. W związku z tym równanie regresji, w której MIE jest argumentem funkcji zimowej temperatury powietrza w Polsce, nie będzie w stanie realnie oszacować najniższych wartości średniej temperatury zimy - w szeregu przypadków estymowana temperatura zimy jest zawyżona.

Podobna sytuacja kształtuje się w przypadku minimalnych wartości MIE. Są to wartości w granicach od 81 do poniżej 50 tys. km² (kategoria „Zimy ekstremalnie łagodne" według klasyfikacji Seinä i Palosuo (1996)). Duża rozciągłość południkowa Bałtyku powoduje, że nawet w przypadku ekstremalnie wysokich średnich wartości temperatury zimy nad obszarem większej części obszarów wokółbałtyckich, w tym i Polski, maksymalna powierzchnia zlodzona nie była nigdy mniejsza niż 49 tys. $\mathrm{km}^{2}$ (rok 2008). Również i ten czynnik powoduje, że równanie regresji liniowej, w którym średnia temperatura zimy w Polsce jest funkcją MIE, nie jest w stanie prawidłowo oszacować wartości temperatury w przypadku niskich wartości MIE. Estymowana temperatura będzie systematycznie zaniżana w przypadku, gdy wartości MIE są równe, niższe niż 70-80 tys. $\mathrm{km}^{2}$. Takiego rodzaju kształtowanie się warunków brzegowych ${ }^{4}$ zmusza do poszukiwania dalszych zmiennych niezależnych, które pozwoliłyby na rekonstrukcję zimowej temperatury powietrza nad Polską, korygujących niedostatki predykcyjne MIE.

Próby przyjęcia szeregu rocznych wartości TSI (Total Solar Irradiance; Krivova i in. 2007; Balmaceda i in. 2007)5 jako kolejnego predyktora, nie dały pozytywnych rezultatów. Szeregi rocznych wartości TSI nie będąc istotnie skorelowane z temperaturą zimy na

\footnotetext{
${ }^{3}$ Analizę prowadzono dla różnych okresów, aby zbadać, czy związki są stabilne, i dla różnych stacji. Nie przytacza się tutaj tego obszernego materiału.

${ }^{4}$ Zakres zmienności średniej obszarowej temperatury zimy estymowanej wyłącznie z MIE zawiera się w granicach od $-4,16$ do $+0,96^{\circ} \mathrm{C}$. Wartości obserwowane wykazują znacznie większy przedział zmienności - od $-6,24$ do $+3,36^{\circ} \mathrm{C}$.

${ }^{5}$ Źródło danych: Total Solar Irradiance: http://lasp.colorado.edu/data/source/tsi_data/TSI_TIM_Reconstruction.txt . TSI oblicza się z szeregów liczb Wolfa, w związku z czym zmienność w szeregach TSI i liczb Wolfa (czy innych zestawień liczb plam słonecznych) jest identyczna. Nie zachodzi więc potrzeba rozważania wykorzystania jako predyktora szeregu chronologicznego liczb Wolfa.
} 
stacjach Polski (np. Warszawa, 1901-2000; $\mathrm{r}=0,10, \mathrm{p}=0,310$ ), nie objaśniają wiarygodnie, ani same, ani w połączeniu z MIE, zmienności temperatury zimy na stacjach Polski. Pozwala to wątpić w często formułowaną tezę o wymiernym bezpośrednim wpływie zmiennej aktywności Słońca na zmienność temperatury zimy, a tym samym temperatury rocznej w Polsce.

Poszukiwanie potencjalnych predyktorów o rozdzielczości rocznej, nieskorelowanych lub słabo skorelowanych z MIE, a skorelowanych z temperaturą zimy na stacjach polskich, pozwoliły rozważyć przyjęcie jako następnych predyktorów wartości miesięcznej temperatury powietrza z serii Central England Temperature: (dalej CET; Manley 1974; dane HadCET ze zbioru Met Office). Seria CET rozpoczyna się od roku 1659, co pozwala wykorzystać do rekonstrukcji temperatury zimy cały szereg wartości MIE, który rozpoczyna się od roku 1720. Mimo pewnych kontrowersji co do pełnej wiarygodności tej serii (patrz np. Parker i Horton 2005), jest ona powszechnie używana zarówno do rekonstrukcji warunków klimatycznych w Europie, jak i opisów zmian jej klimatu.

Korelacje między miesięcznymi wartościami CET z okresu chłodnego a średnią temperaturą zimy na 3 wybranych stacjach polskich oraz w Wilnie i Lwowie w stuleciu 1901-2000 zestawione są w tab. 2. Są to w większości przypadków korelacje wysoce istotne umiarkowanej siły, w których zmienność miesięcznych wartości CET objaśnia od 6-10 do 43-44\% wariancji średniej obszarowej temperatury zimy w Polsce. Analizy rozrzutu wykazują, że mimo istotnych statystycznie korelacji, w znacznym odsetku przypadków między temperaturą miesięczną z serii CET a temperaturą powietrza zimy na stacjach polskich występują poważne niezgodności.

Tab. 2. Wartości współczynników korelacji między średnią miesięczną temperaturą powietrza z serii Central England Temperature (HadCET) a średnią temperaturą zimy (12-03) na wybranych stacjach. Okres korelacji 1901-2000. Oznaczenia istotności - jak w tab. 1

Table 2. Values of correlation coefficients between the average monthly temperature of the Central England Temperature (HadCET) series and the average winter temperature (Dec-Mar) at selected stations. Correlation period 1901-2000. Significance markings as in Table 1

\begin{tabular}{|c|c|c|c|c|c|}
\hline Miesiąc & Szczecin 12-03 & Wrocław 12-03 & Warszawa 12-03 & Wilno 12-03 & Lwów 12-03 \\
\hline CET 12 & $0,35^{*}$ & $0,34^{*}$ & 0,31 & 0,26 & 0,24 \\
\hline CET 01 & $0,66^{*}$ & $0,66^{*}$ & $0,66^{*}$ & $0,63^{*}$ & $0,57^{*}$ \\
\hline CET 02 & $0,63^{*}$ & $0,62^{*}$ & $0,60^{*}$ & $0,57^{*}$ & $0,52^{*}$ \\
\hline CET 03 & $0,53^{*}$ & $0,48^{*}$ & $0,47^{*}$ & $0,45^{*}$ & $0,41^{*}$ \\
\hline CET 04 & 0,07 & 0,05 & 0,07 & 0,09 & 0,04 \\
\hline
\end{tabular}


Wskazuje to, że tylko w części sezonów zimowych związki między przebiegiem temperatury powietrza nad Polską są bardziej ściśle powiązane z przebiegiem temperatury nad Wyspami Brytyjskimi. Uproszczona analiza wielowymiarowa przeprowadzona dla okresu 1901-2000 wykazuje, że dzieje się tak w okresach zimowych, w których całości lub większej ich części zaznacza się dominacja cyrkulacji zachodniej. Są to sytuacje, w których maksymalna powierzchnia zlodzenia Bałtyku jest mniejsza od średniej lub mała - w skrajnych przypadkach - ekstremalnie mała. Odpowiada to tym przypadkom, w których prawidłowe oszacowanie temperatury zimy tylko ze zmienności MIE, ze względu na jej małe wartości, nie jest możliwe. Podobnie, niskie wartości CET, razem z MIE, wyraźnie korygują in minus, w stosunku do obliczanych tylko z MIE, dolne, najniższe oszacowane wartości średniej temperatury zimy w Polsce.

\section{Średnia „obszarowa” temperatura powietrza w okresie zimy w Polsce}

Kalibracja związków między predyktorami i temperaturą powietrza nad jakimś obszarem, jeśli długość szeregów predyktorów jest znacznie dłuższa od serii pomiarów temperatury, jest tym bardziej wiarygodna, im dłuższe są serie pomiarów temperatury. Długie serie pomiarów temperatury powietrza na obszarze Polski są nieliczne. Związki między predyktorami i seriami pomiaru temperatury na poszczególnych stacjach, w zależności od ich położenia, wykazują spore różnice. Aby zgeneralizować te różnice, postanowiono posłużyć się średnią „obszarową” z 5 stacji, mających najdłuższe serie obserwacyjne i jednocześnie tak rozmieszczonych, aby można było uznać, że obliczona średnia jest reprezentatywna dla całego obszaru Polski. Takie działanie jest w pełni uzasadnione w świetle wyników wcześniejszych badań wykazujących, że przebieg miesięcznej, sezonowej i rocznej temperatury powietrza na stacjach polskich wykazuje bardzo silne skorelowanie (np. Kożuchowski i Żmudzka 2003; Kożuchowski 2011). Stacjami tymi były: Szczecin, Wrocław, Warszawa, Wilno i Lwów.

Szereg miesięcznych wartości temperatury Warszawy z lat 1779-1985 pochodzi z pracy K. Kożuchowskiego (1990), część do roku 2015 według danych IMGW ze stacji Warszawa-Okęcie. Ten szereg przyjęto jako wyjściowy, gdyż nie zostały do niego wprowadzone poprawki. Szereg warszawski opracowany i poddany rekonstrukcji oraz homogenizacji przez H. Lorenc (2000) w poszczególnych jego kilkunastoletnich fragmentach, zwłaszcza w XVIII i XIX w., znacznie odbiega od zmienności MIE. Na podobne problemy z szeregiem opracowanym przez H. Lorenc (2000) zwracają również uwagę Przybylak i in. (2004). Dane ze stacji Wrocław (1791-2007) zaczerpnięto z opracowania K. i T. Bryś (2010). Dane ze stacji Szczecin z lat 1836-1868 oraz 1881-1944 pochodzą z materiałów archiwalnych DWD (Deutscher Wetterdienst). Szeregi danych z Wrocławia i Szczecina do 2015 r. uzupełniono danymi IMGW. Miesięczne 
wartości temperatury ze stacji Wilno (1777-2015) oraz Lwów (1824-1841, 1850-1857, 1882-2015) pochodzą ze zbiorów Met Office Hadley Centre (CRUTEM.4.5.; Osborn i Jones 2014).

Z szeregów temperatury miesięcznej na każdej z tych stacji utworzono średnie z okresu od grudnia do marca włącznie, traktując te wartości jako „średnią temperaturę zimy”. Następnie z tak obliczonych wartości dla 5 stacji obliczono „średnią obszarową" (oznaczenie $\mathrm{PL}_{\mathrm{zO}}$ ). Ponieważ na wymienionych stacjach w różnych, niejednoczesnych okresach występowały przerwy w obserwacjach, ostatecznie uzyskano 140 wartości średnich obszarowych temperatury zimy dla lat: 1837-1841, 1851-1857, 1883-1894, 1896, 1898-1915, 1918-1939 i 1941-2015. Szereg chronologiczny tych wartości potraktowano jako „masyw danych” zmiennych zależnych i wykorzystano go następnie do kalibracji równania regresji wielokrotnej, charakteryzującego związki między $\mathrm{PL}_{z O}$ a predyktorami, pozwalającego następnie na rekonstrukcję średniej temperatury zimy nad obszarem Polski.

Tak obliczone średnie obszarowe zimy $\left(\mathrm{PL}_{\mathrm{ZO}}\right)$ są bardzo silnie i wysoce istotnie skorelowane z podobnie obliczoną temperaturą zimy na wszystkich stacjach Polski w różnych, dłuższych i krótszych okresach. Przykładowo, w okresie 1931-1960 współczynniki korelacji między średnią temperaturą zimy na stacjach, dla których dane są zestawione w „Atlasie klimatycznym Polski” (1979), a tak obliczoną średnią obszarową mieszczą się w granicach od 0,94 do 0,99 , jedynie na stacjach górskich i wysoko położonych są niższe (np. Śnieżka - r = 0,79, Zakopane - r = 0,84). W umownym „centrum” Polski, za jakie można przyjąć Łódź, temperatura zimy jest równa $1,03( \pm 0,03)$ średniej obszarowej $\left(\mathrm{R}=0,98\right.$, adj. $\left.\mathrm{R}^{2}=0,97, \mathrm{~F}(1,28)=887\right)$, a błąd standardowy oszacowania temperatury zimy w Łodzi ze średniej obszarowej temperatury zimy $\left(\mathrm{PL}_{\mathrm{zO}}\right) \mathrm{w}$ tym okresie jest równy $\pm 0,38^{\circ} \mathrm{C}$.

\section{Metoda rekonstrukcji i szereg czasowy średniej temperatury zimy 1720-2015}

Rekonstruowane i obserwowane wartości temperatury zimy tworzące szereg czasowy przedstawiono w stopniach Celsjusza, nie zaś w postaci anomalii temperatury. Postanowiono również nie dokonywać „klasyfikacji” zim według odchyleń standardowych, ani też żadnych, w ten czy inny sposób modyfikowanych progów. Średnia temperatura zimy stanowi miarę obiektywną i nie zależy od subiektywnie dobranego okresu, względem którego średniej oblicza się anomalie czy też przeprowadza standaryzację. Stosowane dalej określenia „zima ciepła” i „zima chłodna” oznaczają jedynie to, że dana zima ma średnią temperaturę obszarową równą $0^{\circ} \mathrm{C}$, bądź dodatnią („ciepła”), bądź ujemną („,chłodna”). Innym używanym w treści określeniom zim nie przydaje się zdefiniowanych, ścisłych znaczeń, z wyjątkiem tych, które objaśnia się dalej bezpośrednio w tekście pracy. 
Wybór predyktorów do rekonstrukcji średniej obszarowej temperatury zimy przeprowadzono w pierwszym etapie metodą regresji wielokrotnej „w przód”, wstawiając jako szereg zmiennych zależnych (objaśnianych) średnią obszarową temperaturę zimy w Polsce $\left(\mathrm{PL}_{z O}\right)$, a jako zmienne niezależne (objaśniające) odpowiednie szeregi MIE oraz miesięcznych wartości temperatury centralnej Anglii z grudnia, stycznia, lutego i marca (oznaczenia $\mathrm{CET}_{12}, \mathrm{CET}_{01}, \mathrm{CET}_{02}, \mathrm{CET}_{03}$ ). Procedura obliczeniowa wyeliminowała z grupy zmiennych niezależnych (objaśniających) CET $_{12}$ i CET $_{02}$, gdyż ich znaczenie dla objaśnienia wariancji $\mathrm{PL}_{z O}$ było niższe od założonego arbitralnie progu tolerancji $(0,02)$. W rezultacie, do wykorzystywanego dalej równania regresji wielokrotnej, będącej „równaniem przejścia”, weszły trzy zmienne objaśniające (niezależne): MIE, CET $_{01}$ i CET $_{03}$. Estymacja parametrów równania regresji wielokrotnej dała następujące rezultaty (wartości parametrów podaje się ze zwiększoną dokładnością):

$$
\begin{aligned}
\mathrm{PL}_{\mathrm{ZO}}=-2,4564( \pm 05487) & -0,0092( \pm 0,0010) \cdot \mathrm{MIE}+0,4066( \pm 0,0629) \cdot \mathrm{CET}_{01}+ \\
& +0,2821( \pm 0,0621) \cdot \mathrm{CET}_{03}
\end{aligned}
$$

Charakterystyka statystyczna tej zależności jest następująca: R (współczynnik korelacji regresji wielokrotnej) $=0,8365$, adj. $R^{2}$ (poprawiony na liczbę stopni swobody współczynnik determinacji) = 0,6932, test Fishera z określonymi liczbami swobody $\mathrm{F}(3,136)=105,7$, prawdopodobieństwo przypadkowego uzyskania takiego wyniku $\mathrm{p}<<0,001$. Rozkład reszt jest normalny, a wartości reszt i usuniętych reszt są ściśle związane liniowo. Oszacowanie wartości wszystkich współczynników regresji i wyrazu wolnego jest wysoce istotne ( $\mathrm{p}<<0,001$; test Studenta).

W równaniu zmienność MIE objaśnia 55,03\% wariancji $\mathrm{PL}_{\mathrm{zO}}$ w szeregu liczącym 140 przypadków, a zmienność CET i CET $_{03}$ odpowiednio 10,40 i 4,55\%. Błąd standardowy estymacji (BSE) wartości $\mathrm{PL}_{z O}$ przez równanie wynosi $\pm 1,0620^{\circ} \mathrm{C}$. Wykres rozrzutu wartości przewidywanych $\left(\mathrm{PL}_{\mathrm{zOB}}\right)$ versus wartości obserwowanych przedstawia ryc. 2. Jak widać z tej ryciny, regresja ogranicza nieco estymowane wartości $\mathrm{PL}_{\mathrm{zOB}}$ względem rzeczywistych (obserwowanych) na obu krańcach zakresu zmienności. Takie ograniczenie amplitudy zmienności jest immanentną cechą odtwarzania zbioru wartości za pomocą regresji.

Wobec tego, że szereg czasowy MIE nie jest stacjonarny (ryc. 1), gdyż wyraźnie zaznacza się w nim długookresowa zmienność oraz statystycznie istotny trend ujemny $\left(-0,229( \pm 0,076)\right.$ tys. $\left.\mathrm{km}^{2} \cdot \mathrm{rok}^{-1}\right)$, powstaje kwestia stabilności oszacowanych współczynników regresji równania. Stabilność współczynników regresji zbadano, dzieląc dane $\mathrm{PL}_{\mathrm{zO}}$ ze stulecia 1901-2000 na dwie wyraźnie różne pod względem przebiegu części: lata 1901-1950 (47 przypadków, brak danych PL $_{z O}$ w latach 1916, 1917 i 1940 - przerwy wojenne) i 1951-2000 (50 przypadków), a następnie dla każdego z tych okresów szacowano odrębnie parametry równania regresji, wraz z oceną ich 


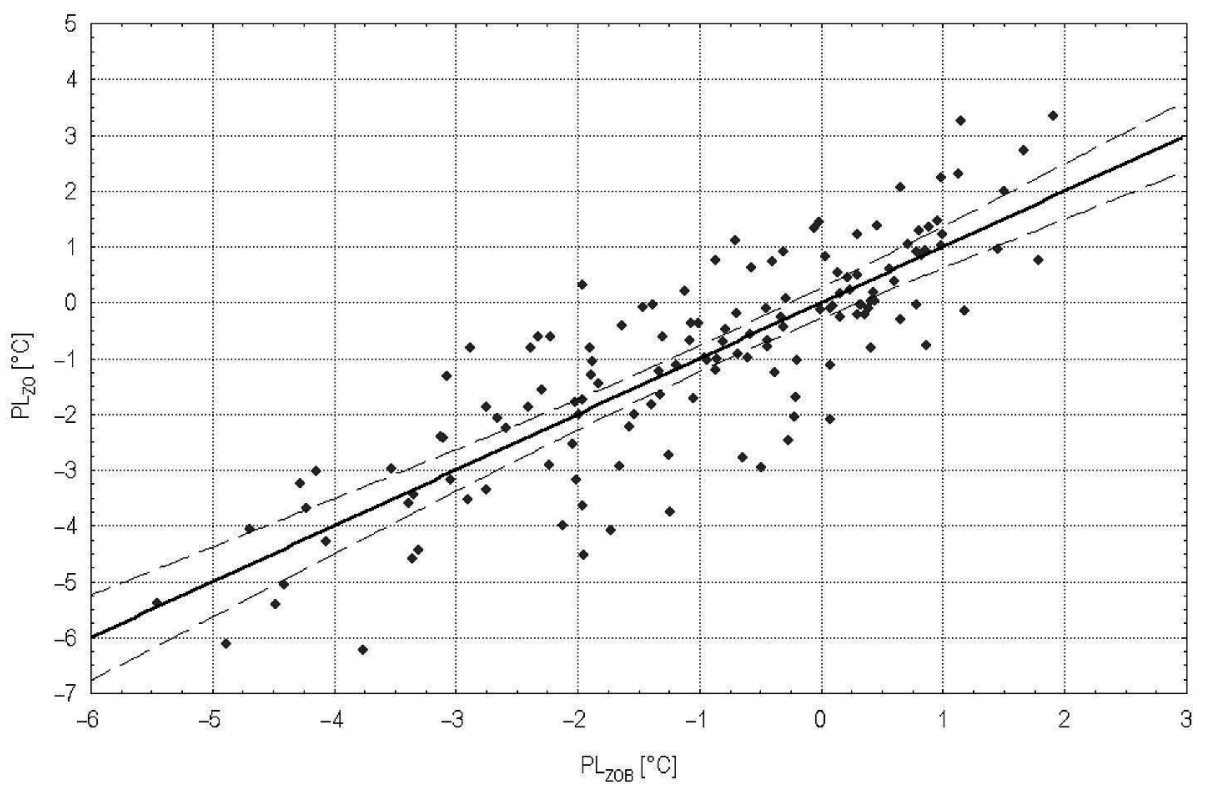

Ryc. 2. Wartości średniej obszarowej temperatury zimy (12-03; $\mathrm{PL}_{\mathrm{ZOB}}-$ wartości obliczone) oszacowane za pomocą równania względem obserwowanych $\left(\mathrm{PL}_{\mathrm{zO}}\right)$. Linie przerywane $-95 \%$ przedział ufności

Fig. 2. Values of the mean area winter temperature (Dec-Mar, $\mathrm{PL}_{\mathrm{ZOB}}$ - predicted values) estimated with Equation in relation to the observed values $\left(\mathrm{PL}_{\mathrm{ZO}}\right)$. Dashed lines $-95 \%$ confidence interval

błędów standardowych (tab. 3). Oba równania okazały się być wysoce istotne statystycznie, podobnie wysoce istotne są wszystkie parametry obu równań. Oszacowane prawdziwe zakresy parametrów równań (wyrazy wolne, współczynniki regresji tab. 3) wykazują, że zaznaczające się różnice między parametrami obu równań są statystycznie nieistotne, a oszacowane parametry równania mieszczą się w granicach niepewności estymacji parametrów równań dla obu krótszych okresów.

Wykazuje to, że równanie jest stabilne, co pozwala przyjąć je do rekonstrukcji średnich obszarowych wartości temperatury zimy (oznaczenie $\mathrm{PL}_{\mathrm{ZR}}$; zima rekonstruowana), ze wszystkimi wcześniej podniesionymi zastrzeżeniami.

Jakość rekonstrukcji wykorzystującej równanie wobec dość dużego błędu standardowego $\left( \pm 1,06^{\circ} \mathrm{C}\right)$ estymowanych wartości $\mathrm{PL}_{Z \mathrm{R}}$ jest trudna do jednoznacznej oceny. Porównanie krótkiej serii obserwacyjnej z lat 1781-1792 z Żagania, opracowanej przez Przybylaka, Pospieszyńską i in. (2014b) ze zrekonstruowanymi dla 
Tab. 3. Średnia obszarowa temperatura zimy w Polsce ( $\left.\mathrm{PL}_{\mathrm{ZO}}\right)$ w okresie 1901-1950 i 1951-2000, jej odchylenia standardowe oraz estymowane parametry równań regresji wielokrotnej dla każdego z okresów z ich błędami standardowymi (w nawiasach), a także prawdziwe zakresy zmienności parametrów (szacowana wartość parametru \pm błąd standardowy szacunku)

Table 3. Mean area winter temperature in Poland $\left(\mathrm{PL}_{\mathrm{ZO}}\right)$ in the period 1901-1950 and 1951-2000, its standard deviations and estimated parameters of multiple regression equations for each period with their standard errors (in brackets), as well as the real limits of parameter variability (estimated value of parameter \pm standard error of the estimate)

\begin{tabular}{|c|c|c|c|c|c|c|c|}
\hline \multirow{3}{*}{ Okres } & \multirow{3}{*}{$\begin{array}{c}\text { Liczba } \\
\text { przypadków }\end{array}$} & \multirow{3}{*}{$\begin{array}{l}\text { Średnia } \\
\mathrm{PL}_{z 0}\left({ }^{\circ} \mathrm{C}\right)\end{array}$} & \multirow{3}{*}{$\begin{array}{c}\text { Odchylenie } \\
\text { standardowe } \\
\mathrm{PL}_{\mathrm{zo}}\end{array}$} & \multicolumn{4}{|c|}{ Estymowane parametry równań } \\
\hline & & & & \multirow{2}{*}{$\begin{array}{c}\text { A } \\
\text { (wyraz wolny) }\end{array}$} & \multicolumn{3}{|c|}{ Współczynniki regresji } \\
\hline & & & & & $\begin{array}{c}b \\
\text { (przed MIE) }\end{array}$ & $\begin{array}{c}\mathrm{C} \\
\text { (przed CET } \\
01\end{array}$ & $\begin{array}{c}d \\
\text { (przed CET }\end{array}$ \\
\hline $1901-1950$ & 47 & $-0,900$ & 1,741 & $\begin{array}{c}-2,798 \\
( \pm 1,047)\end{array}$ & $\begin{array}{c}-0,0085 \\
( \pm 0,0018)\end{array}$ & $\begin{array}{c}0,3537 \\
( \pm 0,1265)\end{array}$ & $\begin{array}{c}0,3369 \\
( \pm 0,1261)\end{array}$ \\
\hline $1951-2000$ & 50 & $-0,916$ & 2,086 & $\begin{array}{c}-2,983 \\
( \pm 0,989)\end{array}$ & $\begin{array}{c}-0,0105 \\
( \pm 0,0019)\end{array}$ & $\begin{array}{c}0,4473 \\
( \pm 0,1021)\end{array}$ & $\begin{array}{c}0,3508 \\
( \pm 0,1003)\end{array}$ \\
\hline \multicolumn{8}{|c|}{ Prawdziwe zakresy zmienności parametrów } \\
\hline $1901-1950$ & - & - & - & $\begin{array}{c}-3,845 \\
\text { do }-1,751\end{array}$ & $\begin{array}{c}-0,0103 \\
\text { do }-0,0067\end{array}$ & $\begin{array}{c}0,2272 \\
\text { do } 0,4802\end{array}$ & $\begin{array}{c}0,2108 \\
\text { do } 0,4630\end{array}$ \\
\hline $1951-2000$ & - & - & - & $\begin{array}{c}-3,972 \\
\text { do }-1,994\end{array}$ & $\begin{array}{c}-0,0124 \\
\text { do }-0,0086\end{array}$ & $\begin{array}{c}0,3452 \\
\text { do } 0,5494\end{array}$ & $\begin{array}{c}0,2505 \\
\text { do } 0,4511\end{array}$ \\
\hline
\end{tabular}

tego samego okresu wartościami $\mathrm{PL}_{\mathrm{ZR}}$ wskazuje nadspodziewanie dobrą zgodność (ryc. 3) obu przebiegów. Wartość współczynnika korelacji jest równa 0,91 ( $\mathrm{n}=12$, $\mathrm{p}<<0,001$ ), mimo tego, że koreluje się tutaj temperaturę zimy traktowanej jako okres od grudnia do lutego (Przybylak i in. 2014b) z temperaturą zimy szacowanej jako okres od grudnia do marca włącznie $\left(\mathrm{PL}_{\mathrm{ZR}}\right)$. Jeśli pominie się różnice wartości między obserwowaną temperaturą w Żaganiu a temperaturą estymowaną, zauważa się prawidłowe odtwarzanie przez $\mathrm{PL}_{\mathrm{ZR}}$ cech przebiegu zmienności temperatury - zgodność momentów spadków i kulminacji w szeregu rekonstruowanym i obserwowanym.

Porównanie zrekonstruowanej obszarowej temperatury zimy nad Polską $\left(\mathrm{PL}_{\mathrm{ZR}}\right)$ z różnej długości fragmentami szeregu średniej temperatury zimy w Europie, będącej rekonstrukcją Luterbachera i in. (2006), wykazuje na ogół wysoką korelację $(\mathrm{r}=0,65-0,85)$ i zgodność zmian w fazie w obu przebiegach. Występują jednak momenty lub na ogół krótkie, 2-5-letnie okresy, w których zaznaczają się poważniejsze różnice w amplitudzie zmian temperatury z roku na rok (ryc. 4). Należy jednak mieć na uwadze, że $\mathrm{PL}_{\mathrm{ZR}}$ jest średnią temperaturą obliczaną z okresu od grudnia do marca włącznie, gdy rekonstrukcja Luterbachera i in. (2006) stanowi średnią temperaturę 


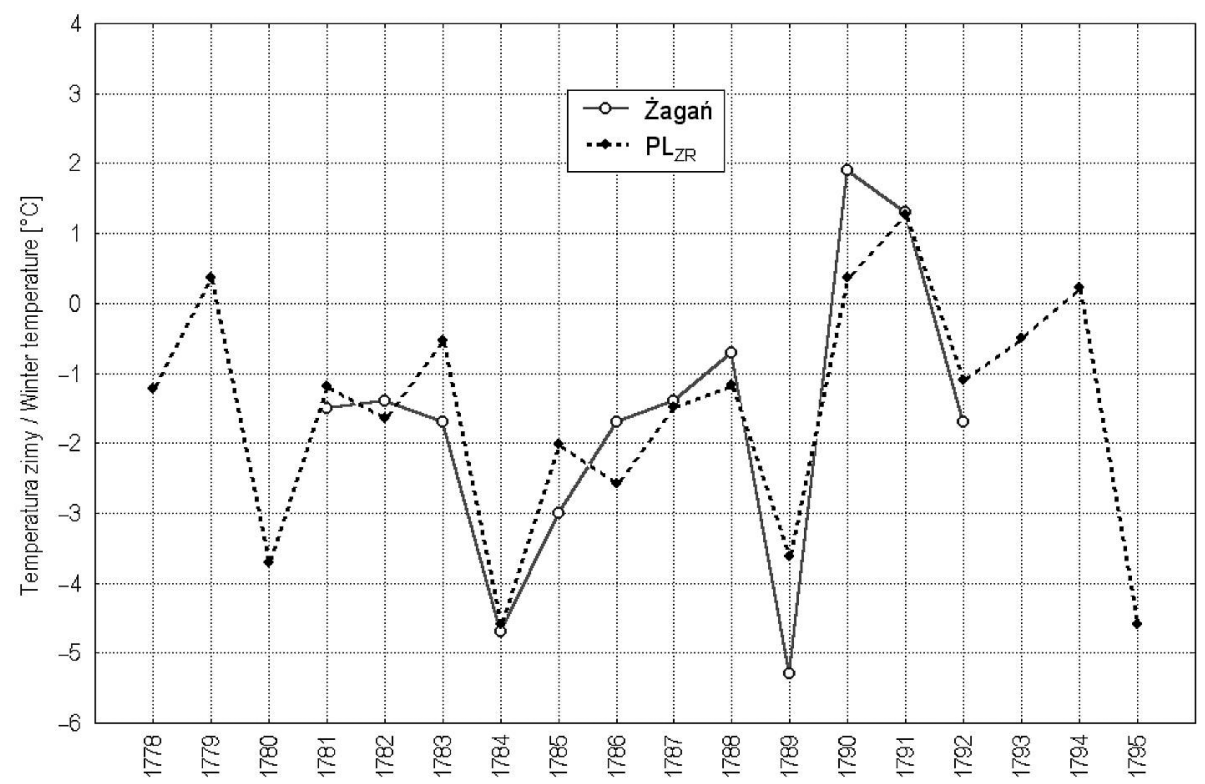

Ryc. 3. Przebieg obserwowanej temperatury zimy (12-02) w Żaganiu w latach 1781-1792 według Przybylaka, Pospieszyńskiej i in. (2014b) ze zrekonstruowanymi za pomocą równania obszarowej temperatury zimy $\left(\mathrm{PL}_{\mathrm{ZR}} ; 12-03\right)$

Fig. 3. Course of the observed winter temperature (DJF) in Żagań in the years 1781-1792 according to Przybylak, Pospieszyńska, et al. (2014b) with the area winter temperature reconstructed by the equation $\left(\mathrm{PL}_{Z \mathrm{R}} ; \mathrm{DJFM}\right)$

zimy nad Europą z okresu od grudnia do lutego. Nadto trudno przyjąć, aby kierunek zmienności temperatury konkretnej zimy nad obszarem Europy miał na całym tym obszarze jednakowy znak. Kierunek zmian temperatury w czasie danej zimy nad obszarem Polski, która stanowi 10-15\% powierzchni, dla której Luterbacher i in. (2006) szacują wartości średnie temperatury zimy, nie musi być taki sam jak na przykład nad Niziną Rosyjską, Półwyspem Bałkańskim czy obszarem Francji.

$\mathrm{Z}$ wartości rekonstruowanych $\left(\mathrm{PL}_{\mathrm{ZR}}\right)$ i wartości obserwowanych (średnia temperatura „obszarowa” zimy - $\mathrm{PL}_{\mathrm{zO}}$ ) utworzono następnie jeden kombinowany szereg czasowy od roku 1720 do 2015 (296 lat), w którym we wszystkich latach, dla których były wartości pochodzące z obserwacji instrumentalnych wartości $\mathrm{PL}_{\mathrm{ZR}}$ zastąpiono wartościami $\mathrm{PL}_{\mathrm{zO}}$. Przyjęto tu bezwzględny priorytet wartości obserwowanych nad rekonstruowanymi. W sumie w połączonym szeregu jest 140 wartości obserwowanych 


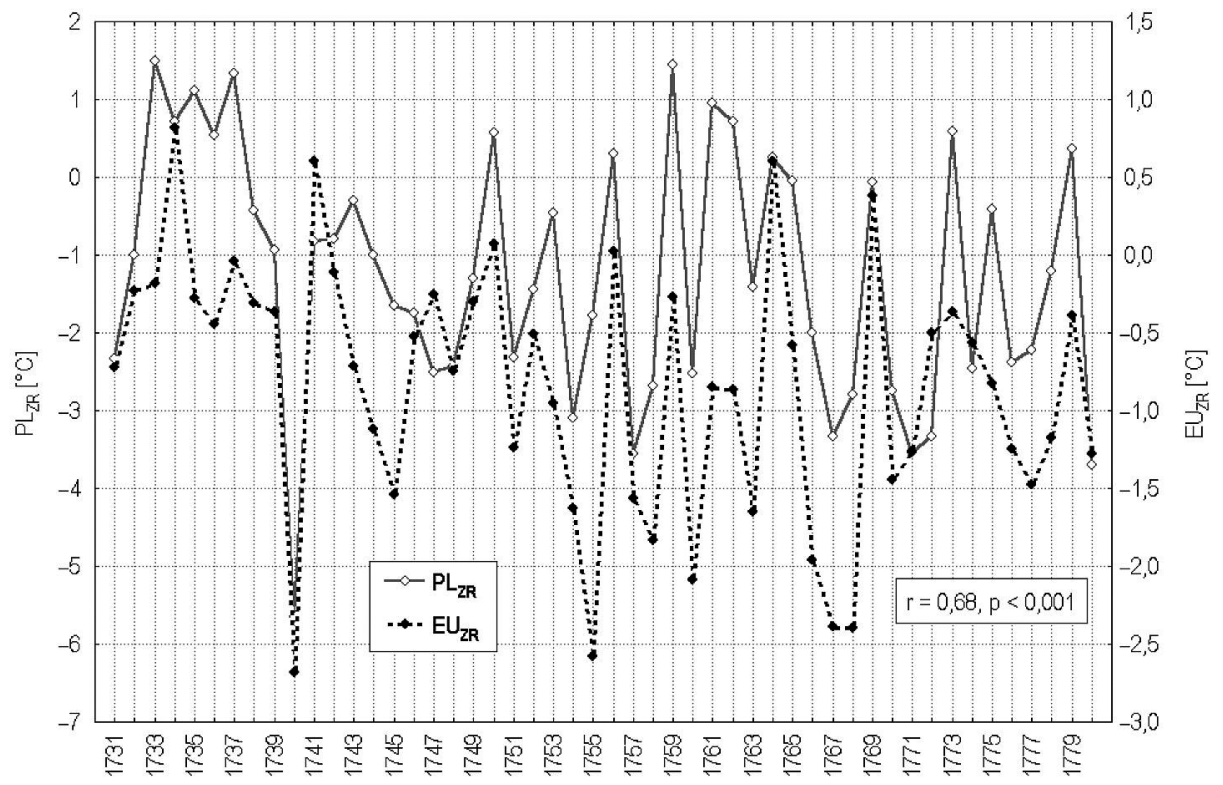

Ryc. 4. Porównanie przebiegów zrekonstruowanej średniej obszarowej temperatury zimy nad Polską $\left(\mathrm{PL}_{Z \mathrm{R}} ; 12-03\right)$ i zrekostruowanej przez Luterbachera i in. (2006) średniej temperatury zimy w Europie $\left(\mathrm{EU}_{\mathrm{ZR}} ; 12-02\right)$ w latach $1731-1780$

Fig. 4. Comparison of the courses of the reconstructed mean area winter temperature over Poland $\left(\mathrm{PL}_{\mathrm{ZR}} ; \mathrm{DJFM}\right)$ and average winter temperature in Europe $\left(\mathrm{EU}_{\mathrm{ZR}} ; \mathrm{DJF}\right)$ in 1731-1780 reconstructed by Luterbacher et al. (2006)

$\left(\mathrm{PL}_{\mathrm{ZO}}\right)$ i 156 wartości rekonstruowanych $\left(\mathrm{PL}_{\mathrm{ZR}}\right)$. Wartości rekonstruowane tworzą początkową część szeregu (1720-1836, 1842-1850, 1858-1882), w drugiej jego części wypełniają jedynie pojedyncze braki wartości obserwowanych (lata: 1895, 1897, 1916-1917 i 1940). Dalej, jako symboliczne oznaczenie wartości tego kombinowanego szeregu będzie przyjmowało się akronim $\mathrm{PL}_{\mathrm{Z}}$ (Polska, zima). Szereg chronologiczny wartości $\mathrm{PL}_{\mathrm{Z}}$ w latach 1720-2015, z oznaczonymi wartościami rekonstruowanymi $\left(\mathrm{PL}_{\mathrm{ZR}}\right)$ i obserwowanymi $\left(\mathrm{PL}_{\mathrm{ZO}}\right)$ zawiera załącznik 1. 


\section{Statystyczne cechy przebiegu średniej obszarowej temperatury zim w wieloleciu 1720-2015}

Przebieg wartości średniej obszarowej temperatury zim zestawionych za pomocą omówionej metodyki przedstawia ryc. 5. Wykazuje on silną korelację dodatnią $(0,80, \mathrm{p}<<0,001) \mathrm{z}$ szeregiem wartości średniej temperatury zimy w Europie (lata 1720-2004), zrekonstruowanym przez Luterbachera i in. (2006). Mimo tego, że Luterbacher i in. (2006) traktują okres zimowy odmiennie, niż przyjmuje się w tej pracy, współczynnik korelacji jest bardzo wysoki.

Prowadząc analizę szeregu temperatury obszarowej zimy nad Polską $\left(\mathrm{PL}_{Z}\right)$, trzeba pamiętać, że średni błąd standardowy estymacji wartości zrekonstruowanych $\mathrm{PL}_{\mathrm{ZR}}$ jest, w stosunku do ich bezwzględnych wartości, stosunkowo duży. Zastosowana metoda rekonstrukcji „ścina” w niektórych przypadkach wartości ekstremalne, zarówno ujemne, jak i dodatnie. Taka sytuacja powoduje, że zdaniem autorów nie należy przywiązywać nadmiernej wagi do niewielkich różnic jednostkowych między rekonstruowanymi wartościami temperatury w poszczególnych latach w pierwszej

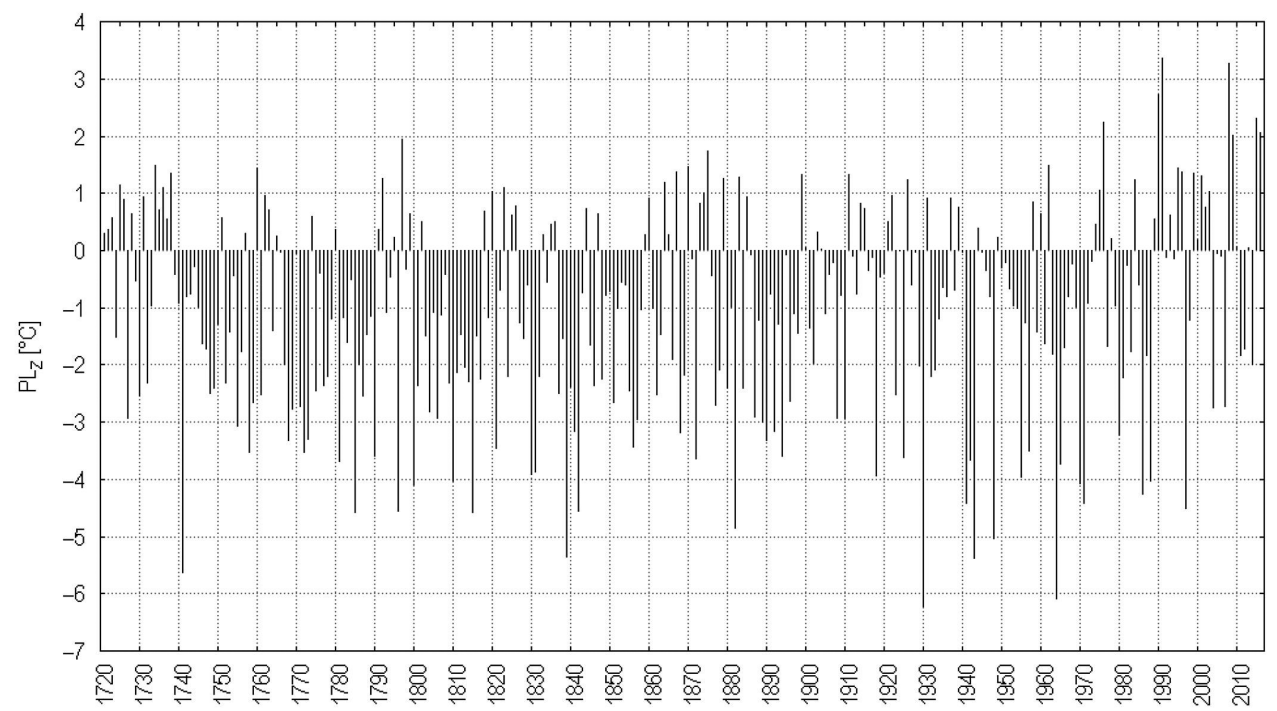

Ryc. 5. Przebieg zrekonstruowanej średniej obszarowej temperatury zimy (PL $\left.\mathrm{P}_{Z} ; 12-03\right)$ w latach 1720-2015. Błąd standardowy szacunku wartości zrekonstruowanych $\pm 1,06^{\circ} \mathrm{C}$

Fig. 5. Course of the reconstructed mean area winter temperature $\left(\mathrm{PL}_{Z} ;\right.$ Dec-Mar) in the years 1720-2015. Standard error of the estimate of the reconstructed values $\pm 1.06^{\circ} \mathrm{C}$ 
połowie szeregu, natomiast stosunkowo pewne wnioski można wyciągać na temat składowych długookresowych zmian temperatury w całym szeregu czasowym.

W całym rozpatrywanym wieloleciu 1720-2015 (296 lat) średnia wartość $\mathrm{PL}_{Z}$ jest równa $-1,09^{\circ} \mathrm{C}$, a odchylenie standardowe $(\sigma)$ równe $1,80^{\circ} \mathrm{C}$. Wskazuje to na występowanie w przebiegu temperatury zim znacznej zmienności. Mimo to tylko nieliczne wartości $\mathrm{PL}_{z}$ wykraczają poza granice $\pm 2 \sigma$, jakimi są $-4,69 \mathrm{i}+2,51^{\circ} \mathrm{C}$. Poza granicę średnia $\pm 3 \sigma\left(-6,49 \mathrm{i}+4,31^{\circ} \mathrm{C}\right)$ nie wykracza żadna wartość $\mathrm{PL}_{Z}$.

Przebieg $\mathrm{PL}_{z}$ jest niestacjonarny. Na tle wahań o dłuższych, kilku-, dwudziestokilkuletnich okresach, w całym szeregu występuje bardzo słaby, nieistotny statystycznie trend dodatni $\left(+0,0020( \pm 0,0012)^{\circ} \mathrm{C} \cdot \mathrm{rok}^{-1} ; \mathrm{p}=0,103\right)$. Objaśnia on zaledwie $0,5 \%$ wariancji temperatury zim w rozpatrywanym niemal 300-letnim okresie i nie odgrywa żadnej roli w objaśnieniu zmienności ich temperatury. Wobec znacznej zmienności $\mathrm{PL}_{\mathrm{Z}}$ o skali dekadowej i multidekadowej występują w poszczególnych fragmentach szeregu dodatnie i ujemne subtrendy, niekiedy nawet statystycznie istotne, które charakteryzują następujące po sobie lokalne fazy ochłodzeń i ociepleń zim.

Zakres zmienności wartości $\mathrm{PL}_{\mathrm{Z}}$ mieści się w granicach od -6,24 (rok 1929) do $+3,35^{\circ} \mathrm{C}$ (rok 1990). Obie te wartości są wartościami obserwowanymi. Zważywszy na wielkość błędu standardowego estymacji wartości zrekonstruowanych, nie można wykluczyć, że rzeczywista najniższa temperatura zimy mogła wystąpić w roku 1740 (oszacowana $\left.\mathrm{PL}_{\mathrm{Z}}=-5,65^{\circ} \mathrm{C}\right)^{6}$. $\mathrm{Gdyby}$ istotnie tak było, oznaczałoby to, że najchłodniejsza zima w latach $1720-2015$, obserwowana w XVIII w. $\left(-6,71^{\circ} \mathrm{C}\right.$ ) była chłodniejsza tylko o około $0,5^{\circ} \mathrm{C}$ od najchłodniejszej zimy w XX w. ${ }^{7}$, której rzeczywista temperatura nie budzi wątpliwości.

Zdecydowanie przeważają zimy „chłodne” o ujemnej temperaturze średniej obszarowej (72\% wszystkich przypadków). Rozkład przypadków nieznacznie odbiega od normalnego (ryc. 6), wykazując lekką lewoskośność $(-0,33( \pm 0,14)$ ). Dalej, dla uproszczenia, w dalszych ocenach przyjmie się za granice zim ekstremalnie chłodnych i ekstremalnie ciepłych wartości $\mathrm{PL}_{z}$ równe $-5,0$ i $+2,0^{\circ} \mathrm{C}$. Nie są to wartości wynikające z granic określanych przez $\pm 2 \sigma$, ale wartości dwu skrajnych, jednostopniowych przedziałów w histogramie rozkładu.

\footnotetext{
${ }^{6} \mathrm{Z}$ zapisów pogodowych prowadzonych w Gdańsku w latach 1722-1769 (patrz: Przybylak, Filipiak i Oliński 2014a) wynika, że zima roku 1740 była bardzo chłodna, podobnie Dobrovolny i in. (2010) wskazują na wyjątkowo surową zimę w tym roku na obszarze Czech. W rekonstrukcji średniej temperatury zim (DJF) w Europie, dokonanej przez Luterbachera i in. (2006), zima roku 1740 jest również znacznie chłodniejsza od przeciętnych, ale najchłodniejszą europejską zimą w latach 1720-2004 w rekonstrukcji Luterbachera i in. (2006) jest zima roku 1942. W Polsce najniższa średnia obszarowa temperatura zimy została odnotowana w roku 1929. Moment wystąpienia najniższej dla całej Europy średniej temperatury zimy i moment wystąpienia najniższej temperatury zimy nad Polską nie musi być tożsamy.

${ }^{7}$ Możliwe odchylenie in minus od oszacowanej wartości $\mathrm{PL}_{\mathrm{ZR}} \mathrm{w}$ roku 1740, uwzględniające wartość i ujemny znak BSE (Błędu Standardowego Estymacji) to $-6,71^{\circ} \mathrm{C}$.
} 


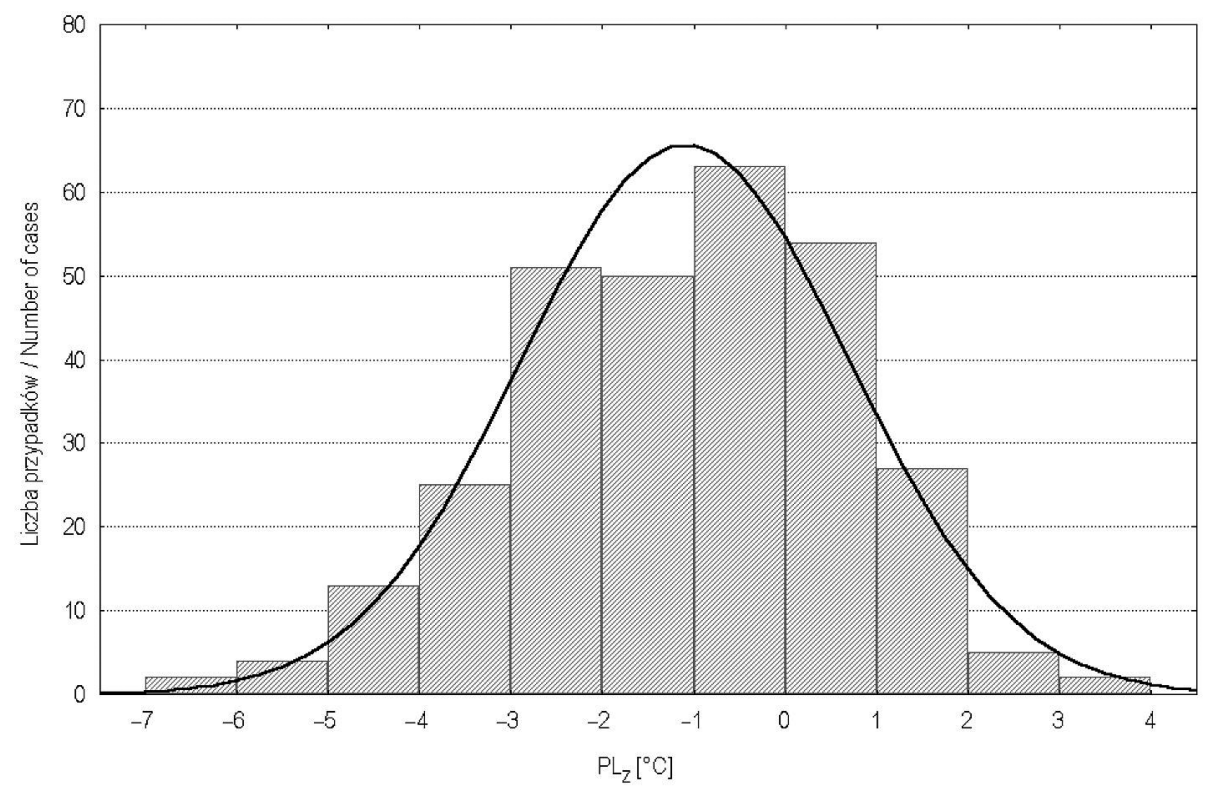

Ryc. 6. Rozkład liczebności przypadków wartości średniej obszarowej temperatury zim $\left(\mathrm{PL}_{z} ; 12-03\right)$ nad Polską (1720-2015; przedziały jednostopniowe)

Fig. 6. Distribution of the number of cases of the mean area winter temperature $\left(\mathrm{PL}_{Z}\right.$; Dec-Mar) over Poland (1720-2015, single-stage intervals)

Najczęściej występującymi w rozpatrywanym 296-leciu są średnie $\mathrm{PL}_{z}$ mieszczące się w przedziale między -1 a $0^{\circ} \mathrm{C}$ (63 na 296 przypadków). Odpowiada to sytuacjom, w których w czasie zimy występują najczęściej dwa miesiące o niezbyt niskiej temperaturze ujemnej (zazwyczaj styczeń i luty o średniej temperaturze w granicach $-0,1$ do $-5^{\circ} \mathrm{C}$ ), a dwa miesiące zimowe mają niezbyt wysoką temperaturę dodatnią (przykład - rok 1894 z temperaturą od grudnia do marca kolejno $+0,2$, $-4,4,-0,2 \mathrm{i}+4,0^{\circ} \mathrm{C} ; \mathrm{PL}_{\mathrm{Z}}=-0,1^{\circ} \mathrm{C}$ ) lub trzy miesiące $\mathrm{z}$ niewielką ujemną temperaturą i jeden miesiąc z temperaturą dodatnią (przykład - rok 1908: -2,5, $-2,2,-0,2 \mathrm{i}+1,6^{\circ} \mathrm{C}$; $\left.\mathrm{PL}_{\mathrm{Z}}=-0,8^{\circ} \mathrm{C}\right)$, przy czym $\mathrm{w}$ takich przypadkach częściej dodatnia temperatura występuje w marcu niż grudniu.

Drugie pod względem liczności są zimy z temperaturą w przedziale między $0 \mathrm{a}+1^{\circ} \mathrm{C}$ (54 przypadki). Odpowiada to sytuacji, w której w czasie zimy występuje zazwyczaj jeden miesiąc z temperaturą niższą od zera (przykład - przebieg temperatury w miesiącach zimowych roku 1936, w którym średnia miesięczna obszarowa temperatura od grudnia do marca była kolejno równa $+0,4,+1,9,-3,2 \mathrm{i}+4,6^{\circ} \mathrm{C}\left(\mathrm{PL}_{\mathrm{Z}}=+0,92\right)$ 
lub dwa miesiące z temperaturą niższą od zera i na ogół dość ciepłym grudniem i/lub marcem (przykład - rok 1913: +2,2, -3,1, -0,7 i +5,0 C; $\left.\mathrm{PL}_{\mathrm{Z}}=+0,85\right)$. Zimy mieszczące się w tych dwu przedziałach średniej temperatury stanowią 39,5\% wszystkich zim występujących w rozpatrywanym prawie 300-letnim okresie. Takie raczej łagodne, niezbyt długie i niezbyt mroźne zimy, należy w całym badanym okresie uznać za typowe i przeciętne.

Zimy ekstremalnie chłodne, o średniej temperaturze niższej od $-5^{\circ} \mathrm{C}$ w rozpatrywanym okresie wystąpiły sześciokrotnie (lata: 1740, 1838, 1929, 1942, 1947 i 1963), co stanowi zaledwie $2 \%$ wszystkich przypadków. Są to zimy, w których wszystkie jej miesiące mają temperaturę ujemną, a przynajmniej w jednym miesiącu temperatura miesięczna jest niższa od $-10^{\circ} \mathrm{C}$, a w drugim niższa od $-5^{\circ} \mathrm{C}$ (np. rok 1963 $\mathrm{z}$ miesięcznymi wartościami temperatury od grudnia do marca kolejno: $-4,3,-10,8$, $-7,6 \mathrm{i}-1,7^{\circ} \mathrm{C}\left(\mathrm{PL}_{\mathrm{Z}}=-6,1^{\circ} \mathrm{C}\right)$ lub rok $1942 \mathrm{z}$ temperaturą: $-0,5,-11,0,-6,7 \mathrm{i}-3,5^{\circ} \mathrm{C}$ $\left(\mathrm{PL}_{\mathrm{Z}}=-5,4^{\circ} \mathrm{C}\right)$. Większość zim ekstremalnie chłodnych wystąpiła nie w XVIII czy XIX, ale w XX w.

Zimy ekstremalnie ciepłe, o średniej temperaturze równej, wyższej od $+2^{\circ} \mathrm{C}$ w rozpatrywanym okresie wystąpiły siedmiokrotnie (2,3\%), wszystkie w końcowej części rozpatrywanego okresu (lata: 1975, 1989, 1990, 2007, 2008, 2014 i 2015). Są to zimy, w których wszystkie miesiące mają temperaturę dodatnią (np. zima roku 2008 z temperaturą: $+0,2,+0,9,+3,0 \mathrm{i}+3,9\left(\mathrm{PL}_{\mathrm{Z}}=2,0^{\circ} \mathrm{C}\right)$ albo tylko jeden, najchłodniejszy z miesięcy zimowych, ma ujemną temperaturę powietrza, z reguły wyższą od $-1^{\circ} \mathrm{C}$ (np. zima 1975 roku z wartościami temperatury miesięcznej: +2,9, +2,6, -0,6 $\mathrm{i}+4,1^{\circ} \mathrm{C}\left(\mathrm{PL}_{\mathrm{Z}}=2,2^{\circ} \mathrm{C}\right)$. Najcieplejsza zima w całym rozpatrywanym okresie wystąpiła w roku 1990 , miała średnią temperaturę obszarową równą $+3,4^{\circ} \mathrm{C}$, a kolejne wartości temperatury miesięcznej to: $+0,8,+1,6,+4,6 \mathrm{i}+6,5^{\circ} \mathrm{C}$.

Analiza zmian długookresowych w przebiegu średniej temperatury zim napotyka poważne problemy metodyczne. Wyznaczenie dłuższych, względnie jednorodnych okresów, za pomocą takiej czy innej filtracji wartości w szeregu czasowym (najczęściej stosuje się wyrównywanie przebiegów za pomocą średnich konsekutywnych lub filtrów Gaussa) jest wysoce subiektywne. W zależności od przyjęcia długości „okna czasowego" filtracji można a priori uzyskać bez trudu pożądany ${ }^{8}$ wynik, będący artefaktem statystycznym, niekoniecznie mającym wiele wspólnego ze zbliżonym do rzeczywistego obrazem występującej zmienności. Takie wyrównywanie zmienia zarówno amplitudę zmian długookresowych, jak i wartości trendów, przesuwa w czasie momenty występowania lokalnych minimów i maksimów, a tym samym granice

\footnotetext{
${ }^{8}$ Filtracja nie jest metodą badawczą. Stanowi metodę takiego przekształcenia sygnału, aby uzyskać pożądany jego przebieg (uwypuklić lub wyeliminować składowe nisko-, lub wysokoczęstotliwościowe w przebiegu, ograniczyć amplitudę, wyeliminować impulsy o dużej amplitudzie, traktowane jako zakłócenia, zamienić przebiegi okresowe na prostokątne, piłokształtne etc. (patrz niemal dowolny podręcznik elektroniki lub podręcznik z zakresu analizy sygnału).
} 
okresów „chłodnych” i „,ciepłych” oraz zmienia ich „okresowość”. Jeśli na przykład chce się wykazać „niebywały” czy „dramatyczny” wzrost średniej temperatury zim w ostatnich latach rozpatrywanego okresu, wystarczy zastosować kilkunastoletnie okno czasowe (ryc. 7). Przy przyjęciu innego, krótszego okna czasowego filtracji uzyskany obraz zmian jest diametralnie różny i bliższy rzeczywistości (ryc. 8), choć trudniej czytelny i w niewielkim stopniu potwierdzający „niebywały” wzrost temperatury zim w ostatnim trzydziestoleciu.

Podobnie, uśrednianie temperatury w pentadach lub dekadach, z czym często spotyka się w analizach zmian długookresowych (np. Przybylak i in. 2004; Przybylak 2006),

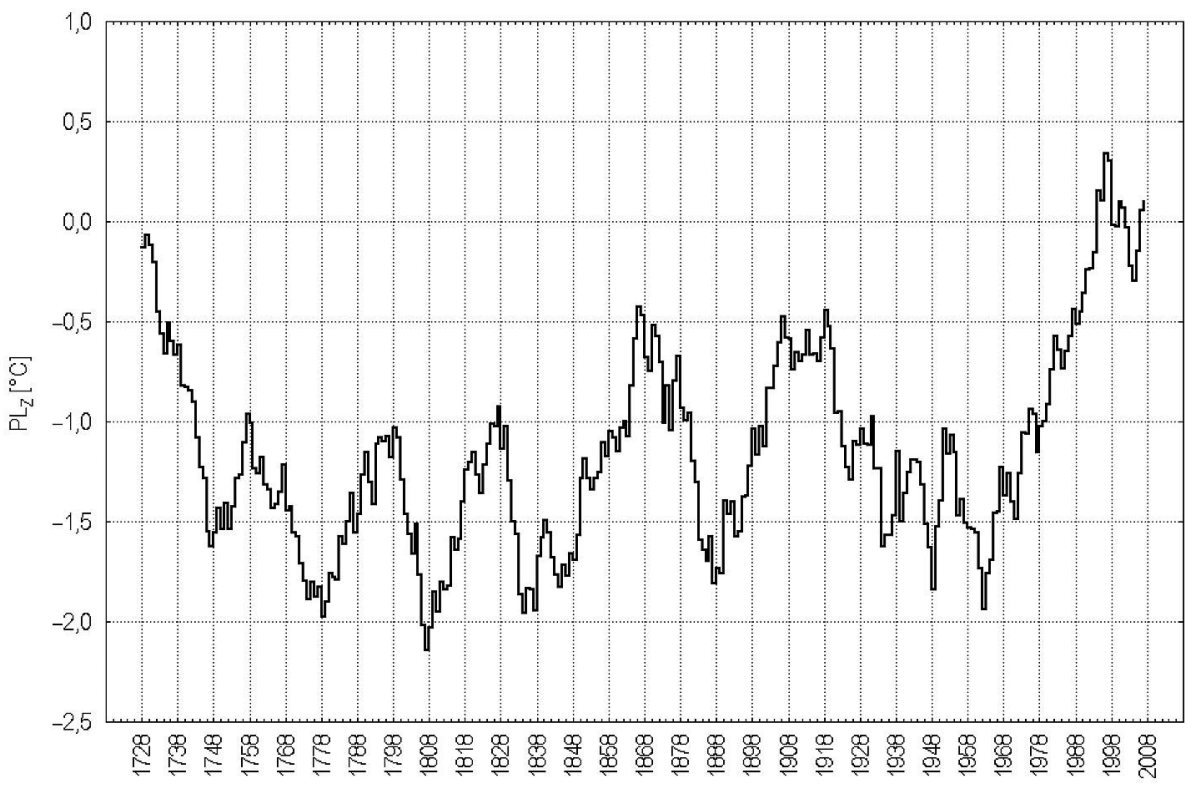

Ryc. 7. Przebieg średniej obszarowej temperatury zim nad Polską $\left(\mathrm{PL}_{\mathrm{Z}}\right)$, wyrównany 17-punktową średnią kroczącą. Rycina demonstruje występowanie długookresowych wahań temperatury o okresie od kilkunastu do ponad czterdziestu lat i amplitudzie od 1 do $1,5^{\circ} \mathrm{C}$. Zauważa się niezmiernie szybki i gwałtowny, niemal liniowy wzrost temperatury zim o niemal 2,3ㄷ między 1962 a $1998 \mathrm{r}$.

Fig. 7. Course of the mean area winter temperature over Poland $\left(\mathrm{PL}_{\mathrm{Z}}\right)$, aligned with the 17-point moving average. The figure demonstrates the occurrence of long-term temperature fluctuations from a dozen to over forty years and amplitude from 1 to $1.5^{\circ} \mathrm{C}$. An extremely fast and rapid, almost linear increase in winter temperatures by almost $2.3^{\circ} \mathrm{C}$ is observed between 1962 and 1998 


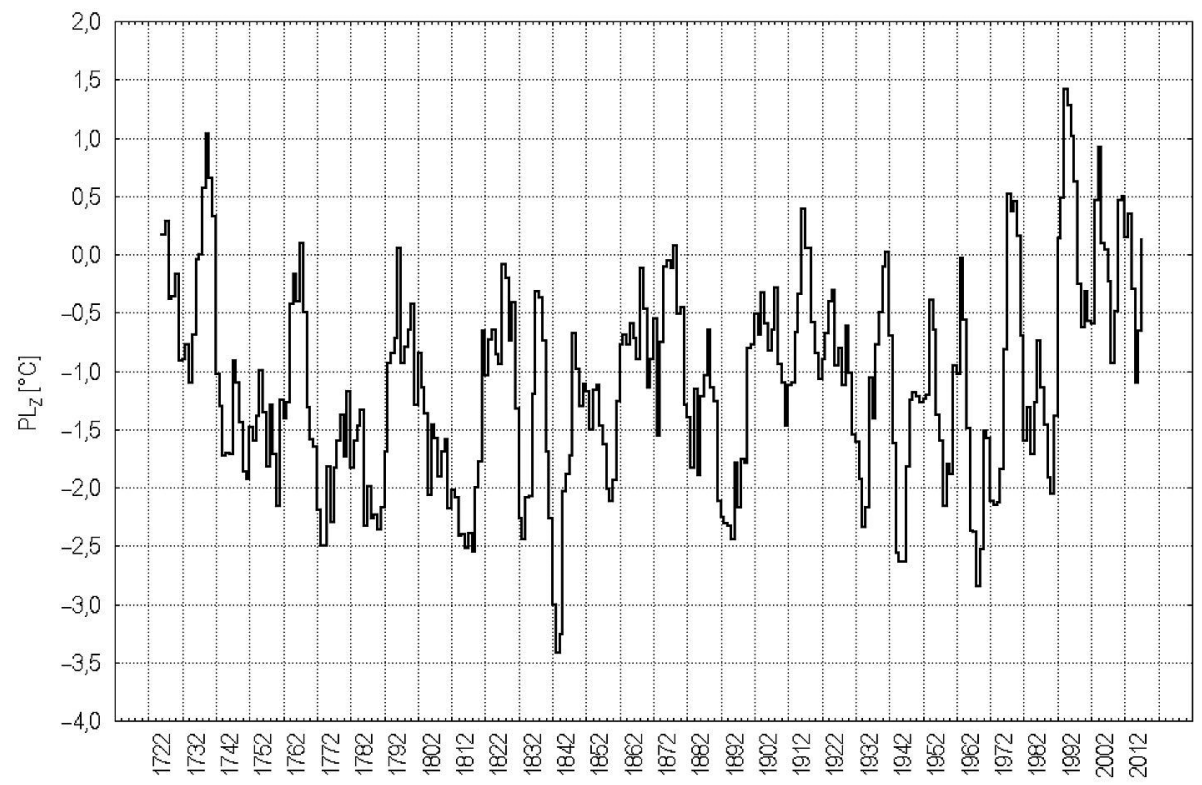

Ryc. 8. Przebieg średniej obszarowej temperatury zim nad Polską $\left(\mathrm{PL}_{\mathrm{Z}}\right)$, wyrównany 5-punktową średnią kroczącą. Zauważa się różnice w charakterze przebiegu (momenty wystąpienia lokalnych minimów i maksimów przebiegu, amplituda wahań) w stosunku do poprzedniej ryciny. Zwraca uwagę zasadnicza różnica w momentach wystąpienia minimum temperatury zim na obu rycinach oraz zaznaczający się po roku 1995 spadek średniej obszarowej temperatury zim

Fig. 8. Course of mean area winter temperature over Poland $\left(\mathrm{PL}_{\mathrm{Z}}\right)$, aligned with a 5-point moving average. There are differences in the nature of the course (moments of occurrence of local minima and maxima of the course, amplitude of fluctuations,) in relation to the previous figure. The significant difference between the moments of the minimum winter temperature on both figures and the decrease in the average area winter temperatures after 1995 are noteworthy

nie prowadzi do uzyskania klarownego obrazu takich zmian'. Bardzo silnie tłumiona jest amplituda zmian temperatury. Jeśli zmiana reżimu termicznego jest szybka i następuje w jednej pentadzie czy dekadzie, momenty zmian reżimu termicznego

\footnotetext{
${ }^{9} \mathrm{Z}$ punktu widzenia teorii filtracji jest to klasyczne przekształcenie nieregularnego przebiegu okresowego w przebieg prostokątny o odmiennym okresie i amplitudzie proporcjonalnej do średniej mocy sygnału w ,oknie” próbkowania.
} 
nie są wykrywane lub zostają przesunięte w czasie. Dotyczy to szczególnie wahań temperatury o dużej amplitudzie i skali kilkuletniej, w których moment lokalnego maksimum lub minimum przebiegu temperatury występuje na granicy długości okna czasowego uśredniania lub blisko $( \pm 2, \pm 3$ lata) tej granicy. Przesunięcie początku okna czasowego zliczania dekad o jeden rok czy dwa lata (np. z roku 1721 na 1720 lub 1722) potrafi całkowicie zmienić uzyskany obraz rozkładu zmian w czasie, poprzez duże zmiany średnich we wszystkich kolejnych dekadach.

Przeglądając przebieg zmian średniej temperatury zimy na ryc. 5, nietrudno zauważyć, że na tle dominacji zim „chłodnych”, o średniej temperaturze niższej od zera, występują w nieregularnych odstępach czasu zimy „ciepłe”, o średniej temperaturze wyższej od $0^{\circ} \mathrm{C}$, tworzące samodzielne, na ogół mało liczne skupienia czy mniej lub bardziej liczne skupienia, będące kombinacjami zim ciepłych i chłodnych o różnych proporcjach jednych do drugich. Występowanie skupień w czasie zim „ciepłych” i zim „chłodnych” wraz z charakterystycznie kształtującymi się kombinacjami średnich wartości oraz minimów i maksimów temperatury w danym skupieniu, które tworzą strukturę takiego „podokresu”, może stanowić podstawę dla podziału szeregu czasowego $\mathrm{PL}_{Z}$ na poszczególne podokresy o względnie indywidualnych cechach.

Przeprowadzona pod tym kątem analiza ujawnia w rozpatrywanym okresie lat 1720-2015 istnienie 23 podokresów o różnym czasie trwania - od 4 do 28 lat. Ich zestawienie wraz z podstawową charakterystyką statystyczną zawiera tab. 4.

Analizując zawartość tab. 4, zauważa się dużą zmienność czasu trwania poszczególnych podokresów oraz stopnia ich stabilności. Pod mianem stabilności podokresu rozumie się dalej względnie podobny charakter termiczny występujących w nim zim. Za stabilne uważa się dalej podokresy, w których występują wartości $\mathrm{PL}_{Z}$ o jednakowym znaku lub zdecydowanie dominują ( $>75 \%$ frekwencji) $\mathrm{PL}_{Z}$ o takim samym znaku.

Najczęściej występującymi stabilnymi podokresami są podokresy różnej długości z występowaniem zim „chłodnych”, które mają temperaturę niższą od $0^{\circ} \mathrm{C}$ (podokresy o numerach: 6, 8, 10, 13, 15 i 19) i podokresy stabilne, z niewielkim tylko udziałem zim o temperaturze wyższej od $0^{\circ} \mathrm{C}$ (podokresy: 2, 4, 11, 16, 17 i 21). Spośród stabilnych podokresów zim o dodatniej temperaturze w całym rozpatrywanym okresie można warunkowo dopatrzyć się wystąpienia tylko jednego - jest to podokres 22 (1988-2002) - w którym frekwencja zim „,ciepłych” jest jednak nieco mniejsza $(73,3 \%)$ od przyjętej granicy $75 \%$. W całym szeregu nieco większy udział mają podokresy stabilne w pierwszej jego połowie (1720-1868), gdzie łączny czas ich trwania wynosi 90 lat, gdy w drugiej jego części (1869-2015) 73 lata.

Najdłuższy z podokresów, trwający 28 lat (podokres 12: 1858-1885), jest wyjątkowo niestabilny - występowanie w nim zim „chłodnych” o zróżnicowanych średnich wartościach $\mathrm{PL}_{Z}$ przerywają bardzo często zimy „ciepłe” o średniej temperaturze wyższej od zera, które stanowią $43 \%$ czasu tego podokresu. Dwa następne podokresy 
Tab. 4. Długookresowa zmienność charakteru zim; czas trwania podokresów o względnie podobnym przebiegu temperatury $\left[{ }^{\circ} \mathrm{C}\right]$ i ich charakterystyka statystyczna

Table 4. Long-term variability of winter character; duration of sub-periods with a relatively similar temperature $\left[{ }^{\circ} \mathrm{C}\right]$ course and their statistical characteristics

\begin{tabular}{|c|c|c|c|c|c|c|c|}
\hline \multirow{2}{*}{$\mathrm{Nr}$} & \multirow{2}{*}{ Lata } & \multirow{2}{*}{$\begin{array}{l}\text { Średnia tempe- } \\
\text { ratura zim } \\
\text { w podokresie } \\
\text { i odchylenie } \\
\text { standardowe } \\
\text { (w nawiasach) }\end{array}$} & \multirow{2}{*}{$\begin{array}{l}\text { Długość } \\
\text { podokresu } \\
\text { (lata) }\end{array}$} & \multicolumn{2}{|c|}{$\begin{array}{l}\text { Liczba zim } \\
\text { w podokresie } \\
\text { z temperaturą }\end{array}$} & \multicolumn{2}{|c|}{$\begin{array}{c}\text { Zakres zmian temperatury zim } \\
\text { w podokresie (w nawiasach - rok } \\
\text { wystąpienia) }\end{array}$} \\
\hline & & & & ujemną & dodatnią & $\operatorname{Min}\left({ }^{\circ} \mathrm{C}\right)$ & $\operatorname{Max}\left({ }^{\circ} \mathrm{C}\right)$ \\
\hline 1 & $1720-1737$ & $-0,05(1,42)$ & 18 & 6 & 12 & $-2,95(1726)$ & $+1,50$ (1733) \\
\hline 2 & $1738-1760$ & $-1,53(1,62)$ & 23 & 20 & 3 & $-5,56(1740)$ & $+1,45(1759)$ \\
\hline 3 & $1761-1765$ & $+0,09(0,93)$ & 5 & 2 & 3 & $-1,41(1763)$ & $+0,96(1761)$ \\
\hline 4 & $1766-1789$ & $-2,00(1,37)$ & 24 & 22 & 2 & $-4,59(1784)$ & $+0,59(1773)$ \\
\hline 5 & 1790-1801 & $-0,67(2,04)$ & 12 & 6 & 6 & $-4,58(1795)$ & $+1,26(1791)$ \\
\hline 6 & $1802-1816$ & $-2,18(1,11)$ & 15 & 15 & 0 & $-4,61(1814)$ & $-0,43(1807)$ \\
\hline 7 & $1817-1825$ & $-0,38(1,63)$ & 9 & 4 & 5 & $-3,47(1820)$ & $+1,10(1822)$ \\
\hline 8 & $1826-1831$ & $-2,25(1,39)$ & 6 & 6 & 0 & $-3,94(1829)$ & $-0,63(1828)$ \\
\hline 9 & $1832-1835$ & $+0,16(0,50)$ & 4 & 1 & 3 & $-0,58(1833)$ & $+0,50(1835)$ \\
\hline 10 & $1836-1842$ & $-2,73(1,35)$ & 7 & 7 & 0 & $-5,12(1838)$ & $-0,75(1842)$ \\
\hline 11 & 1843-1857 & $-1,42(1,26)$ & 15 & 13 & 2 & $-3,44(1855)$ & $+0,74(1843)$ \\
\hline 12 & 1858-1885 & $-0,71(1,84)$ & 28 & 16 & 12 & $-4,87(1881)$ & $+1,73(1874)$ \\
\hline 13 & 1886-1897 & $-2,06(1,79)$ & 12 & 12 & 0 & $-3,61(1893)$ & $-0,10(1894)$ \\
\hline 14 & 1898-1914 & $-0,48(1,30)$ & 17 & 10 & 7 & $-2,95(1907)$ & $+1,34(1898)$ \\
\hline 15 & $1915-1920$ & $-1,07(1,62)$ & 5 & 5 & 0 & $-3,96(1917)$ & $-0,13(1916)$ \\
\hline 16 & 1921-1938 & $-1,00(1,91)$ & 18 & 14 & 4 & $-6,24(1929)$ & $+1,23(1925)$ \\
\hline 17 & $1939-1956$ & $-1,74(1,99)$ & 18 & 16 & 2 & $-5,40(1942)$ & $+0,39(1943)$ \\
\hline 18 & $1957-1961$ & $-0,03(1,42)$ & 5 & 2 & 3 & $-1,64(1960)$ & $+1,48(1961)$ \\
\hline 19 & $1962-1971$ & $-2,49(1,95)$ & 10 & 10 & 0 & $-6,11(1963)$ & $-0,26(1967)$ \\
\hline 20 & 1972-1977 & $+0,34(1,31)$ & 6 & 2 & 4 & $-1,69(1976)$ & $+2,23(1975)$ \\
\hline 21 & 1978-1987 & $-1,81(1,73)$ & 10 & 9 & 1 & $-4,28(1985)$ & $+1,22(1983)$ \\
\hline 22 & 1988-2002 & $+0,57(1,80)$ & 15 & 4 & 11 & $-4,52(1996)$ & $+3,35(1990)$ \\
\hline 23 & 2003-2015 & $-0,12(2,04)$ & 13 & 7 & 6 & $-2,77(2003)$ & $+3,27(2007)$ \\
\hline
\end{tabular}

pod względem czasu ich trwania, dłuższe od 20 lat (23 i 24 lata; podokresy 2 i 4), które występują w początkowej części szeregu (ryc. 3 i tab. 4) są „chłodne” i stabilne zdecydowanie dominują zimy „chłodne”, występowanie zim „ciepłych” w czasie ich trwania jest sporadyczne (13 i $8 \%$ czasu ich trwania).

Najkrótsze podokresy trwające od 4 do 7 lat są względnie jednolite, choć nie wszystkie są stabilne. Dość wyraźnie dzielą się na dwa typy - podokresy o średniej temperaturze niższej od $0^{\circ} \mathrm{C}$, tworzone wyłącznie przez zimy „, chłodne” $(8,10,15)$, stanowiące często krótkie serie „ostrych” zim (stabilne) oraz podokresy o znacznych 
międzyrocznych wahaniach temperatury, w których zimy „ciepłe” przeplatają się z zimami „chłodnymi” (niestabilne). Te ostatnie typy najkrótszych podokresów mają zazwyczaj dodatnią temperaturę średnią (podokresy: 3, 9, 20) lub średnią temperaturę nieznacznie tylko niższą od $0^{\circ} \mathrm{C}$ (podokres 18 : $-0,03^{\circ} \mathrm{C}$ ), stanowiąc relatywnie krótkie serie zim łagodnych czy wręcz ciepłych, oddzielających od siebie dłuższe serie zim chłodnych.

Najchłodniejszy podokres w rozpatrywanym okresie trwał 7 lat - od roku 1836 do roku 1842 , jego średnia temperatura jest równa $-2,73^{\circ} \mathrm{C}$. Wszystkie zimy w tym podokresie miały ujemną średnią temperaturę, trzy z nich były bardzo chłodne, z $\mathrm{PL}_{\mathrm{Z}}$ niższą od $-3^{\circ} \mathrm{C}(1838,1840,1841$; podokres 10 - tab. 4). Niewiele cieplejszy był podokres 19 trwający 10 lat $(1962-1971)^{10}$ o średniej temperaturze $-2,49^{\circ} \mathrm{C}$ i również wszystkich zimach o ujemnej temperaturze. W tym podokresie wystąpiła seria zim bardzo chłodnych i ekstremalnie chłodnych $\left(\mathrm{PL}_{\mathrm{Z}}<-3,0^{\circ} \mathrm{C}\right.$; lata: 1963 , 1964, 1969 i 1970).

Najcieplejszy podokres trwał 15 lat (nr 22; lata 1988-2002), jego średnia temperatura jest równa $+0,57^{\circ} \mathrm{C}$. Mimo wysokiej temperatury był to podokres mało stabilny. $\mathrm{W}$ podokresie tym wystąpiło 11 zim o temperaturze wyższej od $0^{\circ} \mathrm{C}$ i 4 zimy o temperaturze niższej od $0^{\circ} \mathrm{C}$, wśród tych ostatnich wyjątkowo surowa i długa zima roku 1996 o średniej temperaturze $-4,52^{\circ} \mathrm{C}$. Ekstremalnie ciepłe zimy tego podokresu wystąpiły w latach $1989\left(\mathrm{PL}_{\mathrm{Z}}=+2,71^{\circ} \mathrm{C}\right)$ i $1990\left(+3,35^{\circ} \mathrm{C}\right)$, ponadto $5 \mathrm{zim}$ „ciepłych” $\mathrm{w}$ tym podokresie miało średnią temperaturę w przedziale od $+1 \mathrm{do}+2^{\circ} \mathrm{C}$. Pozostałe podokresy ciepłe (3, 9 i 20; tab. 4) były krótkie, kilkuletnie, ich czas trwania zamyka się w granicach od 4 do 6 lat. Zdają się stanowić krótkie, ciepłe przerwy, między dłuższymi podokresami o przewadze surowych zim.

Występujące w całym szeregu podokresy poddano analizie skupień. Zastosowano metodę grupowania (aglomeracji) Warda, a jako miarę wiązania - odległości euklidesowe. Jako cechy opisujące zmienne, jakimi były podokresy, przyjęto zestawione w tab. 4 dane: średnią temperaturę zim w podokresie, jej odchylenie standardowe, liczbę lat tworzących podokres (długość podokresu), liczbę zim o ujemnej temperaturze w podokresie, liczbę zim o temperaturze dodatniej w podokresie, minimalną temperaturę zimy występującej w podokresie, maksymalną temperaturę zimy w podokresie $(7 \mathrm{cech})$. Dla wymuszenia grupowania w porządku chronologicznym dodano dwie dalsze cechy - rok wystąpienia temperatury minimalnej i rok wystąpienia temperatury maksymalnej w podokresie. Tak więc każdy podokres opisuje łącznie 9 cech. Wyniki grupowania przedstawia ryc. 9.

Procedura aglomeracji dzieli chronologiczny zbiór podokresów na dwie, znacznie różniące się części - od roku 1720 do roku 1857 (138 lat; podokresy od 1 do 11,

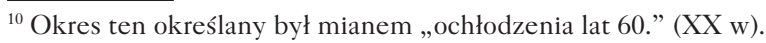




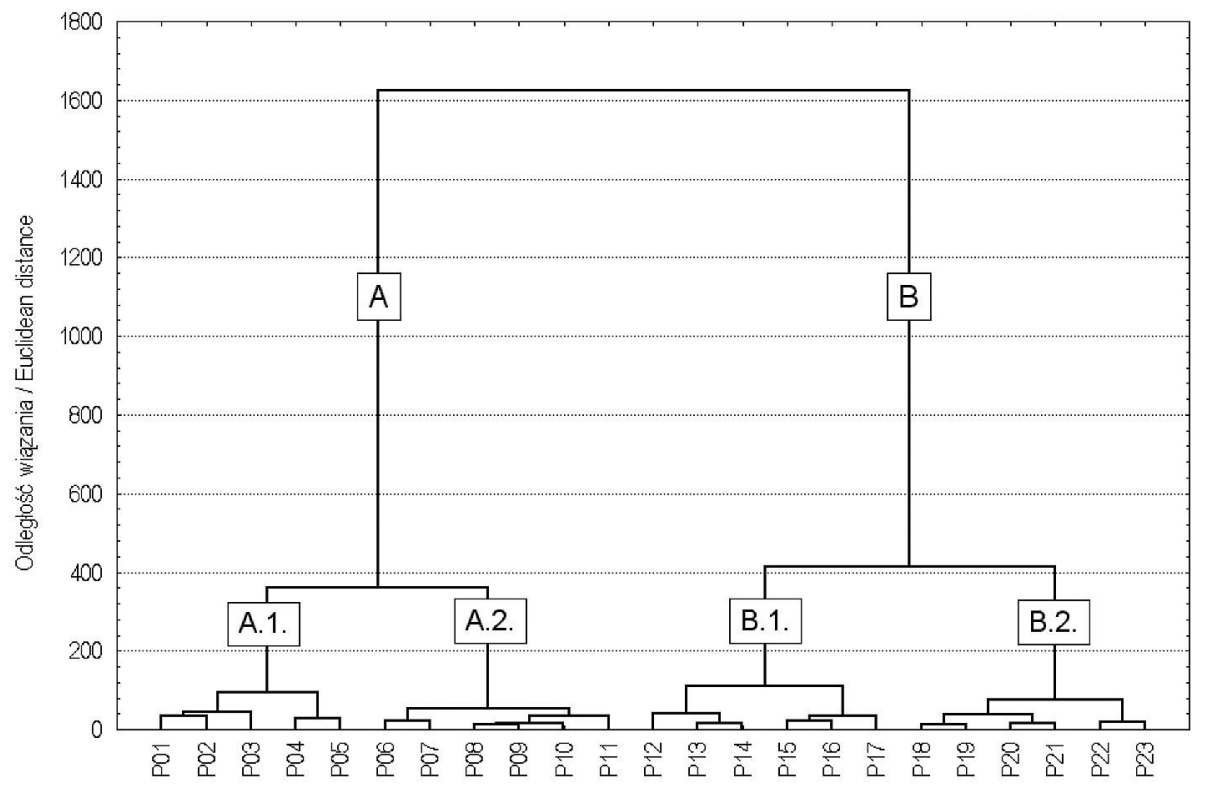

Ryc. 9. Wyniki grupowania (metoda Warda, odległości euklidesowe) podokresów o indywidualnych cechach struktury zim (tab. 4) w latach 1720-2015. P01, P02, P03, ..., - numery podokresów z tab. 4

Fig. 9. Grouping results (Ward's method, Euclidean distances) of sub-periods with individual winter structure features (see Table 4) in 1720-2015. P01, P02, P03, ..., - numbers of sub-periods from Table 4

dalej oznaczone jako epoka ${ }^{11}$ A) i od roku 1858 do 2015 (158 lat; podokresy od 12 do 23; dalej oznaczone jako epoka B). W obrębie każdej z epok procedura aglomeracji wyróżnia po dwie, stosunkowo podobne do siebie, podepoki: A1 (podokresy 1-5) i A2 (podokresy 6-11) oraz B1 (podokresy 12-17) i B2 (podokresy 18-23). Na najniższym szczeblu podziału taksonomicznego procedura aglomeracji wyróżnia 8 jednostek o różnym czasie trwania - następujących po sobie okresów, o indywidualnych, typowych cechach zachowania się zmienności obszarowej temperatury zim nad Polską. Lokują się w latach 1720-1765 (podokresy: 1, 2 i 3), 1766-1801 (podokresy 4 i 5), 1802-1825 (podokresy 6 i 7), 1826-1857 (podokresy: 8, 9, 10 i 11),

\footnotetext{
${ }^{11}$ Określenie ,epoka” zostało użyte ze względów na potrzebę odróżnienia skali czasu, a także ze względów porządkowych. Używane dalej określenie „epoka” nie ma tu znaczenia taksonomicznego ani związku z tak zwanymi ,epokami cyrkulacyjnymi”.
} 


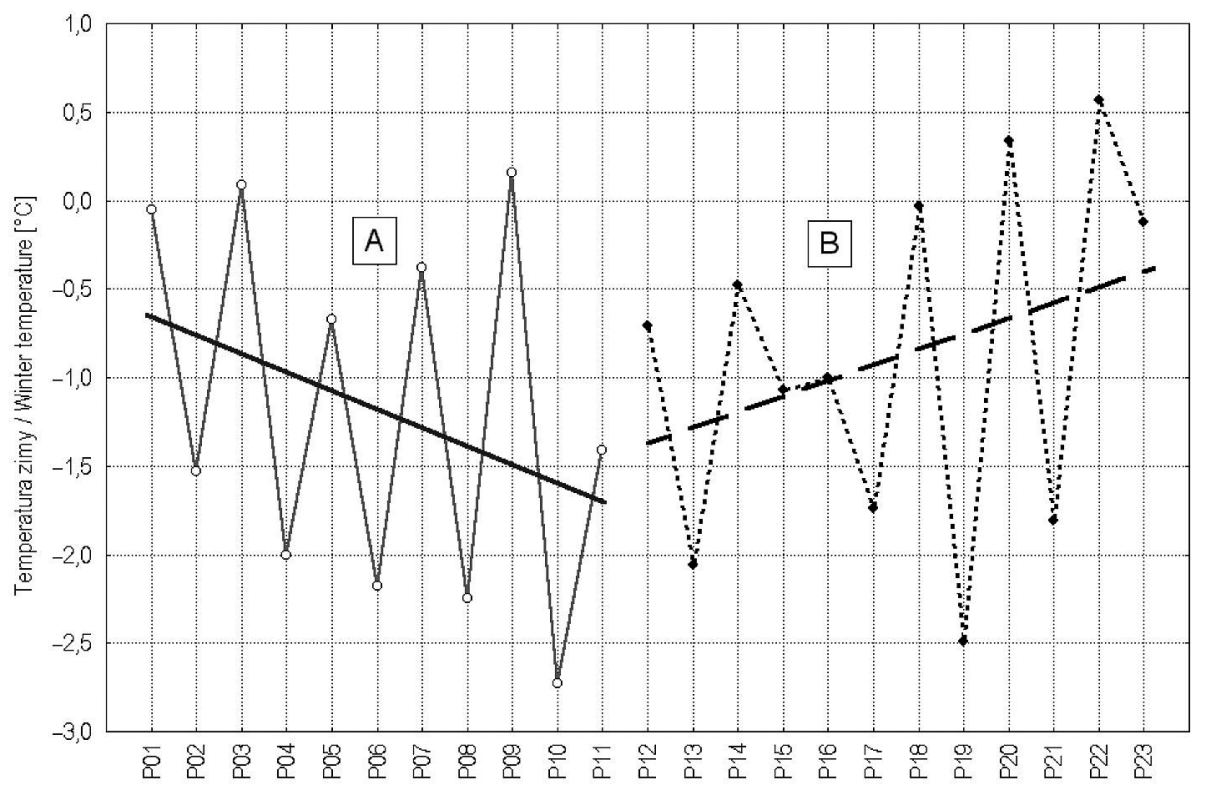

Ryc. 10. Zachowanie się średniej temperatury zim w podokresach P01 - P11, tworzących epokę A (1720-1857) i w podokresach P12 - P23, tworzących epokę B (1858-2015). Oznaczono linie tendencji zmian średniej temperatury zim w podokresach

Fig. 10. Mean winter temperature in the P01 - P11 sub-periods forming the A epoch (1720$1857)$ and in the P12 - P23 sub-periods forming the B epoch (1858-2015). The lines of the trend of changes in the average winter temperature in sub-periods are marked

1858-1914 (podokresy: 12, 13 i 14), 1915-1956 (podokresy: 15, 16 i 17), 1957-1987 (podokresy: 18, 19, 20 i 21) oraz 1988-2015 (podokresy 22 i 23).

Zasadniczą rolę w podziale na epoki odgrywa zróżnicowanie tendencji zmian średniej temperatury podokresów w każdej z nich, długości podokresów oraz charakter zmienności liczby przypadków wystąpienia zim „ciepłych” i „chłodnych” w czasie. W epoce A średnia temperatura zim w podokresach spada, w epoce B rośnie (ryc. 10). W podepoce A1 w każdym z podokresów występują zimy „ciepłe”, w podepoce A2 zimy „ciepłe” i „chłodne” w podokresach występują przemiennie. W podepoce B1 zimy „ciepłe” i „chłodne” występują przemiennie, w podepoce B2 w każdym z podokresów, z wyjątkiem podokresu 19, występują zimy ciepłe. Rysuje się w tym przebiegu coś na kształt symetrii, której osią są końcowe lata 50. XIX w. Można tu dodać, że monotonicznie rosnące w opisach cech podokresów numery lat 
z wystąpieniem w danym podokresie minimum i maksimum temperatury zim nie mają zasadniczego wpływu na podział zbioru podokresów na epoki.

Również struktura termiczna zim, rozumiana jako rozkład występowania częstości zim o danej temperaturze, w obu wyróżniających się epokach wykazuje poważne różnice. Zagadnienia tego nie rozwinięto w tym artykule, kwestię tę wyjaśnia ryc. 11 . Zwraca się uwagę tylko na to, że w epoce A dominują zimy, których średnia temperatura zamyka się w przedziałach między $-3^{\circ}$ a $-2^{\circ} \mathrm{C}$ oraz między $0^{\circ}$ a $+1^{\circ} \mathrm{C}$ (łącznie $43,5 \%$ czasu epoki), a w epoce B zimy, w których średnia temperatura mieści się w przedziale między $-1^{\circ}$ a $0^{\circ} \mathrm{C}$ oraz między $0^{\circ} \mathrm{a}+1^{\circ} \mathrm{C}(\sim 41,8 \%$ czasu epoki). Średnia temperatura zim w epoce A jest równa $-1,32( \pm 0,14)^{\circ} \mathrm{C}$, a w epoce B jest równa $-0,89( \pm 0,15)^{\circ} \mathrm{C}$. Różnica między tymi średnimi jest istotna statystycznie na poziomie $\mathrm{p}<0,05$ ( $\mathrm{p}=0,02$; test jednostronny).

Przeprowadzona analiza grupowania potwierdza niestacjonarność szeregu czasowego średniej obszarowej temperatury zim nad Polską oraz ujawnia moment przełomu w zmianach charakteru temperatury zim w rozpatrywanym okresie. Za ten moment można uznać przejście od zimy roku 1857 do zimy roku 1858. Patrząc szerzej, przełom następuje nie z roku na rok, ale w ciągu całego podokresu 12 (lata 1858-1885, pierwszy podokres epoki B), od którego zmieniła się w stosunku do podokresów poprzednich struktura termiczna zim. Zmiany te uwidoczniły się w zwiększeniu stopnia zmienności temperatury zim i wyraźnym wzroście frekwencji zim ciepłych oraz zim, których temperatura lokuje się w przedziale między $-1^{\circ}$ a $0^{\circ} \mathrm{C}$.
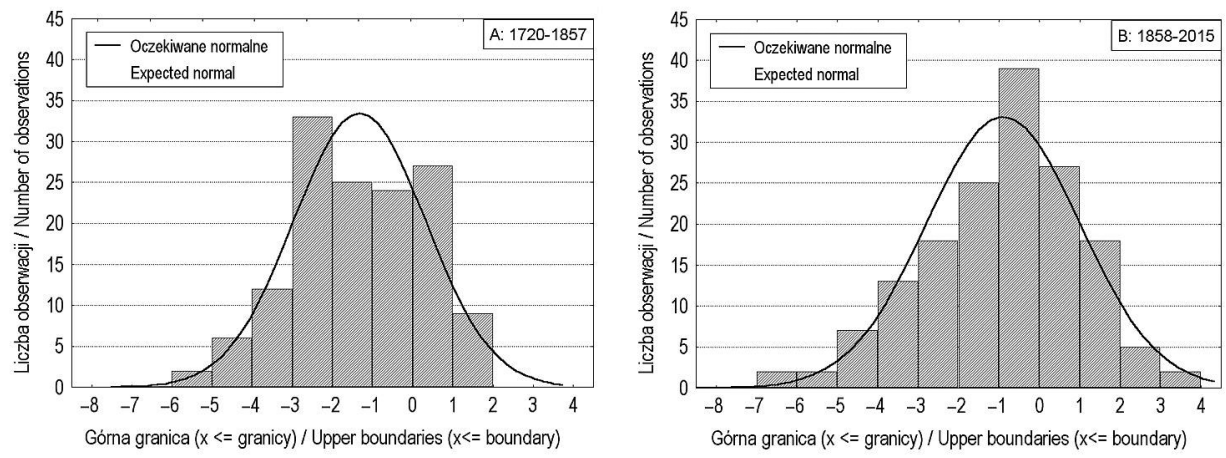

Ryc. 11. Rozkłady częstości występowania zim o danym przedziale temperatury w epoce A (1720-1857) i epoce B (1858-2015). Skale poziome i pionowe na obu częściach ryciny są identyczne

Fig. 11. Distributions of the frequency of occurrence of winters with a given temperature range in epoch A (1720-1857) and epoch B (1858-2015). The horizontal and vertical scales on both parts of the figure are identical 


\section{Dyskusja}

\section{Problem wykroczenia temperatury zim poza granice ,zmienności naturalnej” w końcu XX i na początku XXI w.}

Dyskusja nad uzyskanymi wynikami, siłą rzeczy, musi obejmować kilka odrębnych kwestii. Wobec formułowanej tezy o niebywale szybkim ocieplaniu się zim na półkuli północnej w ostatnim 30-leciu i wykroczeniu temperatury zim poza zakres ,zmienności naturalnej” pod wpływem antropogenicznego oddziaływania na klimat (np. Briffa i Osborn 2002; Karl i Trenberth 2003) wypada odnieść się do tej kwestii.

Przebieg średniej obszarowej temperatury zim nad Polską w rozpatrywanym, niemal 300-letnim okresie, wykazuje bardzo dużą zmienność, tak międzyroczną, jak i długookresową. Różnica średniej temperatury między zimą najcieplejszą (1990) a najchłodniejszą (1929) w tym okresie jest równa 9,5C. Przekłada się to jakościowo na różnicę między zimą „,bez zimy”, ze wszystkimi miesiącami o średniej temperaturze wyższej od $0^{\circ} \mathrm{C}$, w której występują dość często doby z maksymalną temperaturą dobową wyższą od $+10^{\circ} \mathrm{C}, \mathrm{z}$ co najwyżej kilkoma, nieciągłymi, krótkimi okresami występowania dób o średniej temperaturze niższej od zera i kilkunastoma przymrozkami w ciągu całej zimy, a zimą ekstremalnie mroźną, długą, ze wszystkimi miesiącami o ujemnej temperaturze powietrza, w której przynajmniej jeden miesiąc ma średnią miesięczną temperaturę w granicach między $-5^{\circ}$ a $-10^{\circ} \mathrm{C}$, a drugi temperaturę miesięczną niższą od $-10^{\circ} \mathrm{C}$, co oznacza, że minimalna temperatura dobowa przynajmniej w kilkunastu dniach tych najchłodniejszych miesięcy jest niższa od $-20^{\circ},-22,5^{\circ} \mathrm{C}$.

Jak już wspomniano, trend liniowy średniej obszarowej temperatury zim w latach $1720-2015$ jest słaby i nieistotny statystycznie $\left(+0,0020( \pm 0,0012)^{\circ} \mathrm{C} \cdot \mathrm{rok}^{-1}\right.$, $\mathrm{p}=0,103)$. Jest sprawą powszechnie znaną, że wartość trendu jest bardzo silnie uzależniona od wartości w początkowej części szeregu, w którym trend ten się oblicza. Przebieg średniej obszarowej temperatury zim na obszarze Polski $\left(\mathrm{PL}_{z}\right)$ w rozpatrywanym okresie rozpoczyna się od relatywnie ciepłego i niestabilnego podokresu 1 (1720-1737). Ocieplenie zim w całej Europie w tym okresie potwierdza rekonstrukcja Luterbachera i in. (2006), a w obszarze nadbałtyckim rekonstrukcja temperatury przedstawiona w monografii The BACG II (Niedźwiedź i in. 2015, ich ryc. 3.8). Wystąpienie bardzo ciepłych zim w latach 20-30. XVIII w., z najcieplejszą zimą w roku $1724^{12}$ odnotowano w pobliskich Czechach (Dobrovolny i in. 2010). W przybliżeniu w tym samym okresie zauważa się w rekonstrukcji temperatury lata w Tatrach (Niedźwiedź 2004) wystąpienie okresu cieplejszego od średniej.

${ }^{12}$ Zrekonstruowana średnia obszarowa temperatura zimy roku 1724 w Polsce jest równa $+1,13^{\circ} \mathrm{C}$. 
Wskazuje to, że nastąpił w tym okresie nad Polską nie tylko wzrost temperatury zimy, ale i znaczący wzrost temperatury rocznej.

Wystąpienie wysokich wartości temperatury zim w początkowej części szeregu oraz w kilku dalszych podokresach jest przyczyną tego, iż mimo że w końcowej części szeregu występują zimy o najwyższej, wcześniej nieodnotowanej temperaturze, trend liniowy w rozpatrywanym 296-leciu jest słaby i nieistotny. Jego prawdziwa wartość mieści się gdzieś w zakresie między $+0,0008^{\circ} \mathrm{a}+0,0032^{\circ} \mathrm{C} \cdot \mathrm{rok}^{-1}$, co oznacza, że w ciągu 296 lat średnia obszarowa temperatura zimy nad Polską niewątpliwie wzrosła, ale wzrost ten mieści się między $\sim 0,24^{\circ} \mathrm{a} \sim 0,95^{\circ} \mathrm{C}$, co, jak na niemal 300 lat, nie wydaje się być wartością znaczącą.

W świetle uzyskanych wyników trudno zatem mówić o jakimś liczącym się wzroście średniej temperatury obszarowej zimy w całym rozpatrywanym okresie. Mając na względzie wartość średniej temperatury zim $\left(-1,09^{\circ} \mathrm{C}\right)$ i jej odchylenia standardowego $\left(1,80^{\circ} \mathrm{C}\right)$, nieistotny, słaby trend dodatni oraz rozkład odchyleń od średniej w całym szeregu niewykraczający poza granice $\pm 3 \sigma$, można twierdzić, że zmienność temperatury obszarowej zim w rozpatrywanym okresie mieści się w granicach zmienności naturalnej.

Analiza amplitudy zmian temperatury zim w poszczególnych podokresach nie potwierdza tezy, że trwające od lat 60 . czy 80 . XX w. tempo wzrostu temperatury jest większe, niż miało to kiedykolwiek miejsce w poprzednich stuleciach (patrz np. Karl i Trenberth 2003; Przybylak 2008, 2016). W latach 1963-1990 trend średniej obszarowej temperatury zim ${ }^{13}$ jest równy $+0,105^{\circ} \mathrm{C} \cdot$ rok $^{-1}$, a w latach $1970-1990$ trend wzrostu temperatury zim wyniósł $+0,057^{\circ} \mathrm{C} \cdot \mathrm{rok}^{-1}$. Szybsze lub równie szybkie i o podobnej amplitudzie jak w okresie 1981-2000 (trend $+0,082^{\circ} \mathrm{C} \cdot \mathrm{rok}^{-1}$ ) wzrosty średniej obszarowej temperatury zim w Polsce występowały wielokrotnie w czasie epizodów szybkich zmian temperatury. Jako przykłady można wymienić choćby lata 1784-1798 (trend $+0,235^{\circ} \mathrm{C} \cdot$ rok $^{-1}$ ), 1808-1825 (trend $+0,192^{\circ} \mathrm{C} \cdot$ rok $^{-1}$ ) czy okres lat 1886-1914, odpowiadający podokresom 13 i 14, w którym w ciągu 29 lat nastąpił powolny, ale konsekwentny wzrost średniej temperatury zim, z temperatury $\sim-3^{\circ} \mathrm{C}$ w latach 1886-1889 do $\sim 1^{\circ} \mathrm{C}$ w latach 1910-1914 (trend równy $+0,090^{\circ} \mathrm{C} \cdot \mathrm{rok}^{-1}$, $\mathrm{p}<0,004)$.

W całym rozpatrywanym okresie wystąpił szereg epizodów silnych spadków i silnych wzrostów temperatury zimy o czasie trwania od kilku do kilkunastu, dwudziestu kilku lat (ryc. 7 i 8), co czyni, że dla badanego 296-letniego okresu typowa jest znaczna amplituda zmian, na tle których ostatni okres wzrostu temperatury zim

\footnotetext{
${ }^{13}$ Wybrane lata graniczne, dla których podaje się wartości trendów, wyznaczają okresy od momentu wystąpienia lokalnych minimów (zima 1963 r.; $\mathrm{PL}_{\mathrm{Z}}=-6,11^{\circ} \mathrm{C}$, zima $1970 \mathrm{r}$; $\mathrm{PL}_{\mathrm{Z}}=-4,43^{\circ} \mathrm{C}$ ) do momentu osiągnięcia przez temperaturę zimy historycznego maksimum (1990; $\left.\mathrm{PL}_{\mathrm{Z}}=+3,35^{\circ} \mathrm{C}\right)$. Na okres 1981-2000 przypada wzrost temperatury zim z głębokiego ochłodzenia (1985, 1987), a następnie stabilizacja na nowym wyższym poziomie, po skokowym wzroście w latach 1988-1990 (ryc. 5).
} 
następujący na przełomie XX i XXI w. nie jest niczym szczególnym. Jedynym, rzeczywistym wyróżnikiem tego okresu jest to, że w latach 1989, 1990 i 2007 wystąpiły najwyższe, wcześniej nienotowane średnie wartości temperatury zimy. Od wystąpienia maksimum (lata 1989-1990) do roku 2015 temperatura zim powoli obniża się, w jej przebiegu występuje nieistotny trend ujemny $\left(-0,036^{\circ} \mathrm{C} \cdot \mathrm{rok}^{-1}\right)$.

\section{Przedstawiony przebieg temperatury zim a rekonstrukcje wcześniejsze}

Między wcześniej prezentowanymi w literaturze rekonstrukcjami temperatury nad obszarem Polski a szeregiem $\mathrm{PL}_{\mathrm{z}}$ rysują się pewne różnice. Dla uwidocznienia tych różnic obliczono średnie dekadowe, które zestawiono w załączniku 2, co pozwala na porównanie ich przede wszystkim z szacunkami temperatury zim z licznych prac Przybylaka (2006, 2008, ..., 2016) i Brazdila i in. (2010), których rozdzielczość czasowa jest mniejsza i w których najczęściej operuje się średnimi dekadowymi. Dodatkowo załącznik 2 zawiera najważniejsze statystyki, charakteryzujące reżim termiczny poszczególnych dekad. Średnią temperaturę zim w poszczególnych dekadach, jako odchylenie od średniej dekadowej z okresu 1721-2010 (29 dekad) oraz granice odchyleń $\pm 1 \sigma$ od średniej dekadowej przedstawia ryc. 12 .

W okresie 1721-2010 wystąpiło 16 dekad o temperaturze niższej od średniej dekadowej $\left(-1,119^{\circ} \mathrm{C} ; \sigma=0,581\right)$ i 13 dekad o temperaturze wyższej od średniej dekadowej. Jeśli za dekady „wyjątkowo zimne” uzna się te, których średnia temperatura jest niższa od średniej dekadowej minus jedno odchylenie standardowe $\left(-1,700^{\circ} \mathrm{C}\right)$, to dekad takich w rozpatrywanym 290-leciu jest zaledwie 5. Cztery dekady występujące na przełomie XVIII i XIX w. (1771-1780, 1781-1790, 1801-1810 i 1811-1820) tworzą względnie ciągły, przerwany tylko dekadą 1791-1800 nieco cieplejszą od średniej, okres chłodny. Piątą dekadą, najchłodniejszą w całym 290-leciu, jest występująca w XX w. dekada 1961-1970 (ryc. 12). Ta ostatnia dekada w znacznej części pokrywa się z okresem nazywanym dawniej „ochłodzeniem lat 60. XX w.”, kiedy to nastąpił gwałtowny spadek temperatury w skali hemisferycznej. Żadna z najchłodniejszych dekad „wyjątkowo zimnych” nie przekracza granicy (średnia $-2 \sigma$ ), choć dekada 1961-1970 jest stosunkowo bliska tej granicy.

Przyjmując analogicznie jako dekady „wyjątkowo ciepłe” te z nich, których temperatura dekadowa przekracza granicę (średnia $+\sigma ;-0,538^{\circ} \mathrm{C}$ ), dekad to takich jest 7, a więc więcej od dekad „wyjątkowo zimnych”, i to, mimo nieco mniejszej frekwencji dekad o temperaturze wyższej od średniej. W XVIII w. wystąpiły dwie takie dekady (1721-1730, 1731-1740). W XIX w. dekady „wyjątkowo ciepłe” nie wystąpiły. Największa liczba, bo pięć dekad „wyjątkowo ciepłych”, występuje w XX w. Pojedyncza dekada (1911-1920) występuje na początku XX w., pozostałe cztery tworzą nieprzerwany ciąg rozpoczynający się od dekady 1971-1980, a kończący na 


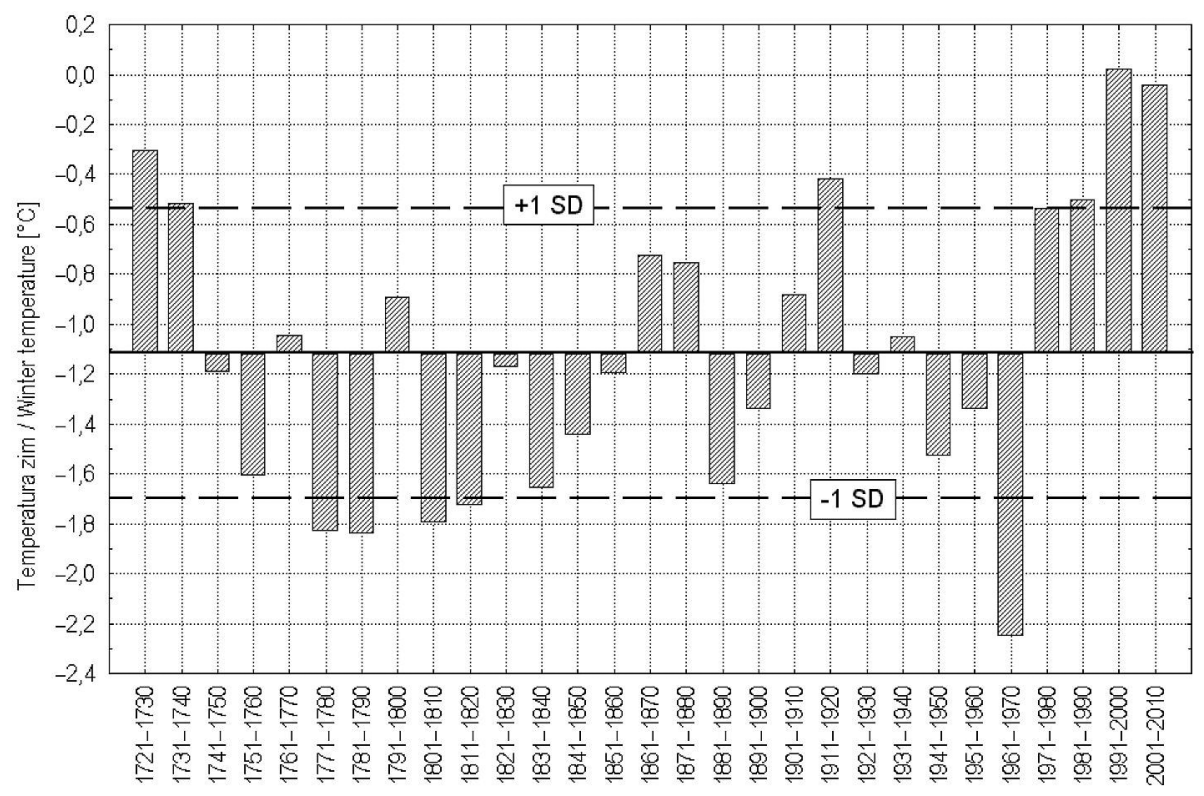

Ryc. 12. Przebieg średniej temperatury zim w kolejnych dekadach przedstawionych jako odchylenia od średniej dekadowej $\left(-1,119^{\circ} \mathrm{C}\right)$ z okresu $1721-2010$. Oznaczone zakresy odchyleń $\pm 1 \sigma$ od średniej dekadowej

Fig. 12. Average temperature course of winters in the following decades, presented as deviations from the decade average $\left(-1.119^{\circ} \mathrm{C}\right)$ from the period $1721-2010$. Ranges of deviations $\pm 1 \mathrm{SD}$ from the decade average are marked

dekadzie 2001-2010². Również temperatura żadnej dekady „wyjątkowo ciepłej” nie przekracza progu (średnia $+2 \sigma$ ), chociaż dwie ostatnie dekady do tej granicy się zbliżają (1991-2000 i 2001-2010; wartości standaryzowane +1,960 i +1,850 odpowiednio).

Tak więc w XX w. wystąpiły zarówno najchłodniejsze, jak i najcieplejsze dekady w rozpatrywanym okresie. Również w tym samym wieku wystąpiły zarówno zimy najchłodniejsze, jak i najcieplejsze. Nie zmienia to faktu, że właśnie w XX w. średnia temperatura zim jest najwyższa i widoczny jest wyraźny wzrost temperatury zim, co znajduje swoje przełożenie również na średnie dekadowe.

W pracach Przybylaka (Przybylak i in., 2004; Przybylak 2006), opartych na opisowych danych historycznych, a następnie interpretowanych klimatycznie, oraz danych

\footnotetext{
${ }^{14}$ Symptomatyczne jest to, że w tych najcieplejszych dekadach końca XX w. wystąpiły surowe zimy o niskiej temperaturze średniej (załącznik 2 i ryc. 5).
} 
dendrochronologicznych, określa się wystąpienie „dłuższego okresu” ochłodzenia, przypadającego na lata 1721-1820 z anomaliami temperatury zimy z reguły poniżej $-2^{\circ} \mathrm{C}$. Nawet uwzględniając poprawkę na odmienny okres uśredniania temperatury zimy (12-02), rekonstruowane przez autorów średnie dekadowe dla wymienionego stulecia są wyższe, a wymieniony okres pod względem termicznym był daleko niejednolity. Bardzo „ciepłe” były w nim dekady $1721-1730\left(-0,304^{\circ} \mathrm{C}\right)$ i $1731-1740$ $\left(-0,515^{\circ} \mathrm{C}\right.$; załącznik 2$)$, relatywnie „ciepłe” w tym okresie były dekady $1761-1770$ $(-1,047)$ i $1791-1800\left(-0,890^{\circ} \mathrm{C}\right)$. W wymienionym przez Przybylaka okresie 1721-1820 według rezultatów uzyskanych przez autorów (ryc. 12) wyraźnie chłodniejsze od średnich były dekady $1751-1760\left(-1,610^{\circ} \mathrm{C}\right), 1771-1780$ i 1781-1790 $\left(-1,831 \mathrm{i}-1,842^{\circ} \mathrm{C}\right.$ odpowiednio) a także dekady $1801-1810$ i $1811-1820(-1,797$ $\mathrm{i}-1,727^{\circ} \mathrm{C}$ ), tworząc dwa, względnie zwarte okresy zim bardziej surowych (wyjątkowo zimne dekady) w latach 1771-1790 i 1801-1820.

W świetle wyników badań autorów granice „najchłodniejszego stulecia” powinny zostać przesunięte na okres nieco późniejszy - od dekady 1751-1760 do dekady 1841-1850. Ten okres charakteryzuje się wystąpieniem w nim tylko dwu dekad nieznacznie cieplejszych od średnich dekadowych, wszystkie pozostałe dekady mają temperaturę niższą od średniej dla całego okresu, w tym występują w nim cztery dekady „wyjątkowo zimne”, średnia temperatura dekadowa zim była równa $-1,28^{\circ} \mathrm{C}$ (ryc. 12). Również liczba zim ciepłych występujących w stuleciu 1751-1850 (23/100 lat) jest mniejsza od przeciętnej dla całego rozpatrywanego okresu ( 29/100 lat).

W cytowanych pracach Przybylaka (2006, 2011, 2016) i Przybylaka i in. (2001, 2014a), a także Niedźwiedzia i in. (2015) za okres występowania najchłodniejszych zim w całym badanym okresie wskazuje się dekadę $1741-1750, \mathrm{z}$ anomalią $-4,1^{\circ} \mathrm{C}$. Wartość temperatury dekadowej obliczona $\mathrm{z}$ wartości $\mathrm{PL}_{\mathrm{Z}}$ dla tej samej dekady jest równa $\sim-1,2^{\circ} \mathrm{C}$ (dokładnie $-1,196^{\circ} \mathrm{C}$ ), co daje anomalię równą $-0,11^{\circ} \mathrm{C}$ w stosunku do średniej $\mathrm{PL}_{\mathrm{Z}}$ dla całego okresu badań $1720-2015$, a $-0,08^{\circ} \mathrm{C}$ w stosunku do średniej dekadowej temperatury zim $\left(-1,119^{\circ} \mathrm{C}\right.$; lata $\left.1721-2010\right)$. Trudno w świetle tych ocen przyjąć, aby dekada 1741-1750 wyróżniała się czymś szczególnym. Według rekonstrukcji autorów była to niewątpliwie dekada chłodna, w czasie jej trwania wystąpiło 9 zim „chłodnych”, z najchłodniejszą $\left(-2,51^{\circ} \mathrm{C}\right)$ zimą w roku 1747 i jedną tylko zimą „ciepłą” $\left(+0,57^{\circ} \mathrm{C}\right)$ w roku 1750 , ale pod względem termicznym bardzo niewiele odbiegającą od średniej z całego okresu. W XVIII i XIX w. było kilka dekad zdecydowanie chłodniejszych od dekady 1741-1750 (załącznik 2).

Rozpatrując różnice między średnimi dekadowymi, trzeba jednak zdawać sobie sprawę z tego, że porównywane wartości są w pewnym sensie „losowe”, wobec nie zawsze jednakowego sposobu zliczania średnich dekadowych w cytowanych pracach. Wystarczy przesunąć początek zliczania dekad z roku 1721, tak jak przyjmuje się w statystykach przedstawionych w załączniku 2, na rok 1720 będący początkiem szeregu, aby obliczane średnie dekadowe temperatury zim $\left(\mathrm{T}_{\text {dek }}\right)$ znacznie różniły się 
od przedstawionych. Przykładowo, jeśli policzy się średnią dla dekady lat 1941-1950,

to $\mathrm{T}_{\text {dek }}$ jest równa $-1,529^{\circ} \mathrm{C}$, jeśli policzy się $\mathrm{T}_{\text {dek }} \mathrm{z}$ lat $1940-1949$, będzie ona równa $-1,905^{\circ} \mathrm{C}$. Taka różnica, rzędu $0,4^{\circ} \mathrm{C}$ w średnich dekadowych temperatury zim, zmienia w zasadniczy sposób hierarchię (rangę) stopnia „ostrości zim” w dekadach.

\section{Rola cyrkulacji atmosferycznej w kształtowaniu zmienności temperatury zim i problem granicy między Małą Epoką Lodową a okresem klimatu współczesnego}

Następną kwestią, którą, jak się wydaje, należy poddać dyskusji, jest problem przyczyn długookresowych zmian temperatury zim w rozpatrywanym okresie. Temperatura zim nad Polską jest determinowana w pierwszym rzędzie przez występującą w czasie ich trwania cyrkulację atmosferyczną (Degirmendžić 2003; Kożuchowski 2000, 2003, 2004, 2011). Podobnie wartość MIE, która jest tu predyktorem do szacowania średniej temperatury obszarowej, uwarunkowana jest przez występującą w okresie całej zimy cyrkulację atmosferyczną (np. Koslowski i Glaser 1999; Omstedt i Chen 2001; Marsz i Styszyńska 2005; Lehmann i in. 2011). Tak więc zarówno główny predyktor do rekonstrukcji temperatury zimy, jak i temperatura zimy zmieniają się pod wpływem działania tego samego czynnika.

„Ciepłe” zimy stanowią najczęściej efekt wzrostu, znacznie powyżej przeciętnej, częstości napływów (adwekcji) powietrza z zachodu i południowego zachodu (Degirmendžić 2003; Kożuchowski 2003, 2004, 2011), ale również, choć w mniej licznych przypadkach, występują przy wyraźnie większej od średniej częstości napływów z południa. Ciepłe zimy mogą więc rejestrować występowanie intensywnej cyrkulacji strefowej o adwekcjach z sektora od W do SW, ale też intensywnej cyrkulacji południkowej o adwekcjach z sektora $S W$ do $S$. Występowanie cyrkulacji strefowej z napływami z sektora wschodniego w czasie ciepłych zim jest wykluczone.

Zimy „chłodne” stanowią skutek wzrostów częstości napływów z sektora północnego i wschodniego, rzadziej - północo-wschodniego (Degirmendžić 2003), a także sytuacji blokadowych z centrum nad Skandynawią/Bałtykiem i/lub Polską (Kożuchowski 2004), w których występuje długotrwała sytuacja antycyklonalna (bezadwekcyjna). Wymienione kierunki adwekcji powodujące ochłodzenie i sytuacje antycyklonalne mogą wystąpić tylko przy formach cyrkulacji południkowej.

Zimowe adwekcje ciepła, będące skutkiem napływu Powietrza Polarnego morskiego z zachodu, są konsekwencją zaistnienia dodatniej fazy Oscylacji Północnego Atlantyku (NAO). Wiązanie wystąpienia wszystkich przypadków wystąpienia zim ciepłych z dodatnią fazą NAO, a zim chłodnych w Polsce z ujemną fazą NAO jest jednak daleko idącym uproszczeniem. Związki między wartościami indeksu NAO a temperaturą powietrza nad Polską i Bałtykiem oraz MIE są niestacjonarne (patrz np. Omstedt i Chen 2001, również Marsz 2006). Oznacza to, że temperatura zimy 
nie określa jednoznacznie znaku i wartości zimowego indeksu NAO (Hurrell 1995) w czasie jej trwania ${ }^{15}$. Występują „,ciepłe” zimy przy ujemnych wartościach wskaźnika NAO i „chłodne” zimy przy dodatnich wartościach wskaźnika ${ }^{16}$.

Można przyjąć, że średnia temperatura zim w podokresach określonych mianem „stabilnych” rejestruje przeważający charakter (typ) cyrkulacji atmosferycznej w czasie ich trwania. Tym samym temperatura zim w podokresach stabilnych chłodnych $(2,4,6,8,10,11,13,15,17,19$ i 21) była kształtowana przez przewagę adwekcji z sektorów od północnego do wschodniego lub bezadwekcyjnych sytuacji blokadowych. Takie przyczyny wystąpienia niskiej temperatury są rezultatem występowania okresów cyrkulacji południkowej.

W epoce A (1720-1857) takich podokresów było 6 (2, 4, 6, 8, 10 i 11), a ich łączny czas trwania wynosił 90 lat, co stanowi $65 \%$ czasu epoki A. Pozostałe podokresy epoki A to podokresy niestabilne $(1,3,5,7,9)$ w czasie których obok zim chłodnych występuje znaczny odsetek zim ciepłych (tab. 4).

Podokres 1 rozpoczynający szereg (1720-1737), którego rzeczywisty czas trwania nie jest znany ${ }^{17}$, ma na tle pozostałych podokresów epoki A silnie nietypowe cechy. Następuje on krótko po Minimum Maundera (lata 1645-1715/1717; Ribes i Nesme-Ribes 1993; Balmaceda i in. 2007; Krivova i in. 2007), kiedy to, zgodnie z powszechnie występującą opinią, miało występować również termiczne minimum Małej Epoki Lodowej. Rekonstrukcja Luterbachera i in. (2004) wskazuje, że najniższa średnia temperatura zimy w Europie między rokiem 1500 a 2004 wystąpiła w 1709 r. (1708/1709), a więc w końcowej fazie Minimum Maundera i zaledwie 12 lat przed formalnym początkiem podokresu 1 . W podokresie 1 , którego średnia temperatura obszarowa zim nad Polską jest bliska $0^{\circ} \mathrm{C}\left(-0,05^{\circ} \mathrm{C}\right)$ i który trwał 18 lat, wystąpiło 12 zim o dodatniej temperaturze, z czego 5 zim z dodatnią temperaturą wystąpiło kolejno po sobie w końcowej części podokresu. Zarówno długość podokresu 1, jak i jego struktura wewnętrzna, czynią, że jest on bardziej podobny do ciepłych podokresów z końca szeregu (podokresów 22 czy 23), i raczej nie jest, przynajmniej pod względem typologicznym, częścią epoki A. Można zatem uważać, że podokres 1 stanowi dłuższy epizod wzrostu natężenia cyrkulacji strefowej zachodniej lub południkowej z napływami powietrza z sektora południowego, przerywający dominację cyrkulacji południkowej z adwekcjami nad Polskę powietrza z północy i wschodu.

\footnotetext{
${ }^{15}$ W licznych pracach (tu niecytowanych) dokonuje się ,rekonstrukcji” indeksu NAO, wykorzystując znane związki między indeksem NAO a temperaturą w czasach współczesnych (druga połowa XIX w. $\mathrm{i} /$ lub w XX w.), po czym z tych związków na podstawie historycznych zapisów temperatury powietrza odtwarza się wartości indeksów NAO. Wiarygodność rezultatów takich działań jest dyskusyjna.

${ }^{16}$ Wyjątkowo chłodna zima roku 1942 (średnia obszarowa $-5,40^{\circ} \mathrm{C}$ ) wystąpiła przy niewielkiej ujemnej wartości wskaźnika NAO równego -0,45, zima roku $1907\left(-2,95^{\circ} \mathrm{C}\right)$ przy dodatniej wartości wskaźnika NAO 2,06. W czasie ciepłej zimy roku 1936 (średnia obszarowa $+0,91^{\circ} \mathrm{C}$ ) indeks NAO był równy $-3,89$. ${ }^{17}$ Szereg temperatury zim rozpoczyna się od roku 1720 , jest to również formalny początek podokresu 1 . Nie wiadomo, czy zima roku 1720 nie była kontynuacją rozpoczętego już wcześniej niestabilnego podokresu.
} 
Rozważając strukturę podokresów niestabilnych w epoce A, wyłączając z nich niestabilny podokres 1 , zauważa się, że pozostałe podokresy niestabilne, ze znacznym udziałem form cyrkulacji strefowej zachodniej lub południkowej z dominującymi napływami z południa są krótkie, o czasie trwania od 4 do 12 lat (średnio 7-8 lat) i stanowią raczej epizody ociepleń przerywające ciągi zim chłodnych. Można zatem wnioskować, że w okresach zimowych lat 1738-1857 (epoka A bez podokresu 1) dominowała silna cyrkulacja południkowa, ze zdecydowaną przewagą adwekcji z sektorów północnego do wschodniego, z krótszymi epizodami nasilenia się cyrkulacji z sektora południowego, lub też przerywana tylko krótkimi epizodami zwiększonego, choć nigdy niedominującego, udziału cyrkulacji strefowej. Choć w epoce A nie wystąpiła zima o najniższej średniej temperaturze, to występuje w niej 7-letni podokres o najniższej średniej temperaturze zim w całym szeregu (podokres 10; 1836-1842; tab. 4). Pozwala to przyjąć, że cała epoka A mieści się w okresie Małej Epoki Lodowej.

Epoka B (1858-2015) rozpoczyna się od długiego (28 lat), niestabilnego podokresu 12 (1858-1885), w którym zaznacza się tylko nieznacznie przewaga zim chłodnych (16 zim chłodnych, 12 ciepłych). Typowe dla tego podokresu jest przemienne występowanie zim ciepłych i chłodnych - jedna (najczęściej) lub 2-3 kolejno następujące po sobie zimy ciepłe są oddzielone przez jedną (rzadziej) lub 2-3 zimy chłodne (częściej).

Dalszy przebieg temperatury zim w okresie epoki B charakteryzuje się narastającą niestabilnością, co wyraża się w silnym zróżnicowaniu temperatury zim w kolejno po sobie następujących podokresach i wypadkowym wzrostem temperatury zim. Sugeruje to, że w epoce B systematycznie wzrasta częstość cyrkulacji strefowej, a czas wystąpienia cyrkulacji południkowej z adwekcjami z północy i wschodu ulega skracaniu. Powstaje problem, czy między epokami A i B nastąpiła zmiana charakteru cyrkulacji atmosferycznej z przeważającej cyrkulacji południkowej na przeważającą cyrkulację strefową. Zmiana charakteru cyrkulacji mogłaby stanowić przyczynę zmiany charakteru termicznego zim i tym samym zadecydować o przejściu reżimu termicznego zim z charakteru chłodnego, do reżimu ciepłego, wyjaśniając jednocześnie przyczynę zakończenia się okresu Małej Epoki Lodowej.

Dla wyjaśnienia tej kwestii oszacowano wartości współczynników korelacji między temperaturą zim w poszczególnych podokresach a wartościami wskaźnika Oscylacji Północnego Atlantyku (NAO) w tych podokresach. Jako wskaźnik NAO wykorzystano zimowy (DJFM) stacyjny wskaźnik NAO CRU (Jones i in. 1997) z tego względu, że ma on najdłuższy, rozpoczynający się w 1824 r. szereg obserwacyjny. Uniemożliwia to co prawda, ze względu na brak danych, przeprowadzenie takich analiz dla pierwszych 7 podokresów (1720-1825), ale pozwala objąć analizą przynajmniej końcówkę epoki A (lata 1826-1856, podokresy od 8 do 11). Wobec zastrzeżeń sygnalizowanych wcześniej (patrz odnośnik 15) do tej analizy nie zastosowano rekonstruowanych wskaźników NAO. Wyniki analizy zestawione są w tab. 5. 
Tab. 5. Wartości współczynników korelacji (r) między temperaturą obszarową zim w podokresach 8-23 a zimowym wskaźnikiem NAO CRU (DJFM) oraz poziom ich istotności statystycznej (p). Wartości współczynników korelacji istotne statystycznie oznaczono pogrubionym drukiem

Table 5. Values of correlation coefficients (r) between the area temperature in winter in sub-periods 8-23 and winter NAO CRU (DJFM) and their statistical significance (p). The values of correlation coefficients being statistically significant are marked in bold

\begin{tabular}{|c|c|c|c|c|c|}
\hline Podokres & Lata & $\begin{array}{c}\text { Liczba lat } \\
\text { w podokresie } \\
(\mathrm{n})\end{array}$ & $\begin{array}{c}\text { Liczba zim } \\
\text { ciepłych } \\
\text { w podokresie }\end{array}$ & $\mathrm{r}$ & $\mathrm{p}$ \\
\hline 8 & $1826-1831$ & 6 & 0 & 0,1830 & 0,729 \\
\hline 9 & $1832-1835$ & 4 & 3 & 0,6032 & 0,397 \\
\hline 10 & $1836-1842$ & 7 & 0 & 0,6632 & 0,104 \\
\hline 11 & $1843-1857$ & 15 & 2 & 0,4866 & 0,066 \\
\hline 12 & $1858-1885$ & 28 & 12 & $\mathbf{0 , 5 9 0 4}$ & 0,001 \\
\hline 13 & $1886-1897$ & 12 & 0 & $\mathbf{0 , 7 0 5 7}$ & 0,010 \\
\hline 14 & $1898-1914$ & 17 & 7 & 0,3521 & 0,166 \\
\hline 15 & $1915-1920$ & 5 & 0 & $\mathbf{0 , 9 9 0 1}$ & 0,001 \\
\hline 16 & $1921-1938$ & 18 & 4 & 0,4206 & 0,082 \\
\hline 17 & $1939-1956$ & 18 & 2 & $\mathbf{0 , 7 3 5 2}$ & 0,001 \\
\hline 18 & $1957-1961$ & 5 & 3 & $\mathbf{0 , 8 9 3 3}$ & 0,001 \\
\hline 19 & $1962-1971$ & 10 & 0 & 0,6255 & 0,053 \\
\hline 20 & $1972-1977$ & 6 & 4 & 0,2756 & 0,597 \\
\hline 21 & $1978-1987$ & 10 & 1 & $\mathbf{0 , 7 9 0 9}$ & 0,006 \\
\hline 22 & $1988-2002$ & 15 & 11 & $\mathbf{0 , 8 4 5 9}$ & 0,001 \\
\hline 23 & $2003-2015$ & 13 & 6 & $\mathbf{0 , 7 5 1 1}$ & 0,003 \\
\hline
\end{tabular}

Analiza zawartości tab. 5 wskazuje, że w końcowym odcinku epoki A nie ujawniają się istotne statystycznie korelacje między temperaturą zim w podokresach a indeksem NAO. Luterbacher i in. (1999), dokonując rekonstrukcji wskaźnika NAO w okresie od 1675 r., stwierdzili (ich ryc. 2), że występujące w XVIII w. odtworzone przez nich indeksy NAO miały w zdecydowanej większości lat ujemne znaki. Stopień objaśnienia związków między predyktorami, z których Luterbacher i in. (1999) rekonstruowali indeks NAO, w tym okresie był niski ( $\mathrm{r}^{2}$ od $\sim 0,25$ do $\sim 0,4$ ), co wyjaśnia, że dokładność rekonstrukcji nie może być duża. Tym niemniej, we wnioskach cytowanej pracy znajduje się stwierdzenie, że nie przez cały rozpatrywany w tej pracy okres (1675-1990) NAO stanowiło dominujący wzorzec cyrkulacji atmosferycznej w atlantycko-europejskim sektorze cyrkulacyjnym.

Po raz pierwszy istotne korelacje między temperaturą zim nad Polską a indeksem zimowym NAO CRU pojawiają się w podokresie 12, stanowiącym pierwszy podokres 
epoki B. W kolejnych podokresach epoki B występowanie istotnych korelacji z NAO jest częste, choć nie jest ciągłe w czasie. Na 12 podokresów tworzących epokę B w 8 występują istotne korelacje między NAO a ich temperaturą (tab. 5).

Taki rozkład związków między NAO a temperaturą zim w okresie 1826-2015 nie rozstrzyga, ale jednak wyraźnie sugeruje, że NAO, jako postać cyrkulacji strefowej nie odgrywała w kształtowaniu temperatury zim jednakowej roli przez cały ten okres. Dopiero od długiego, stosunkowo ciepłego podokresu 12 (1858-1885; ryc. 10) ta postać cyrkulacji atmosferycznej „ujawniła” swoje działanie i aktywnie zaczęła wpływać na zmienność temperatury zim. Po podokresie 12 nastąpił w dwu dalszych podokresach - 13 i 14 (lata 1886-1914), po przejściowym spadku, wzrost temperatury zim z silnym trendem dodatnim $\left(+0,090^{\circ} \mathrm{C} \cdot \mathrm{rok}^{-1}\right)$, o którym wspomniano już wcześniej. Wypadkowy dodatni i istotny trend temperatury zim nad Polską $\left(+0,010^{\circ} \mathrm{C} \cdot \mathrm{rok}^{-1}, \mathrm{p}=0,020\right)$, mimo znacznych wahań temperatury w poszczególnych podokresach, utrzymuje się od roku 1886 do końca szeregu (2015 r.).

Oznacza to, że w czasie trwania epoki A, jednak bez podokresu 1, temperatura zim, zarówno „chłodnych”, jak i „,ciepłych”, kształtowała się pod wpływem cyrkulacji południkowej. Cyrkulacja zachodnia strefowa, którą można utożsamiać z NAO, zaczęła działać w podokresie 12, stopniowo wzmagając swoje natężenie i prowadząc konsekwentnie do wzrostu temperatury zim. Pozwala to przyjąć, że granicą między chłodnym okresem Małej Epoki Lodowej a okresem współczesnym są lata 1858-1885 (podokres 12), a przyczyną zmiany reżimu temperatury zim między tymi okresami jest zmiana charakteru cyrkulacji atmosferycznej. Podobną opinię, co do przyczyn końca MEL jeden z autorów wyraził już wcześniej (Marsz 2004). Również Omstedt i in. (2004) zmianę reżimu klimatycznego nad Bałtykiem, którą można utożsamiać z końcem Małej Epoki Lodowej, wiążą ze zmianą charakteru cyrkulacji atmosferycznej.

Za takim zespołem przyczyn prowadzących do zmiany reżimu cyrkulacyjnego kończącego Małą Epokę Lodową przemawiają i inne argumenty. Bjerknes (1965), opierając się na pracy Lamba (1964), rozważając przyczynę spadku temperatury powietrza w okresie Małej Epoki Lodowej, wysunął hipotezę, że ochłodzenie to miało swoją przyczynę w „,anomalnych” interakcjach między atmosferą a oceanem. Wobec napływu w niższe szerokości silnie wychłodzonych i wysłodzonych Powierzchniowych Wód Arktycznych doszło do silnego ochłodzenia wód w strefie umiarkowanej i ograniczenia w tej strefie wymiany ciepła między oceanem a atmosferą. Spowodowało to zmiany w położeniu centrów działania atmosfery - nastąpiło przesunięcie się na zachód centrum Wyżu Azorskiego i utworzenie się głębokiego niżu między Labradorem a południową Grenlandią. Niż Islandzki przestał istnieć, a tym samym przestało funkcjonować NAO, którego istotą jest antykorelacja ciśnienia atmosferycznego między Wyżem Azorskim a Niżem Islandzkim. 
Weryfikację hipotezy Bjerknesa (1965) przeprowadzili drogą modelowania van der Schrier i Barkmeijer (2005) oraz van der Schrier i Weber (2010). Ich materiałami wyjściowymi były historyczne dane o rozkładzie temperatury powierzchni Atlantyku Północnego z lat 1790-1820. Wyniki ich badań potwierdziły prawidłowość hipotezy postawionej przez Bjerknesa (1965) co do przyczyny silnego ochłodzenia wód Atlantyku Północnego w szerokościach umiarkowanych. Modelowanie warunków klimatycznych wykazało, że w latach 1790-1820 w rejonie Islandii zimą lokowało się rozmyte pole ciśnienia, główne centrum działania atmosfery w tym czasie stanowił głęboki niż z centrum nad Morzem Labrador. Wobec braku Niżu Islandzkiego funkcjonowanie NAO nie było możliwe, nad wschodnią częścią Atlantyku Północnego funkcjonowała cyrkulacja południkowa ${ }^{18}$.

Taki obraz pola barycznego, bez Niżu Islandzkiego i Wyżu Azorskiego, z centrum między Półwyspem Pirenejskim a Azorami, oraz bez funkcjonowania NAO, był najprawdopodobniej typowy dla całego okresu Małej Epoki Lodowej. Świadczą o tym m.in. zmiany SST na Morzu Sargassowym, która w czasie Małej Epoki Lodowej była istotnie niższa niż obecnie i w okresie poprzedzającym MEL (Keigwin 1996). Podobnie Kożuchowski (1994), który analizował serię MIE (lata 1720-1992) pod względem występujących w niej okresowości, nie znalazł w niej w okresie XVIII w. typowej dla NAO okresowości 7-8-letniej, której występowanie słabo zaznaczyło się w XIX w., a pełną siłę osiągnęło dopiero w XX w.

W latach 1790-1820, który to przedział czasu w całości mieści się w Małej Epoce Lodowej, najsilniejsze spadki temperatury według van Schriera i Barkmeijera (2005) wystąpiły w okresach zimowych (DJF) na obszarze wokółbałtyckim i Półwyspu Skandynawskiego (przeciętnie $<-1,75^{\circ} \mathrm{C}$ względem średnich z okresu 1971-2000) oraz na Nizinie Rosyjskiej $\left(<-2,0^{\circ} \mathrm{C}\right)$. Według tych samych autorów średnia temperatura powietrza w latach 1790-1820 w okresie letnim (JJA) była nad Polską przeciętnie wyższa o co najmniej $0,75^{\circ} \mathrm{C}$ w stosunku do średniej temperatury z lat 1971-2000. Oznacza to, że między okresem Małej Epoki Lodowej a okresem „klimatu współczesnego" (koniec XIX w. - XXI w.) musiały zajść nad obszarem Polski również znaczne zmiany w stopniu kontynentalizmu klimatu.

O ile najczęściej za datę kończącą Małą Epokę Lodową przyjmuje się rok 1850 (pełny przegląd poglądów na ten temat - patrz Obrębska-Starklowa 1997a, 1997b, a także Niedźwiedź i in. 2015), to zgodnie z wynikami tej pracy, w świetle zmian

\footnotetext{
${ }^{18}$ Funkcjonowanie „centrów działania atmosfery” (Rossby 1939), czyli klimatycznych niżów i klimatycznych wyżów, wbrew wyobrażeniom, nie jest stałe w czasie i przestrzeni. Zależy ono od rozkładu zasobów ciepła w wodach oceanów, które ulegają zmianom wraz ze zmianami natężenia cyrkulacji termohalinowej. Lehmann i in. (2011; ich ryc. 4) wykazali w latach 1958-2008 znaczne przemieszczanie się położenia centrów Niżu Islandzkiego i Wyżu Azorskiego, co stanowiło przyczynę zmian natężenia przepływów strefowych nad Europą i tym samym zmian charakteru termicznego zim nad basenem Morza Bałtyckiego i w konsekwencji - zlodzenia Bałtyku.
} 
temperatury zim, granicę tę należałoby przesunąć na koniec lat 80. XIX w. (po 1885 r.). Podobnie Niedźwiedź (2004), na podstawie badań dendroklimatycznych w Tatrach, charakteryzujących warunki ciepłej pory roku, widzi późniejsze zakończenie się Małej Epoki Lodowej, które datuje na rok 1895. Omstedt i in. (2004), badając zmiany rocznej temperatury powietrza nad Bałtykiem w okresie ostatniego 200-lecia, wyznaczają przejście z okresu Małej Epoki Lodowej do okresu klimatu współczesnego na „późne” lata XIX w., a przyczyn zmian reżimu temperatury dopatrują się również w zmianach charakteru cyrkulacji atmosferycznej.

\section{Rola zmiennej aktywności Słońca i wulkanizmu w kształtowaniu temperatury zim nad Polską w okresie ochłodzenia Małej Epoki Lodowej}

Przedstawione przez autorów tej pracy wnioski na temat przyczyn ochłodzenia w okresie Małej Epoki Lodowej, a więc i przyczyn częstego występowania niskiej temperatury zim nad Polską w XVIII i większej części XIX w., odbiegają od najczęściej wyrażanych opinii na ten temat. W literaturze przedmiotu dwie przyczyny ochłodzenia zaistniałego w czasie MEL wysuwane są na plan pierwszy - osłabienie aktywności słonecznej (np. Obrębska-Starklowa 1997a, 1997b; Mann i in. 1998; Waple i in. 2002; Eriksson i in. 2007; Steinhilber i Beer 2011; Breitenmoser i in. 2012) oraz działalność wulkaniczna (np. Bradley 1988; Obrębska-Starklowa 1997a; Crowley i in. 2008; Gao i in. 2008; Breitenmoser i in. 2012; Swingedouw i in. 2017). W obu kwestiach zdania badaczy są podzielone. Nie rozstrzygając w tym miejscu kwestii rzeczywistej roli obu wymienionych czynników, wypada jednak zwrócić uwagę na fakty.

Analiza zmian temperatury zim w Polsce, które nastąpiły po czterech największych wybuchach wulkanicznych, jakie miały miejsce w XIX i XX w., nie wskazuje, aby zima, która następuje bezpośrednio po silnych erupcjach wulkanicznych, ani też zimy, które następują z większym niż rocznym opóźnieniem, wykazywały istotny spadek temperatury. Rysuje się raczej pozornie paradoksalny obraz, że po wielkich wybuchach wulkanicznych temperatura obszarowa zim nad Polską rośnie (ryc. 13), co zdaje się przeczyć „zdrowemu rozsądkowi”, na który powołują się niektórzy badacze.

Wybuch wulkanu Tambora (kwiecień 1815), który doprowadził do spadku temperatury globalnej (,lato bez lata” w Europie i inne anomalie w Ameryce Północnej, patrz: Robock 2001, Luterbacher i Pfister 2015) nie zapisał się w przebiegu temperatury zim nad Polską. Zima, która nastąpiła po erupcji (1815/1816, datowana na rok 1816) była co prawda nieznacznie chłodniejsza od zimy ją poprzedzającej (ryc. 13), ale trzy następne zimy (1817, 1818 i 1819) były znacznie cieplejsze od pierwszej zimy po wybuchu. W dalszym przebiegu temperatury zim trudno dopatrzyć się jakiejś czytelnej reakcji na wybuch tego wulkanu. 

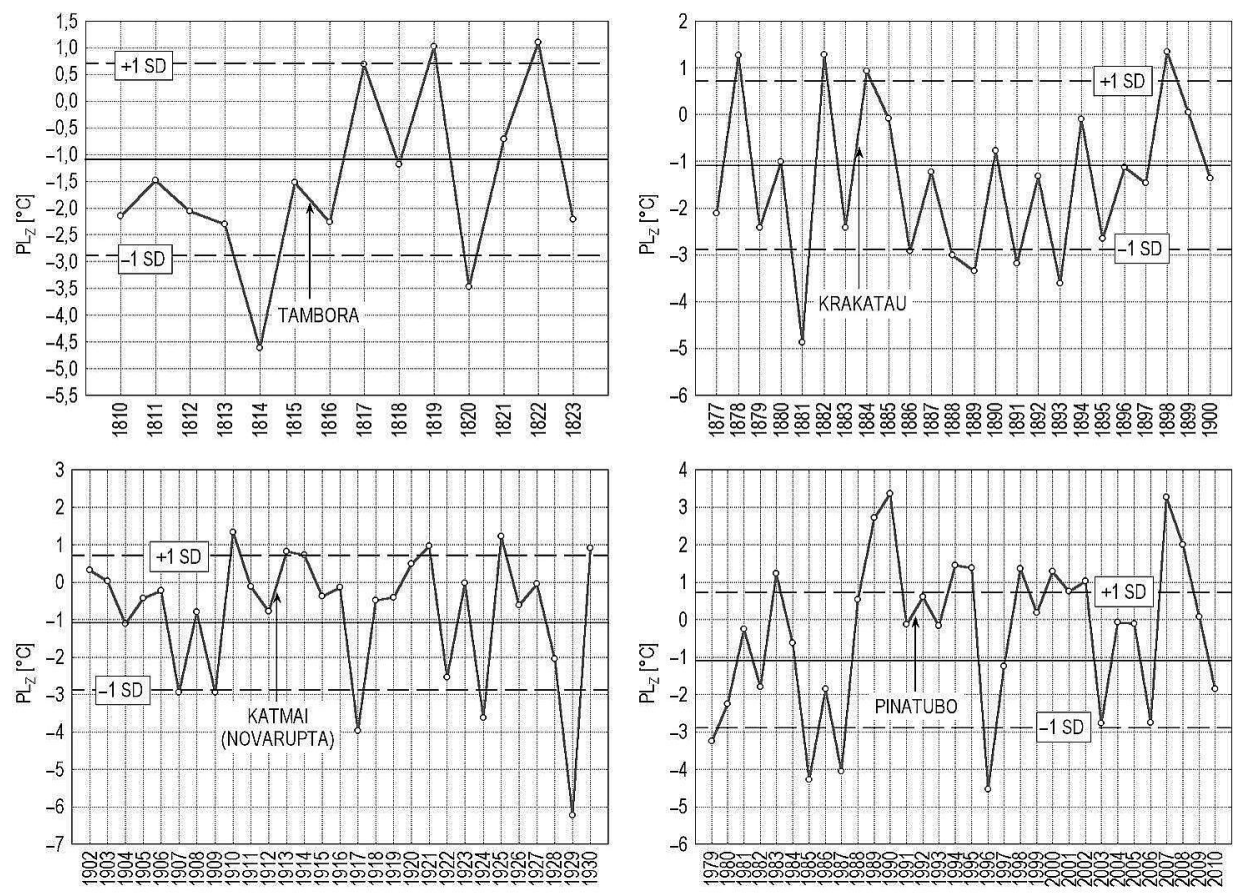

Ryc. 13. Przebieg średniej obszarowej temperatury zim w Polsce w latach poprzedzających i następujących po największych erupcjach wulkanicznych na półkuli północnej w XIX i XX w. (momenty erupcji oznaczone strzałkami: Tambora - kwiecień 1815 r., Krakatau - sierpień 1883 r., Novarupta (Katmai) - czerwiec 1912 r. i Pinatubo - czerwiec 1991 r.). Oznaczone: średnia wieloletnia (1720-2015) temperatura obszarowa zim na obszarze Polski (pogrubiona linia ciągła) oraz zakresy $\pm 1 \sigma$ temperatury zim

Fig. 13. Course of mean area winter temperature in Poland in the years preceding and following the largest volcanic eruptions in the Northern Hemisphere in the 19th and 20th centuries (moments of the eruption marked with arrows: Tambora - April 1815, Krakatau August 1883, Novarupta (Katmai) - June 1912 and Pinatubo - June 1991). Long-term mean (1720-2015) area temperature of winters in Poland (bold solid line) and ranges \pm 1 SD of winter temperatures are marked

Wybuch wulkanu Krakatau spowodował obniżenie temperatury lata na półkuli północnej o 1,2C (Bradley 1988). Nadchodząca po wybuchu Krakatau (sierpień 1883) zima w Polsce była wyjątkowo ciepła, cieplejsza o $\sim 1,8^{\circ} \mathrm{C}$ od średniej wieloletniej (ryc. 13). Ponad dwa lata po wybuchu Krakatau rozpoczęła się seria zim chłodnych, 
chłodniejszych od średniej. Były to lata 1886-1897, tworzące podokres 13, w którym nie wystąpiła ani jedna zima ciepła (tab. 4). Nie ma podstaw, aby uważać ochłodzenie zachodzące w tym podokresie jako reakcję temperatury zim na erupcję Krakatau. Temperatura zim w podokresie 13 jest bardzo silnie i wysoce istotnie skorelowana z przebiegiem indeksu NAO (tab. 5), który przybierał wartości ujemne. Podobne, stabilne okresy ochłodzeń zim zachodziły i wcześniej bez związku z erupcjami wulkanicznymi.

Po eksplozji wulkanu Novarupta (Katmai) na Alasce (czerwiec 1912), która uważana jest za najsilniejszą eksplozję wulkaniczną na półkuli północnej w XX w. (Hildreth i Fierstein 2012), również dwie kolejne zimy w Polsce $(1913,1914)$ były ciepłe, a ich temperatura znacznie przewyższała średnią wieloletnią. Dalszy przebieg temperatury zim nie sugeruje, aby wybuch ten wywierał opóźniony wpływ na temperaturę. Duże chwilowe spadki temperatury zim (epizody lat: 1917, 1924 i 1929) oddzielane są od siebie zimami cieplejszymi od normy, w tym zimami cieplejszymi o $1 \sigma$ od średniej wieloletniej.

Podobnie przedstawia się przebieg temperatury zim po wybuchu Pinatubo (czerwiec 1991), który spowodował obniżenie rocznej temperatury powietrza na półkuli północnej o $0,5-0,6^{\circ} \mathrm{C}$. Temperatura zimy, która nastąpiła po wybuchu (1992) była wyższa niż zimy poprzedzającej eksplozję, następnej zimy (1993) temperatura nieznacznie spadła, po czym dwie następne zimy (1994 i 1995) były wyjątkowo ciepłe. Groisman (1992) interpretuje wzrost temperatury zim w Europie Środkowej i Północnej, jaki nastąpił po wybuchu Pinatubo, jako klimatyczny skutek tego wybuchu.

Tak więc przyjmowanie „wulkanizmu”, jako przyczyny ochłodzeń zim jest bardziej wyrazem przekonań niż analizy materiału obserwacyjnego. Fischer i in. (2007) przeprowadzili analizę odpowiedzi klimatu Europy na wybuchy wulkaniczne w tropikach w ciągu połowy ostatniego tysiąclecia. Badacze ci wykazali, że reakcja temperatury powietrza w Europie na silne wybuchy wulkaniczne wykazuje sezonowe zróżnicowanie. W okresie letnim prowadzi to do silnego spadku temperatury, w okresie zimowym do wzrostu temperatury. Wzrost temperatury zimą zaznacza się przez dwie kolejne zimy po wybuchu. Przyczyną takiego stanu, zdaniem Fischera i in. (2007), ma być przejście po wybuchu wulkanicznym NAO/AO do fazy dodatniej. Ta ostatnia teza wydaje się być co najmniej dyskusyjna. Ważną natomiast konkluzją pracy Fischera i in. (2007) jest stwierdzenie, że wybuchy wulkaniczne nie doprowadzają na obszarze Europy do długookresowych zmian temperatury.

NAO w okresach, w których funkcjonuje Niż Islandzki, wykazuje względnie stałe i silne skorelowanie z temperaturą zim, a więc to, że indeks NAO/AO jest wysoki i również temperatura jest w ciągu 1-2 lat po erupcji wysoka, nie świadczy o tym, że zwiększona ilość aerozoli wulkanicznych w atmosferze steruje zmiennością NAO. Jest wiele zim, w których temperatura jest wysoka i wysoki jest również indeks 
NAO, a przed daną zimą przez kilka czy kilkanaście lat wcześniej poważniejszych erupcji wulkanicznych nie było.

Mechanizm ocieplenia zim na półkuli północnej, jaki następuje po wybuchach wulkanicznych, zachodzący z jednorocznym lub dwuletnim opóźnieniem, w zależności od szerokości geograficznej, na której nastąpiła erupcja, objaśnili wcześniej od Fischera i in. (2007) Robock i Mao (1992) oraz Robock (2000). Robock i Mao (1992) wykazali, że wybuchy wulkaniczne powodują po erupcji wulkanicznej wzrost temperatury jednej, a częściej dwu następujących po sobie zim w strefie szerokości umiarkowanych półkuli północnej. Na całej półkuli, a więc nie tylko w atlantycko-europejskim sektorze cyrkulacyjnym, gdzie funkcjonuje NAO. Przyczynę ocieplenia zim w szerokościach umiarkowanych i spadku temperatury zim w szerokościach subtropikalnych (głównie na Środkowym Wschodzie) po wybuchach wulkanicznych Robock i Mao (1992) oraz Robock (2000) widzą we wzroście temperatury w tropikalnej stratosferze (wpływ aerozolu wulkanicznego), co przez opisany przez nich układ dość skomplikowanych powiązań wymusza w czasie nadchodzącej zimy (nadchodzących zim) zwiększenie natężenia strumienia strefowego w szerokościach umiarkowanych. Do podobnych wniosków, dotyczących zmian temperatury powietrza zimą i mechanizmów tych zmian dochodzą Graft i in. (1993), modelując skutki wybuchu El Chichón i Pinatubo.

Rola zmian aktywności słonecznej w kształtowaniu zmienności klimatu, w tym i temperatury zim, dyskutowana jest od ponad stulecia, a prac podejmujacych ten temat są setki. Z tego względu przedstawienie poglądów na ten temat i ewentualna dyskusja z nimi nie jest tu możliwa. Zainteresowany czytelnik znajdzie ich przegląd w literaturze zestawionej w zbiorowej monografii Varenholta i Lüninga (2012).

Liczni autorzy wiążą występujące ochłodzenie w okresie Małej Epoki Lodowej ze zmniejszeniem aktywności Słońca, konkretnie z występującymi w MEL okresami silnego zmniejszenia się liczby plam słonecznych, co warunkuje obniżenie wartości stałej słonecznej. W okresie MEL wystąpiły dwa okresy skrajnie niskiej aktywności Słońca - Minimum Maundera (1645-1715 lub 1645-1717) i Minimum Daltona (1790-1830). Okres analizy temperatury zim w tej pracy obejmuje lata 1720-2015, a więc praktycznie można się odnieść tylko do związków między temperaturą obszarową zim w Polsce a aktywnością słoneczną w czasie Minimum Daltona.

W ujęciu „dekadowym” Minimum Daltona przypada na cztery dekady (patrz załącznik 2, ryc. 12), z których pierwsza (1791-1800) charakteryzuje się średnią temperaturą wyższą od średniej, dwie następne temperaturą znacznie niższą od średniej dekadowej, a ostatnia (1821-1830) nieznacznie niższą od średniej. Średnia wartość $\mathrm{PL}_{Z}$ dla całego rozpatrywanego, 296-letniego okresu jest równa $-1,09^{\circ} \mathrm{C}$ $(\sigma=1,80)$, w okresie $1790-1830$, czyli Minimum Daltona, jest równa $-1,35^{\circ} \mathrm{C}$ $(\sigma=1,75)$. Jest więc w Minimum Daltona temperatura zim nieco niższa (o $\left.0,26^{\circ} \mathrm{C}\right)$ niż w całym rozpatrywanym okresie. Testy różnic między średnimi wykazują jednak, 


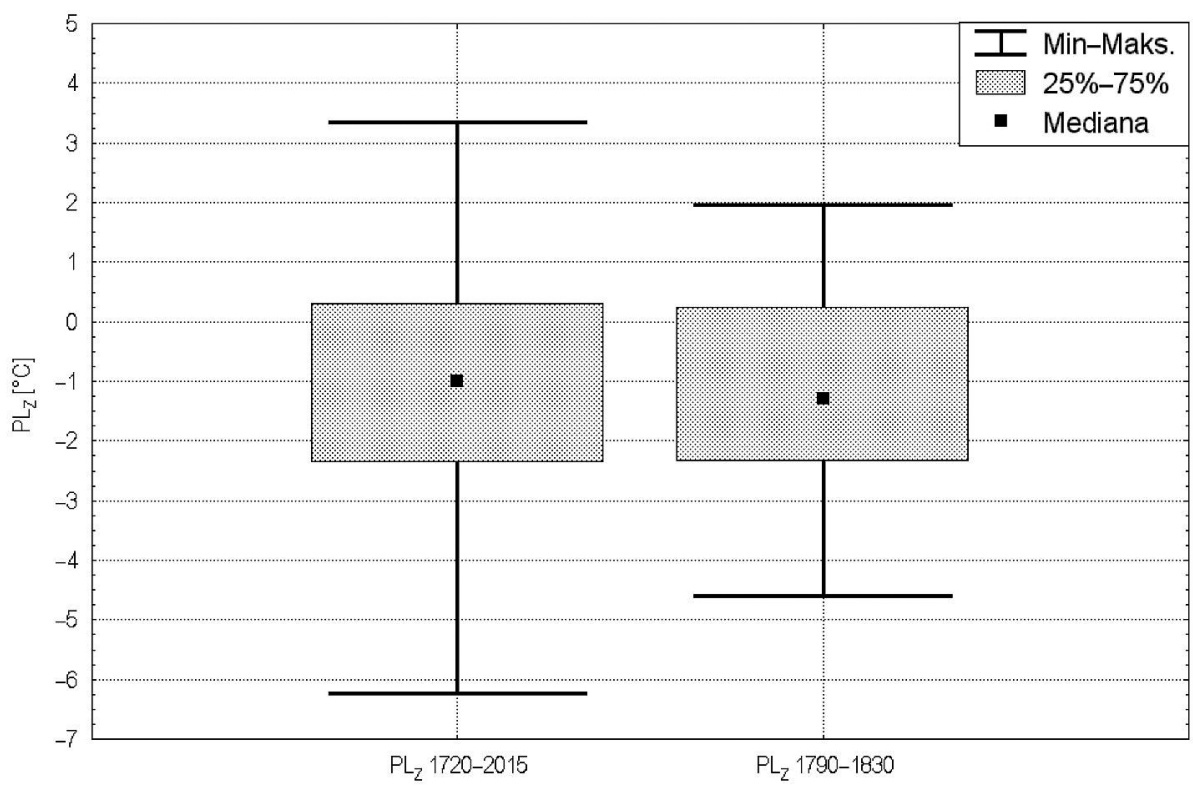

Ryc. 14. Zakresy zmienności temperatury zim w całym okresie $\left(\mathrm{PL}_{Z}\right.$ 1720-2015) i w okresie odpowiadającym Minimum Daltona $\left(\mathrm{PL}_{Z}\right.$ 1790-1830)

Fig. 14. Temperature variability ranges in the entire period $\left(\mathrm{PL}_{Z} 1720-2015\right)$ and in the period corresponding to the Dalton Minimum $\left(\mathrm{PL}_{\mathrm{Z}} 1790-1830\right)$

że różnica ta jest statystycznie nieistotna (p 0,105). Zakresy dwu środkowych kwartyli całego zbioru temperatury zim (1720-2015) i zbioru temperatury zim w okresie Daltona są niemal identyczne (ryc. 14), a zakres zmienności pierwszego kwartyla w okresie Minimum Daltona jest zdecydowanie mniejszy.

Analiza korelacji synchronicznych nie potwierdza, aby między przebiegami TSI

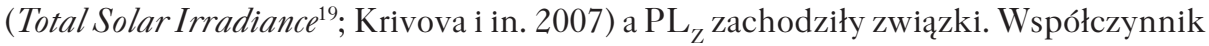
korelacji między przebiegami TSI i $\mathrm{PL}_{Z}$ w całym badanym okresie jest równy 0,087 $(\mathrm{p}=0,135)$, a w okresie $1790-1830$ równy $0,152(\mathrm{p}=0,344)$. Korelacje wzajemne obu szeregów z przesunięciami w granicach \pm 30 lat również nie wykazują wystąpienia istotnych statystycznie korelacji z przesunięciem czasowym. Wartości współczynników korelacji z przesunięciami czasowymi są niskie, nie przekraczają 0,1, a rozkłady w czasie asynchronicznych współczynników korelacji są chaotyczne.

${ }^{19}$ Źródło danych: http://lasp.colorado.edu/data/sorce/tsi_data/TSI_TIM_Reconstruction.txt (dostęp: 12.10.2017) 


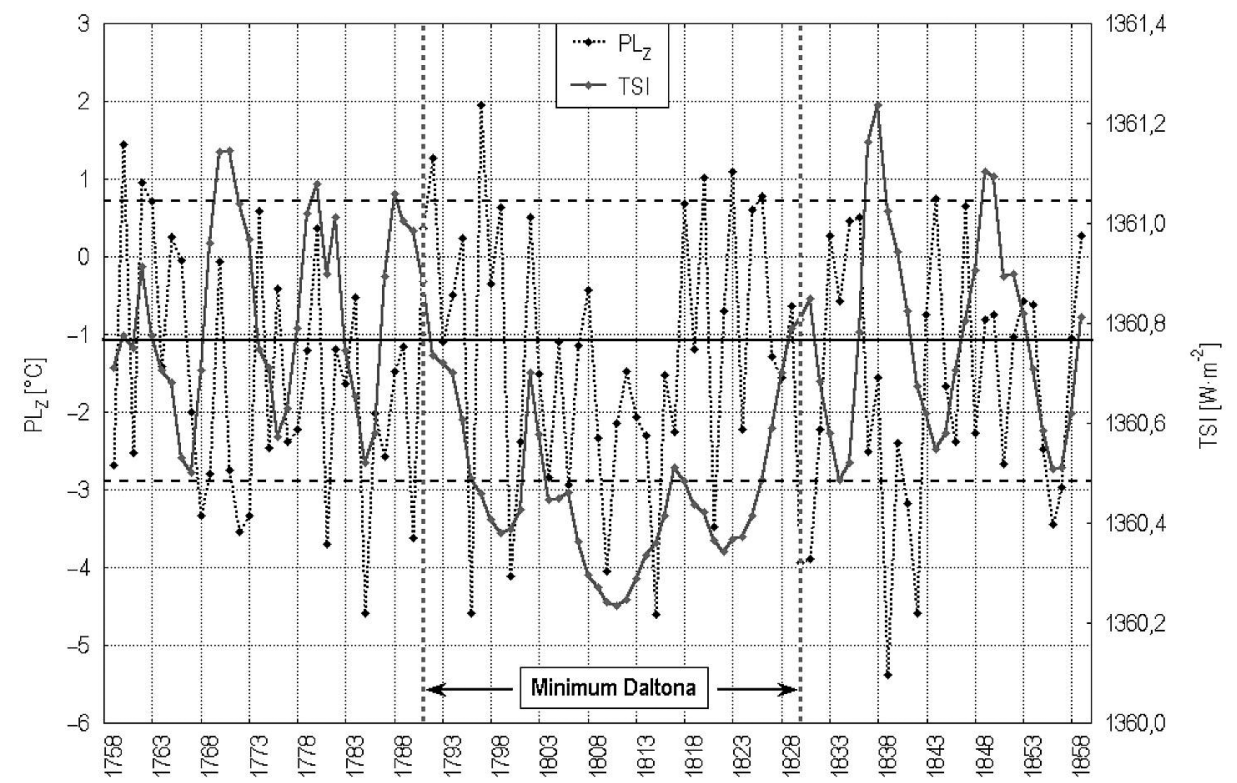

Ryc. 15. Przebieg średniej temperatury obszarowej zim w Polsce $\left(\mathrm{PL}_{\mathrm{Z}}\right)$ i wskaźnika TSI (Total Solar Irradiance; stałej słonecznej) w latach 1758-1858. Oznaczony okres występowania Minimum Daltona oraz średniej temperatury zim (pozioma linia ciągła) w całym rozpatrywanym okresie (1720-2015) i zakresy $\pm 1 \sigma$ (linie przerywane)

Fig. 15. Course of the mean area winter temperature in Poland $\left(\mathrm{PL}_{\mathrm{Z}}\right)$ and the TSI (Total Solar Irradiance) index in 1758-1858). The period of occurrence of the Dalton Minimum and the mean winter temperature (horizontal solid line) in the whole considered period (1720-2015) and ranges $\pm 1 \mathrm{SD}$ (dashed lines) are marked

Ryc. 15 przedstawia przebieg temperatury zim i przebieg wartości TSI w latach 1758-1858. Nietrudno zauważyć, że w trzyczęściowym okresie Minimum Daltona brak jakichkolwiek prawidłowości w przebiegu obu wielkości. W pierwszej (1790-1803) i ostatniej (1817-1830) części Minimum Daltona przeważają zimy cieplejsze od średniej, w środkowej o temperaturze niższej od średniej. W całym stuletnim przebiegu obu wielkości przedstawionym na tej rycinie zauważa się występowanie krótszych, kilkuletnich okresów, w których przebiegi te są w przybliżeniu zgodne w fazie, jak i okresy, w których przebiegi wykazują odwrócenie faz przebiegu. W przedstawionym na ryc. 15 stuleciu okres występowania najniższej temperatury zim przypada na ten sam okres, w którym aktywność Słońca jest najwyższa (1837-1839). 
Przedstawiony obraz zależności między TSI a $\mathrm{PL}_{Z}$ każe zająć co najmniej sceptyczne stanowisko w stosunku do powszechnie wyrażanej w literaturze opinii, że osłabienie aktywności słonecznej stanowi przyczynę lub mogłoby być przyczyną ochłodzenia zim. Podobnie trudno przyjąć, żeby zmiany aktywności Słońca stanowiły główną i bezpośrednią energetyczną przyczynę długookresowych zmian temperatury powietrza. Zmiany, których absolutna amplituda mieści się $\mathrm{w}$ granicach $\pm 1,3 \mathrm{~W} \cdot \mathrm{m}^{-2}$ przy średniej $1360 \mathrm{~W} \cdot \mathrm{m}^{-2}$ są na tyle małe, że nie są fizycznie w stanie doprowadzić do zaistnienia takich różnic w bilansie cieplnym podłoża i atmosfery, aby spowodować różnice rzędu $1^{\circ} \mathrm{C}$ w temperaturze średniej rocznej, czy różnice rzędu $2-3^{\circ} \mathrm{C}$ $\mathrm{w}$ temperaturze zim.

To stwierdzenie nie wyklucza wpływu zmian aktywności słonecznej na klimat, ale realizującego się w innych, dłuższych skalach czasowych i zupełnie inną drogą na przykład poprzez wpływ zmiennej aktywności pola magnetycznego Słońca na strumień promieni kosmicznych dochodzących do Ziemi, a następnie, poprzez zmiany liczby jąder kondensacji, na zmiany zachmurzenia, które modulują natężenie strumienia promieniowania słonecznego dochodzącego do podłoża (Svensmark i Friis-Christensen 1997).

Niezależnie od stanowiska autorów tej pracy w podniesionej kwestii trzeba stwierdzić, że przebieg temperatury obszarowej zim w Polsce nie stanowi argumentu popierającego tezę, że zmiany aktywności Słońca są lub mogą być przyczyną występującej w tym przebiegu zmienności. Nawet jeśli przyjmie się wspomnianą hipotezę Svensmarka i Friis-Christensena (1997) za prawdziwą, nie znajduje się zgodności czasowej przebiegu temperatury zim w Polsce ze zmiennością aktywności słonecznej. Podobnie nie znajduje się w przebiegu temperatury zim w Polsce potwierdzenia argumentów wskazujących na to, że wybuchy wulkaniczne stanowią czy mogą stanowić przyczynę spadków temperatury powietrza w okresach zimowych. 


\section{Literatura}

Atlas klimatyczny Polski, Częsé tabelaryczna, zeszyt 2a. Temperatura powietrza, IMGW, Wydawnictwa Komunikacji i Łączności, Warszawa.

Balmaceda L., Kirvova N.A., Solanki S.K., 2007, Reconstruction of solar irradiance using the Group sunspot number, Advances in Space Research, 40, 986-989, DOI: 1016/j.asr.2007.02.077.

Bjerknes J., 1965, Atmosphere-ocean interaction during the 'Little Ice Age' [w:] WMO-IUGG Symposium on Research and Devolopment Aspects of Long-Range Forecasting, WMO-No.162, Technical Note, No. 66, Geneva, 77-88.

Bradley R.S., 1988, The explosive volcanic eruption signal in northern hemispere continental temperature records, Climatic Change, 12 (3), 221-243.

Brazdil R., Pfister C., Wanner H., von Storch H., Luterbacher J., 2005, Historical climatology in Europe - the State of the Art, Climatic Change, 70, 363-430. DOI: 1007/s10584-005-5924-1.

Brazdil R., Dobrovolny P., 2010, Historical climate in Central Europe during the last 500 years [w:] R. Przybylak, J. Majorowicz, R. Brazdil, M. Kejna (red.), The Polish climate in the European context, Springer, Dordrecht, Heidelberg, London, New York, 41-70.

Breitenmoser P., Beer J., Brönnimann S., Frank D., Steinhilber F., Wanner H., 2012, Solar and volcanic fingerprints in tree-ring chronologies over the past 2000 years, Palaeogeography, Palaeoclimatology, Palaeoecology, 313-314, 127-139. DOI: 10.1016/j.palaeo.2011.10. 014.

Briffa K.R., Osborn T.J., 2002, Blowing hot and cold, Science, 295 (5563), 2227-2228, DOI: 10.1126/science.1069486.

Bryś K., Bryś T., 2010, Reconstruction of the 217-year (1791-2007) Wroctaw air temperature and precipitation series, Bulletin of Geography, Physical Geography, Series 3, 121-171. DOI: http://dx.doi.org/10.2478/2332.

Crowley T.J., Zielinski G., Vinther B., Udisti R., Kreutz K., Cole-Dai J., Castellano E., 2008, Vocanism and the Little Ice Age, PAGES News, 16 (2), 22-23.

Degirmendžić J., 2003, Sezonowe zmiany przestrzennej struktury adwekcji ciepta i chtodu na powierzchni izobarycznej 850 hPa nad Polskq, Czasopismo Geograficzne, 74 (1-2), 107-117.

Dobrovolny P., Brazdil R., Kotyza O., Valašek H., 2010, Extreme summer and winter temperatures in the Czech Lands after A.D. 1500 and their Central European context, Geografie, 115 (3), 266-283.

Eriksson C., Omstedt A., Overland J.E., Percival D.B., Mofjeld H.O., 2007, Characterizing the European sub-arctic winter climate since 1500 using ice, temperature, and atmospheric circulation time series, Journal of Climate, 20 (21), 5316-5334, DOI: 10.1175/2007JCLI1461.1.

Fischer E,M., Luterbacher J., Zorita E., Tett S.F.B., Casty C., Wanner H., 2007, European climate response to tropical volcanic eruptions over the last half millennium, Geophysical Research Letters, 34, L05707, DOI: 10.1029/2006GL027992.

Gao C.C., Robock A., Ammann C., 2008, Volcanic forcing of climate over the past 1500 years: An improved ice core-based index for climate models, Journal of Geophysical Research - Atmospheres, 113, DOI:10.1029/2008JD010239. 
Graft H.-F., Kirchner I., Robock A., Schult I., 1993, Pinatubo eruption winter climate effects: model versus observations, Climate Dynamics, 9 (2), 81-93.

Groisman P.Ya., 1992, Possible regional climate consequences of the Pinatubo eruption: A empirical approach, Gerophysical Research Letters, 19 (15), 1603-1606. DOI: 10.1029/92GL01474.

Hildreth W., Fierstein J., 2012, The Novarupta-Katmai eruption of 1912 - largest eruption of the twentieth century; centennial perspectives, US Geological Survey Professional Paper 1791 (https://pubs.usgs.gov/pp/1791/ dostęp:?).

Hurrell J.W., 1995, Decadal trends in the North Atlantic Oscillation and relationship to regional temperature and precipitation, Science, 296 (5224), 676-679.

Jevrejeva S., 2001, Severity of winter seasons in the northern Baltic Sea between 1529 and 1990: reconstruction and analysis, Climate Research, 17 (1), 55-62.

Jones P.D., Jonsson T., Wheeler D., 1997, Extension to the North Atlantic Oscillation using early instrumental pressure observations from Gibraltar and south-west Iceland, International Journal of Climatology, 17 (13), 1433-1450.

Karl T.R., Trenberth K.E., 2003, Modern global climate change, Science, 302 (5651); 1719-1723. DOI: $10.1126 /$ science.1090228.

Keigwin L.D., 1996, The Little Ice Age and Medieval Warm Period in the Sargasso Sea, Science, 274 (5292), 1504-1507, DOI: 10.1126/science.274.5292.1504.

Koslowski G., Glaser R., 1995, Reconstruction of the winter severity index since 1701 in the western Baltic, Climatic Change, 31 (1), 79-98.

Koslowski G., Glaser R., 1999, Variations in reconstructed winter severity in the western Baltic from 1501 to 1995, and their implications from the North Atlantic Oscillation, Climatic Change, 41 (2), 175-191.

Kożuchowski K. (red.), 1990, Materiaty do poznania historii klimatu w okresie obserwacji instrumentalnych, Wydawnictwo Uniwersytetu Łódzkiego, Łódź.

Kożuchowski K., 1994, Tendencje i wahania okresowe zlodzenia Battyku (1720-1992), Rozprawy i Studia Uniwersytetu Szczecińskiego, 152, 159-169.

Kożuchowski K. (red.), 2000, Pory roku w Polsce; sezonowe zmiany w środowisku a wieloletnie tendencje klimatyczne, Zakład Dynamiki Środowiska i Bioklimatologii Uniwersytetu Łódzkiego, Łódź.

Kożuchowski K., 2003, Cyrkulacyjne czynniki klimatu Polski, Czasopismo Geograficzne, 74 (1-2), 93-105.

Kożuchowski K., 2004, Cyrkulacja atmosferyczna nad Polskq i jej wptyw na warunki klimatyczne [w:] K. Kozuchowski (red.), Skala, uwarunkowania i perspektywy wspótczesnych zmian klimatycznych w Polsce, Wydawnictwo „Biblioteka”, Łódź, 69-87.

Kożuchowski K., 2011, Klimat Polski. Nowe spojrzenie, PWN, Warszawa.

Kożuchowski K., Żmudzka E., 2003, 100-year series of areally averaged temperatures and precipitation totals in Poland, Acta Universitatis Wratislaviensis, No. 2542, Studia Geograficzne, $75,116-122$. 
Krivova N.A., Balmaceda L., Solanki S.K., 2007, Reconstruction of solar total irradiance since 1700 from the surface magnetic flux, Astronomy \& Astrophysics, 467, 335-346. DOI: 10.1051/00046361:20066725.

Lamb H.H., 1964, Climatic changes and variations in the atmospheric and ocean circulations, Geologische Rudschau, 54, 486-504.

Lehmann A., Getzlaff K., Harlaß J., 2011, Detailed assessment of climate variability in the Baltic Sea sea for the period 1958 to 2009, Climate Research, 46, 185-196, DOI: 10.3354/cr00876.

Lorenc H., 2000, Studia nad 220-letniq (1779-1998) seriq temperatury powietræa w Warswawie oraw ocena jej wiekowej tendencji, Materiały Badawcze, Seria: Meteorologia, 31, IMGW, Warszawa.

Luterbacher J., Dietrich D., Xoplaki E., Grosejan M., Wanner H. 2004, European seasonal and annual temperature variability, trends and extremes since 1500, Science, 303 (5663), 1499-1503.

Luterbacher J., Dietrich D., Xoplaki E., Grosejan M., Wanner H. 2006, European Seasonal Temperature Reconstructions. IGBP PAGES/World Data Center for Paleoclimatology, Data Contribution Series \# 2006-060. NOAA/NCDC Paleoclimatology Program, Boulder CO, USA.

Luterbacher J., Schmutz C., Gyalistras G., Xoplaki E., Wanner H., 1999, Reconstruction of monthly NAO and EU indices back to AD 1675, Geophysical Research Letters, 26 (17), 2745-2748.

Luterbacher J., Xoplaki E., Küttel M., Zorita E., Gonzales-Rouco J.F., Jones P.D., Stössel M., Rutishauser T., Wanner H., Wibig J., Przybylak R., 2010, Climate change in Poland in the past centuries and its relationship to European climate: Evidence from reconstructions and coupled climate models [w:] R. Przybylak, J. Majorowicz, R. Brazdil, M. Kejna (red.), The Polish climate in the European context, Springer, Dordrecht, Heidelberg, London, New York, 3-39.

Luterbacher J., Pfister C., 2005, The year without a summer, Nature Geoscience, 8, 246-248. DOI: $10.38 /$ ngeo2404.

Manley G., 1974, Central England temperatures: montly means 1659 to 1973, Quarterly Journal of the Royal Meteorological Society, 100, 389-405.

Mann M.E., Bradley R.S., Hughes M.K., 1998, Global-scale temperature patterns and climate forcing over the past six centuries, Nature, 392, 779-787, DOI:10.1038/33859.

Mann M. E., Zhang Z., Rutherford S., Bradley R.S., Hughes M.K., Shindell D., Ammann C., Faluvegi G., Ni F., 2009, Global signatures and dynamical origins of the Little Ice Age and Medieval Climate Anomaly, Science, 326 (5957), 1256-1260.

Marsz A.A., 2004, O momencie i procesach prowadzacych do końca Matej Epoki Lodowej, Prace Geograficzne, IGiPZ PAN, 200, 249-263.

Marsz A.A., 2006, W sprawie niektórych interpretacji skutków dziatania Oscylacji Pótnocnego Atlantyku (NAO), Czasopismo Geograficzne, 77 (3), 220-225.

Marsz A., 2008, W sprawie genezy Oscylacji Pótnocnoatlantyckiej, Przegląd Geofizyczny, 53 (1), $3-26$.

Marsz A., Styszyńska A., 2005, Cyrkulacyjne wwarunkowania ekstremalnego zlodzenia Battyku [w:] E. Bogdanowicz, U. Kossowska-Cezak i J. Szkutnicki (red.), Ekstremalne wjawiska hydrologiczne i meteorologiczne, Wydawnictwo IMGW, Warszawa, 429-440. 
Niedźwiedź T., 2004, Rekonstrukcja warunków termicznych lata w Tatrach od 1550 roku, Prace Geograficzne, 197, 57-88.

Niedźwiedź T., Glaser R., Hansson D., Helama S., Klimenko V., Łupikasza E., Małarzewski Ł., Nordli Ø., Przybylak R., Reman D., Solomina O., 2015, The historical time frame (Past 1000 Years) [w:] The BACC II. Second assessment of climate change for the Baltic Sea basin, Regional Climate Studies, 51-65. DOI 10.1007/978-3-319-16006-1_3.

Obrębska-Starklowa B., 1997a, Dylematy zwiqzane z badaniami klimatu matego glacjatu w skali globalnej [w:] J. Trepińska (red.), Wahania klimatu w Krakowie (1792-1995), Instytut Geografii Uniwersytetu Jagiellońskiego, Kraków, 191-198.

Obrębska-Starklowa B., 1997b, Wspótcæesne poglady na zmiany klimatyczne w Europie w okresie schytku matego glacjatu [w:] J. Trepińska (red.), Wahania klimatu w Krakowie (1792-1995), Instytut Geografii Uniwersytetu Jagiellońskiego, Kraków, 163-190.

Omstedt A., Chen D., 2001, Influence of atmospheric circulation to the maximum ice extent in the Baltic Sea, Journal of Geophysical Research, 106, C3, 4493-4500.

Omstedt A., Pettersen Ch., Rodhe J., Winsor P., 2004, Baltic Sea climate: 200 yr of data on air temperature, sea level variation, ice cover, and atmospheric circulation, Climate Research, 25, 205-216.

Osborn T.J., Jones P.D., 2014, The CRUTEM4 land-surface air temperature dataset: construction, previous versions and dissemination via Google Earth, Earth System Science Data, 6, 61-68, DOI: 10.5194/essd-6-61-2014.

Parker D., Horton B., 2005, Uncertainties in central England temperature 1878-2003 and some improvements to the maximum and minimum series, International Journal of Climatology, 25, 1173-1188. DOI: 10.1002/joc.1190.

Przybylak R., 2006, Zmiany klimatu Polski w ostatnich stuleciach [w:] M. Gutry-Korycka, A. Kędziora, L. Starkel i L. Ryszkowski (red.), Dtugookresowe przemiany krajobrazu Polski w wyniku zmian klimatu $i$ u:ytkowania siemi, Komitet Narodowy IGBP i Zakład Badań Środowiska Rolniczego i Leśnego PAN, Poznań, 29-47.

Przybylak R., 2008, Zmiany klimatu Polski i Europy w ostatnich stuleciach, Kosmos, 57 (3-4), 195-208.

Przybylak R., 2016, Poland's climate in the last millennium [w:] Oxford Research Encyclopedia, Climate Science, Oxford University Press USA, 36 pp. DOI: 10.1093/acrefore/9780190228620.013.2.

Przybylak R., Filipiak J., Oliński P., 2014, Obserwacje meteorologiczne Gottrieda Reygera w Gdańsku w latach 1722-1769 i ich przydatność do badań zmian klimatu, Przegląd Naukowy - Inżynieria i Kształtowanie Środowiska, 23 (4), 360-375.

Przybylak R., Majorowicz J., Wójcik G., 2001, Zmiany temperatury powietræa i opadów atmosferycznych w Polsce w okresie XVI-XX wieku, Prace i Studia Geograficzne, 29, 79-92.

Przybylak R., Majorowicz J., Wójcik G., Zielski A., Chorążyczewski W., Marciniak K., Nowosad W., Oliński P., Syta K., 2005, Temperature changes in Poland from the $16^{\text {th }}$ to the $20^{\text {th }}$ Centuries, International Journal of Climatology, 25, 773-791, DOI: 10.1002/joc.1149. 
Przybylak R., Pospieszyńska A., Wyszyński P., Nowakowski M., 2014, Air temperature changes in Żagań (Poland) in the period from 1781 to 1792, International Journal of Climatology, 34, 2408-2426, DOI: 10.1002/joc.3847.

Przybylak R., Wójcik G., Marciniak K., 2003, Wptyw Oscylacji Pótnocnoatalantyckiej i Arktycznej na warunki termiczne chtodnej pory roku w Polsce w XVI-XX wiekach, Przegląd Geofizyczny, 48 (1-2), 61-74.

Przybylak R., Wójcik G., Marciniak K., Chorążyczewski W., Nowosad W., Oliński P., Syta K., 2004, Zmienność warunków termično-opadowych w Polsce w okresie 1501-1840 w świetle danych historycznych, Przegląd Geograficzny, 76 (1), 5-31.

Ribes J.C., Nesme-Ribes E., 1993, The solar sunspot cycle in the Maunder minimum AD 1645 to $A D$ 1715, Astronomy and Astrophysics, 276, 549-563.

Robock A., 2000, Volcanic eruptions and climate, Reviews of Geophysics, 32 (2), 191-219 (199RG000054).

Robock A., 2001, Volcanic eruption, Tambora [w:] T. Munn (red.), Encyclopedia of global environmental change, John Willey \& Sons, London, 737-738.

Robock A., Mao J., 1992, Winter warming from large volcanic eruptions, Geophysical Research Letters, 19 (24), 2405-2408.

Seinä A., Palosuo E., 1993, Itämeren suurimpien vuotuisten jääpeitteen laajuksien luokittelu 1720-1992 - Risto Jurvan kokoaman aineiston 1720-1951 ja Merentutkimuslaitoksen jääpalvelun aineiston vuosilta 1952-1992 mukaan [Abstract: The classification of the maximum annual extent of ice cover in the Baltic Sea 1720-1992. Based on the material collected by Risto Jurva (winters 1720-1951) and the material of the ice service of the Finnish Institute of Marine Research (winters 1952-1992)], Meri, 20, 1-20.

Seinä A., Palosuo E., 1996, The classification of the maximum annual extent of ice cover in the Baltic Sea 1720-1995, Meri, 27 - Report Series of the Finnish Institute of Marine Research, No 27, 79-91.

van der Schrier G., Barkmeijer J., 2005, Bjerknes' hypotesis on the coldness during AD 1790-1820 revisited, Climate Dynamics, 24, 355-371, DOI 10.1007/s00382-004-0506-x.

van der Schrier G., Weber S.L., 2010, The Gulf Stream and Atlantic sea-surface temperatures in AD 1790-1825, International Journal of Climatology, 30, 1747-1763. DOI: 10.1002/joc.2027.

Steinhilber F., Beer J., 2011, Solar activity - the past 1200 years, PAGES news, 19 (1), 5-6.

Styszyńska A., 2010, Zlodzenie Battyku a temperatura w Polsce [w:] E. Bednorz (red.), Klimat Polski na tle klimatu Europy. Warunki termiczne i opadowe, Bogucki Wydawnictwo Naukowe, Poznań, 95-105.

Svensmark H., Friis-Christensen E., 1997, Variation of cosmic ray flux and global cloud coveragea missing link in solar-climate relationshipss, Journal of Atmospheric and Solar-Terrestrial Physics, 59 (11), 1225-1232.

Swingedouw D., Mignot J., Ortega P., Khodri M., Menegoz M., Cassou C., Hanquiez V., 2017, Impact of explosive volcanic eruptions on the main climate variability modes, Global and Planetary Change, 150, 24-45. http://dx.doi.org/10.1016/j.gloplacha. 2017.01.006. 
Tarand A., Nordli P.Ø., 2001, The Tallinn temperature series reconstructed back half a millennium by use of proxy data, Climatic Change, 48 (1), 189-199.

Tinz B., 1996, On the relation between annual maximum of ice cover in the Baltic Sea and sea level pressure as well as air temperature field, Geophysica, 32, 319-341.

Varenholt F., Lüning S., 2012, Die kalte Sone. Warum die Klimatastophe nicht stattfindet, Hoffmann und Campe Verlag, Hamburg.

Vihma T., Haapala J., 2009, Geophysics of sea ice in the Baltic Sea; A review, Progress in Oceanography, 80 (3), 129-148. doi: 10.1016/j.pocean.2009.02.002.

Waple A., Mann M., Bradley R., 2002, Long-term patterns of solar irradiance forcing in model experiments and proxy based surface temperature reconstructions, Climate Dynamics, 18 (7), 563-578.

Xoplaki E., Luterbacher J., Paeth H., Dietrich D., Steiner N., Grosejan M., Wanner H., 2005, European spring and autumun temperature variability and change of extremes over the last half millennium, Geophysical Research Letters, 32, L15713. doi: 10.1029/2005GL023424.

Andrzej A. Marsz

Polskie Towarzystwo Geofizyczne, Oddziat Battycki, aamarsw127@gmail.com

Anna Styszyńska

Politechnika Gdańska

Katedra Urbanistyki i Planowania Regionalnego

ul. Narutowicza 11/12, 80-233 Gdańsk,

anna.styszynska@pg.edu.pl 


\section{ZAŁĄCZNIKI}

Załącznik 1.

Wartości średniej obszarowej temperatury $\left({ }^{\circ} \mathrm{C}\right)$ okresów zimowych (grudzień-marzec) w latach 1720-2015. Zima datowana jest na rok stycznia (np. zima 1939/40 datowana jest jako rok 1940). Wartości zrekonstruowane oznaczone pochylonym drukiem

Appendix 1.

Values of the mean area winter (Dec-Mar) temperature $\left({ }^{\circ} \mathrm{C}\right.$ ) in the years $1720-2015$. Winter is dated to January (e.g. winter 1939/40 dated as 1940). Reconstructed values marked in italics

\begin{tabular}{|c|c|c|c|c|c|c|c|c|c|c|}
\hline Rok & 0 & 1 & 2 & 3 & 4 & 5 & 6 & 7 & 8 & 9 \\
\hline 1720 & 0,29 & 0,37 & 0,57 & $-1,52$ & 1,13 & 0,89 & $-2,95$ & 0,63 & $-0,55$ & $-2,55$ \\
\hline 1730 & 0,94 & $-2,33$ & $-0,99$ & 1,50 & 0,71 & 1,11 & 0,54 & 1,34 & $-0,42$ & $-0,94$ \\
\hline 1740 & $-5,65$ & $-0,82$ & $-0,79$ & $-0,30$ & $-1,00$ & $-1,65$ & $-1,75$ & $-2,51$ & $-2,42$ & $-1,30$ \\
\hline 1750 & 0,57 & $-2,32$ & $-1,45$ & $-0,46$ & $-3,09$ & $-1,78$ & 0,30 & $-3,55$ & $-2,68$ & 1,45 \\
\hline 1760 & $-2,53$ & 0,96 & 0,71 & $-1,41$ & 0,25 & $-0,04$ & $-2,00$ & $-3,34$ & $-2,79$ & $-0,07$ \\
\hline 1770 & $-2,74$ & $-3,53$ & $-3,33$ & 0,59 & $-2,46$ & $-0,41$ & $-2,39$ & $-2,23$ & $-1,21$ & 0,36 \\
\hline 1780 & $-3,70$ & $-1,19$ & $-1,64$ & $-0,52$ & $-4,59$ & $-2,02$ & $-2,57$ & $-1,48$ & $-1,16$ & $-3,62$ \\
\hline 1790 & 0,37 & 1,26 & $-1,09$ & $-0,49$ & 0,23 & $-4,58$ & 1,95 & $-0,34$ & 0,63 & $-4,11$ \\
\hline 1800 & $-2,37$ & 0,50 & $-1,50$ & $-2,84$ & $-1,10$ & $-2,94$ & $-1,14$ & $-0,43$ & $-2,34$ & $-4,04$ \\
\hline 1810 & $-2,15$ & $-1,48$ & $-2,06$ & $-2,30$ & $-4,61$ & $-1,52$ & $-2,26$ & 0,69 & $-1,19$ & 1,02 \\
\hline 1820 & $-3,47$ & $-0,70$ & 1,10 & $-2,22$ & 0,61 & 0,77 & $-1,28$ & $-1,55$ & $-0,63$ & $-3,94$ \\
\hline 1830 & $-3,89$ & $-2,23$ & 0,26 & $-0,58$ & 0,46 & 0,50 & $-2,51$ & $-1,55$ & $-5,38$ & $-2,39$ \\
\hline 1840 & $-3,18$ & $-4,58$ & $-0,75$ & 0,74 & $-1,67$ & $-2,37$ & 0,65 & $-2,28$ & $-0,81$ & $-0,74$ \\
\hline 1850 & $-2,67$ & $-1,03$ & $-0,57$ & $-0,62$ & $-2,48$ & $-3,44$ & $-2,97$ & $-1,05$ & 0,27 & 0,92 \\
\hline 1860 & $-1,02$ & $-2,55$ & $-1,49$ & 1,19 & 0,27 & $-1,92$ & 1,37 & $-3,21$ & $-2,21$ & 1,46 \\
\hline 1870 & $-0,16$ & $-3,66$ & 0,82 & 1,00 & 1,73 & $-0,46$ & $-2,72$ & $-2,11$ & 1,26 & $-2,42$ \\
\hline 1880 & $-1,01$ & $-4,87$ & 1,28 & $-2,42$ & 0,93 & $-0,09$ & $-2,92$ & $-1,23$ & $-3,01$ & $-3,35$ \\
\hline 1890 & $-0,78$ & $-3,17$ & $-1,31$ & $-3,61$ & $-0,10$ & $-2,66$ & $-1,13$ & $-1,46$ & 1,34 & 0,05 \\
\hline 1900 & $-1,36$ & $-2,00$ & 0,32 & 0,02 & $-1,11$ & $-0,43$ & $-0,23$ & $-2,95$ & $-0,80$ & $-2,94$ \\
\hline 1910 & 1,33 & $-0,11$ & $-0,78$ & 0,82 & 0,74 & $-0,37$ & $-0,13$ & $-3,96$ & $-0,49$ & $-0,41$ \\
\hline 1920 & 0,50 & 0,96 & $-2,54$ & $-0,03$ & $-3,63$ & 1,23 & $-0,61$ & $-0,04$ & $-2,04$ & $-6,24$ \\
\hline 1930 & 0,91 & $-2,22$ & $-2,10$ & $-1,21$ & $-0,67$ & $-0,82$ & 0,91 & $-0,70$ & 0,77 & $-0,04$ \\
\hline 1940 & $-4,44$ & $-3,69$ & $-5,40$ & 0,39 & $-0,05$ & $-0,36$ & $-0,82$ & $-5,06$ & 0,23 & $-0,31$ \\
\hline 1950 & $-0,23$ & $-0,68$ & $-0,99$ & $-1,02$ & $-3,99$ & $-1,29$ & $-3,52$ & 0,85 & $-1,45$ & 0,63 \\
\hline 1960 & $-1,64$ & 1,48 & $-1,83$ & $-6,11$ & $-3,75$ & $-1,72$ & $-0,81$ & $-0,26$ & $-1,01$ & $-4,08$ \\
\hline 1970 & $-4,43$ & $-0,93$ & $-0,20$ & 0,46 & 1,05 & 2,23 & $-1,69$ & 0,21 & $-1,00$ & $-3,25$ \\
\hline 1980 & $-2,25$ & $-0,26$ & $-1,79$ & 1,22 & $-0,61$ & $-4,28$ & $-1,86$ & $-4,05$ & 0,54 & 2,71 \\
\hline 1990 & 3,35 & $-0,14$ & 0,61 & $-0,16$ & 1,44 & 1,38 & $-4,52$ & $-1,25$ & 1,35 & 0,19 \\
\hline 2000 & 1,29 & 0,75 & 1,03 & $-2,77$ & $-0,07$ & $-0,11$ & $-2,74$ & 3,27 & 2,00 & 0,07 \\
\hline 2010 & $-1,86$ & $-1,74$ & 0,04 & $-2,01$ & 2,31 & 2,05 & & & & \\
\hline
\end{tabular}


Załącznik 2.

Średnia dekadowa temperatura obszarowa zim (12-03) nad Polską $\left({ }^{\circ} \mathrm{C}\right)$ i dodatkowe informacje o zmienności temperatury zim $w$ danej dekadzie: $\sigma$ - odchylenie standardowe temperatury zim w danej dekadzie, min - najniższa temperatury zimy w danej dekadzie, max - najwyższa temperatura zimy w danej dekadzie, $\mathrm{PL}_{\mathrm{z}}>0$ - liczba zim o średniej dodatniej temperaturze w dekadzie, $\sigma$ (dek) - odchylenie standardowe temperatury zimy w danej dekadzie względem średniej dekadowej z okresu 1721-2010

Appendix 2.

Mean decade winter area temperature (Dec-Mar) over Poland $\left({ }^{\circ} \mathrm{C}\right.$ ) and additional information on winter temperature variability in a given decade: $\sigma$ - standard deviation of winter temperatures in a given decade, min - lowest winter temperature in given decade, max highest winter temperature in a given decade, $\mathrm{PL}_{Z}>0-$ number of winters with a positive mean temperature in a decade, $\sigma$ (dek)-standard deviation of winter temperature in a given decade versus the mean decade temperature from the period of 1721-2010

\begin{tabular}{|c|c|c|c|c|c|c|c|c|c|c|}
\hline & $01-10$ & $11-20$ & $21-30$ & $31-40$ & $41-50$ & $51-60$ & $61-70$ & $71-80$ & $81-90$ & $91-00$ \\
\hline \multicolumn{11}{|c|}{1700} \\
\hline średnia & - & - & $-0,304$ & $-0,515$ & $-1,196$ & $-1,610$ & $-1,047$ & $-1,831$ & $-1,842$ & $-0,890$ \\
\hline$\sigma$ & - & - & 1,52 & 2,18 & 0,99 & 1,59 & 1,60 & 1,59 & 1,45 & 2,19 \\
\hline $\min$ & - & - & $-2,952$ & $-5,653$ & $-2,510$ & $-3,555$ & $-3,327$ & $-3,704$ & $-4,588$ & $-4,589$ \\
\hline $\max$ & - & - & 1,124 & 1,496 & 0,569 & 1,499 & 0,956 & 0,591 & 0,369 & 1,954 \\
\hline $\mathrm{PL}_{z}>0$ & - & - & 6 & 5 & 1 & 2 & 3 & 2 & 1 & 4 \\
\hline$\sigma($ dek $)$ & & & 1,403 & 1,040 & $-0,133$ & $-0,845$ & 0,124 & $-1,225$ & $-1,244$ & 0,394 \\
\hline \multicolumn{11}{|c|}{1800} \\
\hline średnia & $-1,797$ & $-1,727$ & $-1,174$ & $-1,659$ & $-1,448$ & $-1,198$ & $-0,725$ & $-0,756$ & $-1,645$ & $-1,340$ \\
\hline$\sigma$ & 1,34 & 1,72 & 1,79 & 1,98 & 1,61 & 1,39 & 1,76 & 1,91 & 1,64 & 1,53 \\
\hline $\min$ & $-4,040$ & $-4,607$ & $-3,940$ & $-5,375$ & $-4,580$ & $-3,445$ & $-3,205$ & $-3,662$ & $-4,871$ & $-3,605$ \\
\hline $\max$ & 0,504 & 1,023 & 1,097 & 0,505 & 0,740 & 0,916 & 1,465 & 1,735 & 1,292 & 1,337 \\
\hline $\mathrm{PL}_{2}>0$ & 1 & 2 & 3 & 3 & 2 & 2 & 4 & 4 & 2 & 2 \\
\hline$\sigma(\mathrm{dek})$ & $-1,167$ & $-1,064$ & $-0,095$ & $-0,929$ & $-0,566$ & $-0,136$ & 0,678 & 0,625 & $-0,905$ & $-0,380$ \\
\hline \multicolumn{11}{|c|}{1900} \\
\hline średnia & $-0,880$ & $-0,420$ & $-1,204$ & $-1,051$ & $-1,529$ & $-1,310$ & $-2,253$ & $-0,536$ & $-0,503$ & 0,020 \\
\hline$\sigma$ & 1,40 & 1,36 & 2,40 & 1,58 & 2,26 & 1,53 & 2,89 & 1,63 & 2,58 & 1,82 \\
\hline $\min$ & $-2,960$ & $-3,962$ & $-6,235$ & $-4,435$ & $-5,400$ & $-3,985$ & $-6,105$ & $-3,249$ & $-4,280$ & $-4,524$ \\
\hline $\max$ & 1,325 & 0,815 & 1,225 & 0,910 & 0,385 & 0,852 & 1,475 & 2,233 & 3,352 & 1,442 \\
\hline $\mathrm{PL}_{2}>0$ & 3 & 3 & 3 & 2 & 2 & 2 & 1 & 4 & 4 & 6 \\
\hline$\sigma(\mathrm{dek})$ & 0,411 & 1,203 & $-0,146$ & 0,117 & $-0,706$ & $-0,380$ & $-1,952$ & 1,003 & 1,060 & 1,960 \\
\hline \multicolumn{11}{|c|}{2000} \\
\hline średnia & $-0,044$ & - & - & - & - & - & - & - & - & - \\
\hline$\sigma$ & 1,97 & - & - & - & - & - & - & - & - & - \\
\hline $\min$ & $-2,769$ & - & - & - & - & - & - & - & - & - \\
\hline $\max$ & 3,265 & - & - & - & - & - & - & - & - & - \\
\hline $\mathrm{PL}_{7}>0$ & 5 & - & - & - & - & - & - & - & - & - \\
\hline$\sigma($ dek $)$ & 1,850 & - & - & - & - & - & - & - & - & - \\
\hline
\end{tabular}

